\title{
Mirroring or Muscling: An Examination of State Class Action Appellate Rulemaking
}

\author{
Laura J. Hines*
}

\section{INTRODUCTION}

This Symposium focuses on the developments in aggregate litigation since Amchem Products, Inc. v. Windsor ${ }^{1}$ and Ortiz v. Fibreboard Corporation, ${ }^{2}$ the Supreme Court's prominent pair of mass tort class action cases decided in the last few years of the twentieth century. In the year between those high profile decisions interpreting Federal Rule 23, with far less fanfare or drama, the Court approved its first significant amendment to the federal class action rule in over thirty years, Rule 23(f). This article examines the impact of that long-awaited, yet modest, federal rule change on its state class action rule counterparts, part of a larger research project examining federal/state procedural dynamics and broader issues of tort reform.

Rule 23(f) grew out of the concern that lower court misinterpretations of Rule 23 too often escaped appellate review and correction due to the interlocutory nature of the class certification order. ${ }^{3}$

\footnotetext{
Professor, University of Kansas School of Law. I wish to thank Elizabeth Chamblee Burch, Howard Erichson, Steve Gensler, Linda Mullenix, Tom Willging, and Patrick Woolley for their excellent contributions to this Symposium, and for their helpful feedback on my work. I am also grateful for the assistance and encouragement of Laura Dooley, Bruce Kobayashi, Glenn Koppel, Larry Ribstein, Catherine Sharkey, and Ronen Avraham, who kindly provided me a preview version of the DSTLR3rd. My thanks must go out, as well, to Bridget Gavahan, Joey Moya, Richard Holme, Michael McCarthy, Jeff Feldman, and Rachel Yates, who graciously shared their state rulemaking expertise; Shane McCall, whose dedication to this Symposium paid off brilliantly; Dean Gail Agrawal, for her continued friendship and generosity; and David Cascio, Paul Lantis, Stephanie Lovett-Bowman, Brian Mulhern, Mindie Paget, Melissa Rogers, Michele Rutledge, and Ryan Schletzbaum, for their thoughtful and good-natured assistance. Finally, this article would not have been possible without the insightful comments and steadfast support of Chris Drahozal, the exceptional research and diligence of Chris Steadham, and the unflagging optimism and patience of Tim Davis.

1. 521 U.S. 591 (1997).

2. 527 U.S. 815 (1999).

3. See, e.g., FED. R. CIV. P. 23(f) advisory committee's note. The final judgment rule in federal courts, which generally does not permit litigants to appeal non-final orders until after a final judgment has been entered, created particularly risky predicaments for class litigants who believed Rule 23 had been wrongly applied by a district court: a rejected class plaintiff might lack sufficient
} 
Rule 23(f) authorized class litigants to seek discretionary appellate review of such orders without all of the stringent requirements of preexisting exceptions to the final judgment rule. ${ }^{4}$ While states have their own class action rules, and are not bound by any changes to the federal class action rule, they face many of the same controversies about the proper role and parameters of the class action. Indeed, prior to the adoption of Rule 23(f), a number of states already provided immediate access to appellate review of class certification decisions. ${ }^{5}$ The majority of states, however, provided limited avenues for class litigants to challenge certification decisions prior to Rule 23(f), particularly orders granting certification of a class action. ${ }^{6}$

In the decade after Rule 23(f), a number of states altered their existing appellate rules relating to interlocutory review of class certification orders. While the state rule changes did not always mirror the federal rule, they all moved in the same direction, acting to expand appellate access for class litigants. It is impossible to know, of course, exactly why each state did so or why other states have not. Scholars have examined the relationship between federal and state procedural rules through a variety of lenses, including the degree of uniformity, and how political, cultural, and judicial differences between federal and state courts may affect the policies and content of rulemaking. ${ }^{7}$ Building on that research, this Article explores two central hypotheses that may help explain what inspired state rulemaking bodies to amend their class action appeals rules.

First, given that a majority of states have adopted civil procedural rules based on the model of the federal rules, I consider whether states might have changed their class action appeals rules in an effort to continue their replication of the federal model. Second, I examine the

resources to pursue litigation on an individual basis, and a defendant confronting a certified class might feel pressured to settle rather than engage in protracted class litigation and a potentially crippling damages award at trial before appellate relief could be sought. See id.

4. See Michael E. Solimine \& Christine Oliver Hines, Deciding to Decide: Class Action Certification and Interlocutory Review by United States Courts of Appeals Under Rule 23(f), 41 WM. \& MARY L. REV. 1531, 1535-36 (2000).

5. See infra notes $71-72$ and accompanying text.

6. See infra notes 75-76 and accompanying text.

7. See, e.g., Deborah R. Hensler et Al., Class ACtion Dilemmas: Pursuing PubliC GOALS FOR PRIVATE GAINS, 15-22 (RAND Inst. for Civil Justice 2000); Glenn S. Koppel, Toward a New Federalism in State Civil Justice: Developing a Uniform Code of State Civil Procedure Through a Collaborative Rule-Making Process, 58 VAND. L. REV. 1167, 1194-1201 (2005); Jonathan R. Macey, Judicial Preferences, Public Choice, and the Rules of Procedure, 23 J. LEGAL STUD. 627 (1994); John B. Oakley, A Fresh Look at the Federal Rules in State Courts, 3 NEV. L.J. 354 (2003); Stephen N. Subrin, Uniformity in Procedural Rules and the Attributes of a Sound Procedural System: The Case for Presumptive Limits, 49 ALA. L. REV. 79 (1997). 
role interest groups might have played in the state rulemaking processes. To the extent such groups perceived that rules expanding access to appellate courts more often work to the strategic advantage of those opposed to class actions, one would expect to find higher adoption rates of Rule 23(f) equivalent rules in states where defendant-oriented interest groups have incentives to influence the rulemaking process. To test these two hypotheses for state rulemaking conduct, which I refer to as the Replica Theory and the Interest Group Theory, I consider several measures for each theory, attempting to determine how well these theories explain which states altered their class action appeals rules.

Subject to several important limitations, I posit a few tentative conclusions about state rulemaking behavior post-Rule 23(f). I found some clear evidence of a replica effect: following Rule 23(f), states that more closely patterned their rules after the federal rules ("replica states") amended their rules to expand class litigant appellate access at higher rates than states less inclined to mirror federal rules in the first instance. But the high rate of expanded class appeals rules among non-replica states both pre- and post-Rule 23(f) clearly suggests the presence of significant influences other than Rule 23(f) itself.

The data suggest that interest group pressures also likely played a role in some state rulemaking conduct: highly populous states, states with relatively large numbers of Fortune 500 corporate headquarters, and states with elevated levels of perceived class action activity were more likely to have allowed expanded class action appeals even before Rule 23(f), and appear to have been more amenable to amending their class action rules post-Rule 23(f) to provide greater levels of appellate access. But the flexing of interest group muscles does not wholly explain state class action rulemaking conduct in this era, some of which remains apparently attributable to a Replica Theory effect.

These conclusions, of course, are subject to a number of important qualifications. Those qualifications include: first, only a relatively small number of states changed their class action rules. The limited sample sizes involved do not permit statistical testing, so that at least some of the effects observed may be due to chance. Second, I did not conduct any sort of regression analysis, although I do acknowledge and attempt to control for some confounding factors in my analysis. The difficulty of controlling for confounding factors likewise counsels caution in drawing definitive conclusions as to the precise relationships involved. Third, as noted above, this paper is only the first part of a broader and ongoing research project. Thus, the conclusions I reach here necessarily are preliminary and provisional. 
I begin in Part II by briefly describing the two recent federal procedural developments that may have played important roles in inspiring the state class action appellate rule changes we have witnessed in the last decade or so, Rule 23(f) and the Class Action Fairness Act. Part III presents a state-by-state analysis of the timing, nature, and context of each state's decision to alter its rules to effectively expand opportunities for appealing class certification orders. Finally, in Part IV, I examine several empirical measures in order to test the extent to which state rulemaking conduct may be explained by state mirroring of federal rules or the muscling influence of interest groups.

\section{BACKGROUND: FEDERAL RULE 23(F) AND CAFA}

\section{A. Federal Rule 23(f)}

Federal Rule 23(f), which became effective in December of 1998, represented the first major amendment to the federal class action rule since its massive overhaul in $1966 .^{8}$ Although the Advisory Committee on Civil Rules initially considered far more extensive revisions, ${ }^{9}$ the Rule 23 revision process of the 1990s culminated with 23(f) as the only amendment finally adopted by the Judicial Conference and the Supreme Court. ${ }^{10}$ The provision, authorized by 28 U.S.C. $§ 1292(\mathrm{e}),{ }^{11}$ permits an aggrieved class action litigant to request that the relevant federal court of appeals exercise its discretion to accept an interlocutory appeal of a class certification order. $^{12}$

Prior to Rule 23(f), plaintiffs denied the right to proceed on a class basis and defendants faced with a certified class ordinarily faced slim prospects of interlocutory appellate review. In 1979, the Supreme Court eliminated both the death knell exception to the final judgment rule and

8. See 7A Charles Alan Wright et al., Federal Practice and Procedure Civil $\S$ 1753.1 (3d ed. (2009)).

9. See Linda S. Mullenix, The Constitutionality of the Proposed Rule 23 Class Action Amendments, 39 ARIz. L. REV. 615, 619-24 (1997) (reviewing other proposed class action rule amendments).

10. The Advisory Committee took up Rule 23 again in 2001, resulting in a number of amendments adopted in 2003 dealing with Rule 23(c), (d), (e) and new provisions (g) and (h).

11. 28 U.S.C. § 1292(e) (2006); see infra notes 18-40.

12. In its entirety, Rule 23(f) reads:

A court of appeals may permit an appeal from an order granting or denying class action certification under this rule if a petition for permission to appeal is filed with the circuit clerk within 14 days after the order is entered. An appeal does not stay proceedings in the district court unless the district judge or the court of appeals so orders.

FED. R. CIV. P. 23(f). 
the collateral order doctrine as appellate options for orders denying class certification. $^{13}$ The remaining avenues for interlocutory appellate review, a writ of mandamus ${ }^{14}$ or dual certification of the order by the district court and court of appeals pursuant to the stringent terms of 28 U.S.C. \$1292(b), ${ }^{15}$ proved only infrequently (and unreliably) available to class action litigants attempting to challenge class certification decisions by the trial court on an interlocutory basis. ${ }^{16}$

Rule 23(f) has a long, albeit rather low-profile back story, as a persistent also-ran in a wide-ranging set of procedural reforms dating back at least to 1986, when the ABA released its Report and Recommendations of the Special Committee on Class Action Improvements. $^{17}$ That Report noted that "[p]revious efforts at meaningful reform of the class action have encountered stiff opposition and none has commanded the consensus necessary to achieve adoption."18 Nonetheless, the ABA Committee's five-year study concluded with six recommended class action reforms, the last of which urged Congress to amend 28 U.S.C. § 1292 to expressly provide federal

13. Coopers \& Lybrand v. Livesay, 437 U.S. 463, 469, 476 (1978). The death knell exception persisted, however, in several states that declined to follow the Supreme Court's reasoning in Coopers. See, e.g., Perry v. Cullipher, 318 S.E.2d 354, 355-56 (N.C. Ct. App. 1984); Alessandro v. State Farm Mut. Auto. Ins. Co., 409 A.2d 347, 350-51 (Pa. 1979); Mitchem v. Melton, 277 S.E.2d 895, 901 (W. Va. 1981).

14. See, e.g., In re Am. Med. Sys., Inc., 75 F.3d 1069, 1090 (6th Cir. 1996) (granting writ of mandamus to review certification of class certification order); In re Rhone-Poulenc Rorer, Inc., 51 F.3d 1293, 1304 (7th Cir. 1995) (same); In re Fibreboard Corp., 893 F.2d 706, 712 (5th Cir. 1990) (same).

15. Section 1292(b) not only requires litigants to seek permission to file an interlocutory appeal from both the district court and the trial court, it also demands determinations that the order "involves a controlling question of law as to which there is substantial ground for difference of opinion and that an immediate appeal from the order may materially advance the ultimate termination of the litigation.” 28 U.S.C. §1292(b) (2006); see, e.g., Valentino v. Carter-Wallace, Inc., 97 F.3d 1227 (9th Cir.1996) (agreeing to hear interlocutory appeal of class certification order certified by district court pursuant to § 1292(b)); In re School Asbestos Litig., 789 F.2d 996 (3rd Cir. 1986) (same).

16. See Solimine \& Hines, supra note 4, at 1535-36 (before Rule 23(f), it was "extremely difficult for litigants to gain an immediate appeal of a class certification order”); Thomas E. Willging, Laural L. Hooper, \& Robert J. Niemic, An Empirical Analysis of Rule 23 to Address the Rulemaking Challenges, 71 N.Y.U. L. REV. 74, 167 (1996) (observing that, with few exceptions, class certification orders rarely qualified for either $\S 1292$ (b) or a successful writ of mandamus). See generally Melissa A. Waters, Common Law Courts in an Age of Equity Procedure: Redefining Appellate Review for the Mass Tort Era, 80 N.C. L. REV. 527, 555-59 (2002) (summarizing and identifying inadequacies of the exceptions to the final judgment rule in the mass tort context).

17. Am. Bar Ass'n Section of Litig., Report and Recommendations of the Special Committee on Class Action Improvements, 110 F.R.D. 195 (1986) [hereinafter ABA Report]. The Special Committee, made up of attorneys with class action and public interest perspectives as well as two federal judges, began its deliberations in 1981. Id. at 196.

18. Id. at 196-97. 
appellate courts with the unilateral discretionary authority to hear appeals from both grants and denials of class certification motions. ${ }^{19}$

The ABA Committee's suggested amendment to $\$ 1292$ not only closely resembles the ultimate language of Rule 23(f), which became effective twelve years later, ${ }^{20}$ but its reasoning and contemplated goals for the expansion of available interlocutory appellate authority foreshadow Rule 23(f)'s Advisory Committee's Note. ${ }^{21}$ Describing the "unique public importance" of this "critical ruling" in class action lawsuits, the ABA Committee explained that immediate discretionary appeal of class certification orders would help to address the appellate dilemmas presented to both a rejected class representative and a defendant confronting a certified class. The defeated individual plaintiff "must abandon his efforts to represent the alleged class or incur expenses wholly disproportionate to his individual recovery in order to secure appellate review of the certification order,"22 while a defendant faces "potentially ruinous liability and may be forced to settle a case rather than run the economic risk of trial in order to secure review of the certification ruling." ${ }^{23}$ In either event, erroneous class certification rulings may effectively escape appellate review. The Committee's recommended amendment to Section 1292, therefore, would create a new provision expressly permitting class litigants to apply directly to the court of appeals for discretionary review of certification orders.

The idea of amending Section 1292 to expand appellate authority over interlocutory orders, although not directed specifically at class certification orders, was also included in the wide-ranging, one hundred and eighty-eight page report released by the Federal Courts Study Committee ("FCSC") in 1990. ${ }^{24}$ The "little noticed and seemingly

19. Id. at 210-11. The ABA Committee also recommended consolidating all of Rule 23(b)'s provisions into a single standard applicable to all class actions, modifying the notice and exclusion requirements of Rule 23(c)(2), clarifying the interaction between class certification motions and dispositive motions under Rules 12 and 56, and adopting amendments designed to facilitate early judicial management and coordination of class actions. See id. at 198-210.

20. See FED. R. CIV. P. 23(f). The ABA Committee's proposal included, for example, a ten-day time period for appeals from district court certification orders and a provision that "an appeal hereunder shall not stay proceedings in the district court unless the district court or the Court of Appeals or a judge thereof shall so order.” ABA Report, supra note 17, at 210.

21. Compare FED. R. CIV. P. 23(f) advisory committee's note with ABA Report, supra note 17, at 210-11. The ABA Committee concluded with a familiar anticipation that appellate courts would "rare[ly]" accept review of such orders, but the "potential for immediate interlocutory review will encourage compliance with the certification procedure and will afford an opportunity for the prompt correction of error with resulting litigation economies.” ABA Report, supra note 17, at 211.

22. ABA Report, supra note 17 , at 210.

23. Id. at 211; see also Willging, Hooper, \& Niemic, supra note 16, at 174.

24. Judicial CONFERENCE OF THE United StATES, REPORT OF THE FEDERAL COURTS STUDY 
innocuous”25 appellate procedure recommendations by the FCSC sought to provide the Supreme Court the rulemaking authority to "add to-but not subtract from - the list of categories of interlocutory appeal." ${ }^{26}$ In 1992, Congress implemented that recommendation, along with a host of higher profile FCSC provisions, amending Section 1292 to authorize rule-based interlocutory appeals. ${ }^{27}$ As one scholar observed, the appeals provisions "were treated as noncontroversial by Congress." 28 The amendment laid the foundation for the only exercise of this new rulemaking authority thus far, Rule 23(f).

In 1991, the Advisory Committee on Civil Rules, at the request of the Judicial Conference, embarked on what would become a seven-year odyssey of Rule 23 rulemaking, considering a number of provocative and innovative amendments to the class action rule. ${ }^{29}$ From the very beginning of this process, "the Advisory Committee recognized the need to provide some means of interlocutory review of class certification orders," 30 and every proposal the Committee considered throughout the 1990s contained a provision roughly approximating the ultimately adopted final version of Rule 23(f). ${ }^{31}$ Indeed, after much debate and deliberation, the more far-reaching and ambitious proposals were "withdrawn or shelved,"32 while Rule 23(f) emerged as the sole successful class action amendment.

Although it may have lacked the drama of other contemporary class action proposals, Rule 23(f) nonetheless faced "a strident and sizeable" opposition among those who contributed to the public debate during its

COMMITTEe 95-96 (1990) [hereinafter FEDERAL COURTS STUdy COMMITTEE RePORT].

25. See Robert J. Martineau, Defining Finality and Appealability by Court Rule: Right Problem, Wrong Solution, 54 U. PITT. L. REV. 717, 718 (1992).

26. FEDERAL COURTS STUDY COMMITTEE REPORT, supra note 24, at 96.

27. See Federal Courts Administration Act of 1992, Pub. L. No. 102-572, § 101, 106 Stat. 4506, 4506 (1992) (codified in 28 U.S.C. § 1292(e) (1994)).

28. See Martineau, supra note 25, at 726.

29. See generally Mullenix, supra note 9; Willging, Hooper, \& Niemic, supra note 16

30. Linda S. Mullenix, Some Joy in Whoville: Rule 23(f), a Good Rulemaking, 69 TENN. L. REv. 97, 102 (2001); see also Blair v. Equifax Check Serv., Inc., 181 F.3d 832, 833-34 (7th Cir. 1999) ("We keep in mind the reasons Rule 23(f) came into being. ... By the end of the case it will be too late-if indeed the case has an ending that is subject to appellate review.").

31. Memorandum from Paul V. Niemeyer, Chair, Advisory Comm. on Civil Rules to the Hon. Alicemarie H. Stotler, Chair, Standing Comm. on Rules of Practice and Procedure, Re: Report of the Advisory Committee on Civil Rules 2-3 (May 21, 1997) [hereinafter Report of the Advisory Committee on Civil Rules] (on file with author) ("This interlocutory appeal provision has persisted virtually unchanged through the many alternative Rule 23 drafts that have been prepared by the Advisory Committee over the last six years.”); Solimine \& Hines, supra note 4, at 1564.

32. See Solimine \& Hines, supra note 4, at 1564; see also Mullenix, supra note 30, at 102-03 (describing the history of Rule 23(f)). 
notice and comment period. ${ }^{33}$ Objectors contended, inter alia, that the seemingly non-partisan rule would in practice benefit defendants more than plaintiffs. ${ }^{34}$ For example, the Advisory Committee summarized one commenter as declaring that "[o]verwhelmingly plaintiffs oppose and defendants support. This is clear proof that this proposal favors defendants." "35 As another objector argued, "the rule as written does little to advance a plaintiff's situation, but does provide significant dilatory opportunities for defendants." 36

In 1997, the Advisory Committee approved Rule 23(f), however, with the federal judiciary's firmly stated confidence that appellate courts would exercise their new authority promptly and with due care to prevent abuses of the provision. ${ }^{37}$ After winding its way successfully through the Standing Committee, the Judicial Conference, and the Supreme Court, ${ }^{38}$

33. Mullenix, supra note 30, at 104; see also id. at 103 (observing that "proposed Rule 23(f) generated more opposition than support”). Although the proposal's supporters welcomed the increased opportunity to seek interlocutory appeals, many urged the committee to delete proposed language in the Advisory Committee's Note suggesting that appeals should be granted "with restraint," and also recommended that the rule include an automatic stay provision. See, e.g., FED. R. CIV. P. 23(f) app. B (summary of comments by Lewis H. Goldfarb and Sheila L. Birnbaum). While the Advisory Committee rejected the automatic stay suggestion, it did eliminate the "restraint" reference in its final Note. See FED. R. CIV. P. 23(f) advisory committee's note ("Permission to appeal may be granted or denied on the basis of any consideration that the court of appeals finds persuasive.”).

34. See Solimine \& Hines, supra note 4, at 1565 (“[O]pponents of the proposed rule argued that defendants would abuse it and plaintiffs would rarely use it.”).

35. FED. R. CIV. P. 23(f) app. B (summary of comments by Richard A. Koffman); see also Mullenix, supra note 30, at 104 ("Almost all of the critical commentary regarding proposed Rule 23(f) emanated from the plaintiffs' bar.”).

36. FED. R. CIV. P. 23(f) app. B (summary of comments by Stephen Gardner); see also Report of the Advisory Committee on Civil Rules, supra note 31, at 4 ("The main ground of opposition is that applications for permission to appeal will become a routine strategy for increasing cost and delay.”). In a 2001 report, the Advisory Committee appears to describe Rule 23(f) in retrospect as a response more to the lack of interlocutory appellate opportunities for defendants than to wrongly denied plaintiffs:

Advocates for reform advised the Committee that in many cases the certification decision was dispositive of the litigation; once a class is certified and the stakes of the litigation are magnified, whatever the merits of the claim, the defendant may conclude there is little choice but to bow to the overwhelming pressure to settle. To address this problem and to foster the growth of appellate law, the Committee proposed Rule 23(f) . . . .

Memorandum from David F. Levi, Chair, Advisory Committee on the Federal Rules of Civil Procedure to the Hon. Anthony J. Scirica, Chair, Standing Committee on Rules of Practice and Procedure, at 25 (July 31, 2001) available at http://www.uscourts.gov/rules/comment2002/801CV.pdf.

37. See Report of the Advisory Committee on Civil Rules, supra note 31, at 4.

38. See Paul D. Carrington, The New Order in Judicial Rulemaking, 75 JuDICATURE 161, 16465 (1991) (describing the "extended periods of deliberation" of the judicial rulemaking process). Indeed, even as Rule 23(f) was approaching final implementation in 1998, some members of Congress-apparently impatient with the lengthy rulemaking process-introduced statutory versions of Rule 23(f). See Judicial Improvement Act of 1998, S. 2163, 105th Cong. (1998); Richard L. 
Rule 23(f) finally became effective on December 1, 1998. The rule now seems to enjoy a happy (if dull) reputation as a paragon of sound rulemaking, plugging a sorely-needed gap in appellate oversight and fostering the development of a body of appellate jurisprudence on important class action issues. ${ }^{39}$

Recent empirical studies of the implementation of Rule 23(f), however, suggest that plaintiff objectors (and defendant supporters) may have assessed rather accurately the disparate impact the seemingly neutral appellate authority might have. ${ }^{40}$ While the likelihood of plaintiff utilization of the appellate opportunity may have been understated, ${ }^{41}$ studies of the actual workings of Rule 23(f) provide support for the proposition that defendants would seek interlocutory appeal of certification orders more frequently than plaintiffs. The preliminary data also suggests defendants are more likely than plaintiffs to succeed in those appeals. ${ }^{42}$

In an invaluable empirical analysis of docketed Rule 23(f) petitions in the federal circuit courts of appeals, Barry Sullivan and Amy Kobelski Trueblood documented what they described as a "staggering volume of

Marcus, Reform Through Rulemaking?, 80 WASH. U. L.Q. 901, 928-29 (2002) (bemoaning this proposed legislation and the "increased willingness of Congress to take action on matters that are, or might appropriately be, the subject of rulemaking”).

39. Mullenix, supra note 30, at 100, 110 ("Rule 23(f) has been a relatively successful rule," although "something of a yawn.”); Waters, supra note 16, at 587 ("Rule 23(f) proved surprisingly uncontroversial from the beginning, generally receiving the approval of scholars and practitioners alike.”). Indeed, a class action plaintiffs' advocate approvingly described Rule 23(f) as one of the "nonpartisan, functional additions and refinements to Rule 23." Elizabeth J. Cabraser, The Class Action Counterreformation, 57 STAN. L. REV. 1475, 1476 (2005); see also Richard A. Nagareda, Class Certification in the Age of Aggregate Proof, 84 N.Y.U. L. REV. 97, 170-71 (2009) (contrasting CAFA's defendant-favoring removal provisions with Rule 23(f), which "remains available in an evenhanded fashion to whichever side is dissatisfied with the district court's class certification ruling”).

40. See Barry Sullivan \& Amy Kobelski Trueblood, Rule 23(f): A Note on Law and Discretion in the Courts of Appeals, 246 F.R.D. 277, 283-88 (2008); Richard D. Freer, Interlocutory Review of Class Action Certification Decisions: A Preliminary Empirical Study of Federal and State Experience, 35 W. ST. U. L. REV. 13, 18-22 (2007) (analysis based solely on published Rule 23(f) decisions).

41. See supra note 16 and accompanying text (prediction that plaintiffs would never or "rarely" seek appeal).

42. See Sullivan \& Trueblood, supra note 40; cf. Kevin M. Clermont \& Theodore Eisenberg, Plaintiphobia in the Appellate Courts: Civil Rights Really Do Differ From Negotiable Instruments, 2002 U. ILL. L. REV. 947. Professors Clermont and Eisenberg conducted an empirical study of the differences between defendant and plaintiff success rates on appeal, and found that "a defendants' advantage exists, accompanying the general tendency of appellate courts to affirm.” Id. at 971 . The authors explain that the defendant advantage on appeal is likely due to "appellate judges' misperceptions ... of the trial courts' being pro-plaintiff," and conclude that "[i]n the end, the appellate playing field still appears unlevel.” Id. at 949. 
filed Rule 23(f) petitions” in the first eight years of the rule's existence. ${ }^{43}$ Of the 558 petitions filed during that time, 198 were filed by plaintiffs while 278 were filed by defendants. ${ }^{44}$ The rates of petitions and grants varied from circuit to circuit, but "[i]n most circuits, our data suggest that defendants' petitions are granted more often." ${ }^{45}$ Moreover, this study found that of the 126 Rule 23(f) appeals that were actually decided by the courts of appeals during this time frame, defendants won reversal of class certification orders in 67 of 95 cases. $^{46}$

This study, then, suggests a strong incentive for defendants opposed to class certification to pursue interlocutory appeals, at least in the federal courts. Whether this federal appellate trend favoring class action defendants holds true among state appellate courts remains to be seen. ${ }^{47}$ Certainly the strategic advantages of class certification interlocutory appeals have not been lost on defendants, nor on corporate lobbying organizations that consistently include it on their class action reform

43. See Sullivan \& Trueblood, supra note 40, at 283.

44. Id. at 290 tbl. 1.

45. Id. at 286. Overall, the appellate courts granted plaintiff petitions only $22 \%$ of the time, compared to defendant petitions, which were granted $45 \%$ of the time. Id. at 290 tbl. 1. In a 2005 panel discussion at a workshop co-sponsored by the Federal Trade Commission and The Georgetown Journal of Legal Ethics, Judge Diane Wood of the U.S. Court of Appeals for the Seventh Circuit identified both the death knell and the pressure to settle as potential grounds for finding that the certification decision "really is, in effect, the whole case" and thus deserving of appellate scrutiny pursuant to Rule 23(f). See Protecting Consumer Interests in Class Actions, Panel 2: Tools for Ensuring that Settlements Are "Fair, Reasonable and Adequate", 18 GEO. J. LEGAL Eтнісs 1197, 1213 (2005). But Judge Wood also acknowledged that "if somebody has erroneously denied class certification there is only one person whose rights are going to be affected by that.... There's self-correction built into the system because someone else is probably out there with the same class action" and that person would not be precluded by the decision rejecting class certification by a prior would-be class representative's rejection. Id. at 1212.

46. Sullivan \& Trueblood, supra note 40, at $291 \mathrm{tbl}$. 3. The study also found that defendants succeeded in twenty-two of thirty-one appeals by plaintiffs challenging the denial of class certification. Id.

47. See Freer, supra note 40, at 27 (examining published interlocutory appeals in both state and federal courts and concluding that the "single most likely outcome of interlocutory review in the federal and state cases is a reversal of certification"); see also ADMIN. OfFICE OF THE COURTS; OFFICE of COURT RESEARCH, Class CERTIFICATION IN CALIFORNIA: SECOND INTERIM REPORT FROM the STUdy OF CALIFORNIA CLASS ACTION LiTigation 13 (2010) (noting that only one case in the study database included interlocutory review of certified class, but that case did result in a writ of mandamus setting aside class certification); cf. Stephen B. Burbank, The Class Action Fairness Act of 2005 in Historical Context: A Preliminary View, 156 U. PA. L. REV. 1439, 1500 (2008) (noting that in contrast to the Federal Judicial Center's detailed empirical studies of federal class actions, he is "aware of no reliable data, historical or current, concerning state court class actions, and I doubt that reliable data exists for most states"); Emery G. Lee III \& Thomas E. Willging, The Impact of the Class Action Fairness Act on the Federal Courts: An Empirical Analysis of Filings and Removals, 156 U. PA. L. REv. 1723, 1763 (2008) (observing that the "lack of state court data on class actions stems from multiple sources, including the lack of necessary resources to collect the data in the state systems and the lack of common computerized case management systems"). 
wish lists. ${ }^{48}$ And the perception (at least) of a partisan effect of this seemingly nonpartisan appellate rule may go a long way toward explaining the expansion of interlocutory appellate opportunities in state court systems in the wake of Rule 23(f). ${ }^{49}$ Before turning to that state experience and possible explanatory hypotheses, however, one other critical aspect of recent federal class action law must be addressed, the Class Action Fairness Act of 2005.

\section{B. The Class Action Fairness Act}

The Class Action Fairness Act (CAFA), like Rule 23(f), emerged after several years of repeated consideration and deliberation ${ }^{50}$ beginning with a related bill introduced in $1998 .^{51}$ Persistent congressional interest in class action reform can be evidenced not only in CAFA's multiple predecessor bills, but in Congress's successful 1995 effort to reform securities class action practices. ${ }^{52}$

CAFA altered the federal diversity jurisdiction statute to enable federal courts to hear most class actions involving minimally diverse parties in actions involving over 100 plaintiffs and over $\$ 5$ million. ${ }^{53}$

48. See e.g., U.S. Chamber InStitute FOR Legal Reform, 101 Ways to Improve State Legal SYSTEMS: A USER's GUIDE TO PROMOTING FAIR AND EFFECTIVE CIVIL JUSTICE, 20 (2009) available at http:w.instituteforlegalreform.com/images/stories/documents/pdf/research/101waysto improvestatelegalsystems.pdf (listing first among five proposed class action reforms: "Provide for interlocutory appeal of the grant or denial of class certification.”). Similarly, the American Legislative Exchange Council, a non-profit organization of state legislators promoting conservative policy approaches, promulgated model legislation listing the provision of discretionary appellate review of class certification orders as one of "five changes that states could adopt in an effort to achieve modest (but significant) improvements to their statutes and/or court rules governing class actions.” AMERICAN Legislative EXCHANGE COUNCIL, Class ACTION IMPROVEMENTS ACt (2000).

49. See infra Figure 1.

50. See Edward F. Sherman, Class Actions After the Class Action Fairness Act of 2005, 80 TUL. L. REV. 1593, 1593-97 (2006) (describing CAFA's legislative history); see also Burbank, supra note 47, at 1441 (noting that CAFA "resulted from years of intense lobbying (on both sides of the aisle by interest groups associated with both plaintiffs and defendants), partisan wrangling, and, following two successful filibusters, fragile compromises").

51. See Class Action Jurisdiction Act of 1998, H.R. 3789, 105th Cong. (1998); Class Action Fairness Act of 1998, S. 2083, 105th Cong. (1998).

52. See Private Securities Litigation Reform Act of 1995, Pub. L. No. 104-67, 109 Stat. 737 (codified in scattered sections of 15 U.S.C.). See generally Michael A. Perino, Fraud and Federalism: Preempting Private State Securities Fraud Causes of Action, 50 STAN. L. REV. 273, 288-98 (1998) (describing legislative history of securities class action reform statute); Joel Seligman, The Private Securities Reform Act of 1995, 38 ARIZ. L. REV. 717 (1996).

53. Class Action Fairness Act of 2005, Pub. L. No. 109-2, § 4(d)(5)-(6), 119 Stat. 4 (2005) (codified in scattered sections of 28 U.S.C.). See generally Sherman, supra note 50. Professor Sherman described CAFA as "the most significant change in class action practice since the federal class action rule (Rule 23) was amended in 1966.” Id. at 1593. 
The Act's preamble points to Congress's view that state court class action abuses necessitated the federalization of a broad swath of class actions in state courts. ${ }^{54}$ While those assertions have been roundly criticized as largely anecdotal or misleading, ${ }^{55}$ and CAFA itself has been the subject of much withering academic criticism, ${ }^{56}$ Congress's stated motivations reveal a popular perception of state courts as rogue and unreliable guardians against the most insidious class action practices.

Yet by its own terms, CAFA does not apply to all state court class actions, and while state class actions post-CAFA have undoubtedly declined, ${ }^{57}$ they are far from extinct. ${ }^{58}$ Plaintiffs' attorneys resolved to

\section{The preamble reads:}

Abuses in class actions undermine the national judicial system, the free flow of interstate commerce, and the concept of diversity jurisdiction as intended by the framers of the United States Constitution, in that State and local courts are -

(A) keeping cases of national importance out of Federal court;

(B) sometimes acting in ways that demonstrate bias against out-of-State defendants; and

(C) making judgments that impose their view of the law on other States and bind the rights of the residents of those States.

Pub. L. No. 109-2, § 2(a)(4), 119 Stat. 4, 5.

55. See, e.g., Cabraser, supra note 39, at 1516-17 (CAFA “ “is based more on misperception than truth"” regarding allegedly "plaintiff-friendly” state courts "rife with class action abuses.”) (quoting Marcia Coyle, A Reform's Fate Rests in Federal Courts; Delays, Larger Classes to Come in Class Action Reform, NAT'L L.J., Feb. 14, 2005, at 1, 1)). Indeed, the National Conference of State Legislatures, the Conference of Chief Justices of the State Courts, and a coalition of fourteen state attorneys general all submitted letters in opposition to CAFA protesting the lack of empirical support for such findings. See Letter from Sen. Michael Balboni, Chair, Nat'l Conference of State Legislatures Law and Criminal Justice Comm., to U.S. Senate 1 (Feb. 2, 2005), http://www.citizen .org/documents/NCSLClassActionLetter2-05.pdf (urging that there is no evidence that "states have broadly overreached or are unable to address the problems themselves”); Letter from Annice M. Wagner, President, Conference of Chief Justices, to Hon. Patrick J. Leahy, Chairman, Senate Comm. on the Judiciary (Mar. 28, 2002), http://www.citizen.org/documents/CCJLetter.pdf (pointing out the absence of "hard evidence of the inability of the state judicial systems to hear and decide fairly class actions brought in state courts”); Letter from Eliot Spitzer, Attorney General of the State of New York et al., to Hon. Bill Frist, Majority Leader, U.S. Senate, and Hon. Harry Reid, Minority Leader, U.S. Senate (Feb. 7, 2005), in 151 CoNG. REC. H644-45 (daily ed. Feb. 16, 2005) ("There is no compelling need or empirical support for such a sweeping change in our long-established system for adjudicating state law issues.”).

56. See, e.g., Edward A. Purcell, Jr., The Class Action Fairness Act in Perspective: The Old and the New in Federal Jurisdictional Reform, 156 U. PA. L. REV. 1823, 1887 (2008) ("CAFA did not so much save defendants from biased state courts as reward them with access to an alternate forum that they regarded as more favorable to their interests.”); Burbank, supra note 47, at 1542 ("At the end of the day, CAFA's exceedingly narrow exceptions are revealed as another depressing example of legislative overreaching by those who invoke the virtues of federalism when it is convenient to do so.”).

57. See, e.g., Steven S. Gensler, The Other Side of the CAFA Effect: An Empirical Analysis of Class Action Activity in the Oklahoma State Courts, 58 KAN. L. REV. 809, 825-27 (2010) (finding “a significant reduction in class action filings in the Oklahoma state courts post-CAFA”).

58. See, e.g., Richard L. Marcus, Assessing CAFA’s Stated Jurisdictional Policy, 156 U. PA. L. REV. 1765, 1789 n.117 (2008) (pointing out that the number of class actions filed in California state courts in 2005 may have been down from pre-CAFA highs, but was "still higher than in 2003, which 
remain in state court, ${ }^{59}$ for example, may seek to avoid CAFA removal by limiting the total amount of class damages to less than CAFA's $\$ 5$ million threshold. ${ }^{60}$ They may also consolidate plaintiffs in plausible units of less than 100 persons $^{61}$ or sue a home-state defendant on behalf of a class of largely in-state plaintiffs. ${ }^{62}$ The threat of the latter option likely leads most Fortune 500 corporations to be acutely cognizant of state court class action rules (and appellate practices) in their home states. ${ }^{63}$ And CAFA merely permits, it does not require, the removal of class actions filed in state courts, which could provide an attractive state court forum for seeking approval of a settlement class that might not pass

was higher than 2002”); Gregory C. Cook, The Alabama Class Action: Does it Exist Any Longer? And Does it Matter?, 66 ALA. LAW. 289, 294 (2005) (asserting that post-CAFA, the "Alabama class action is not dead-but it has been properly limited to those cases affecting Alabama and limited to those claims and cases that Alabama circuit courts have the time and resources to manage").

59. See Roger K. Smith, Keeping Your State Court Class Action in State Court, LITIG. News, http://www.abanet.org/litigation/litigationnews/practice_areas/classaction-state-court-CAFA.html (last visited Apr. 16, 2010) (advising post-CAFA plaintiffs that "if you are careful in your definition of the proposed class, careful in the amount you request on behalf of your clients, and careful in how you plan to try your clients' claims, then you can keep your state court class action in state court”).

60. See Emery G. Lee III \& Thomas E. Willging, The Impact of the Class Action Fairness Act on the Federal Courts: An Empirical Analysis of Filings and Removals, 156 U. PA. L. REV. 1723, 1734-35 (2008) (in light of a "2003 FJC survey of attorneys in recently terminated class actions ... finding that the median recovery in class action settlements was $\$ 800,000$ and that $75 \%$ of the settlements were valued at less than \$5.2 million," and "the \$5 million CAFA limit might exclude a substantial majority of class actions, depending on the relationship between the amount in controversy and the final settlement amount") (citing Thomas E. Willging \& Shannon R. Wheatman, Attorney Choice of Forum in Class Action Litigation: What Difference Does It Make?, 81 NotRE DAme L. Rev. 591, 650 (2006)); W. Pitts Carr, Class Litigation, Fulton COUNTY DAILY ReP., Feb. 16, 2006 (Ga.) ("Smaller cases may still find repose in state court [post-CAFA], but you are going to have to plead smart to make it stick.").

61. See generally Tanoh v. Dow Chemical Co., 561 F.3d 945 (9th Cir. 2009) (affirming federal district court remand of seven groups of less than 100 plaintiffs, finding CAFA's mass action removal provisions inapplicable). But see Lee \& Willging, supra note 54, at 1735 (noting that the 2003 FJC class action survey "found that the median size of class actions removed to federal courts and retained in the face of a motion to remand was 1000 members," suggesting "that the 100-class member restriction will have limited effect" on CAFA's jurisdictional reach).

62. See 28 U.S.C. § 1332(d)(4)(B) (2006) (federal court shall decline jurisdiction where "twothirds or more of the members of all proposed plaintiff classes in the aggregate, and the primary defendants, are citizens of the State in which the action was originally filed"); Georgene Vairo, Foreword: Complex Litigation in California and Beyond, 41 LoY. L.A. L. REV. 763, 769-70 (2008) ("If plaintiffs believe that it is more likely that a class will be certified under California's rules, they ought to consider proposing a class that consists mainly of California citizens. With such a proposed class, if a [California-based defendant] removes the case under CAFA, it will be returned to California state court under CAFA's mandatory remand provision ....”). But see Sherman, supra note 50, at 1597 (suggesting that in light of the limits of CAFA's jurisdictional exceptions, "it seems unlikely that many class actions can be crafted by class action attorneys to stay in state courts").

63. See infra Part III; see also Gregory C. Cook \& Jennifer H. Clark, Strategy Decisions On CAFA: The Defense Perspective, 19 PRAC. LiTIG. 17, 18 (2008) (noting that "state appellate courts can sometimes be more favorable" for defendants, specifically those states with "statutes providing appeals of class certification as a matter of right—something not available in federal court”). 
muster under "the exacting federal court settlement-approval standards. ${ }^{64}$

In a previous version of CAFA, members of Congress sought to change Rule 23(f) itself. Section 6 of the House version of the "Class Action Fairness Act of 2003” proposed to amend 28 U.S.C. § 1292(a) to include an immediate right of appeal for class action litigants challenging class certification orders, as well as an automatic stay of lower court proceedings during the pendency of the appeal. ${ }^{65}$ This statutory attempt to alter Rule 23(f)'s balance of discretionary appellate review coupled with a default rule allowing proceedings to continue during the pendency of any appeal was the subject of a stern letter written by Judge Anthony J. Scirica, the Chair of the Judicial Conference Committee on Rules of Practice and Procedure, to the Chair of the House Judiciary Committee. ${ }^{66}$

Urging the immediate withdrawal of the class action appeal provisions of the bill, Judge Scirica contended that they would "directly conflict[] with Rule 23(f)" in a manner "inconsistent with the Rules Enabling Act rulemaking process.”67 Judge Scirica pointedly explained that Rule 23(f) had been "promulgated as a result of an exhaustive study of class action practices," and was believed to be "working well" as presently constructed. ${ }^{68}$ Providing a right to interlocutory appeal, on the other hand, "might tempt a party to file an interlocutory appeal solely for tactical reasons," while an automatic stay "could disrupt the district court's ability to manage the case." ${ }^{\circ 9}$ Judge Scirica was apparently persuasive, as subsequent versions of CAFA, including the one enacted in 2005 , did not include the proposed class action appellate provisions. ${ }^{70}$

64. Marcus, supra note 58, at 1799; see also Cook \& Clark, supra note 63, at 17-18 (urging defendants seeking quick settlements of class actions to stay in state courts that "tend to be somewhat less strict in their evaluation of settlement agreements, a plus for defendants”).

65. See Class Action Fairness Act of 2003, H.R. 1115, 108th Cong. § 6 (2003).

66. Letter from Judge Anthony J. Scirica, Chair, Committee on Rules of Practice and Procedure of the Judicial Conference of the United States, to Honorable F. James Sensenbrenner, Jr., Chair, Committee on the Judiciary, United State House of Representatives (May 12, 2003) (on file with author).

67. Id. at 1.

68. Id. at 2 .

69. Id.

70. See, e.g., Class Action Fairness Act of 2004, S. 12, 108th Cong. (2004). 


\section{THE STATE EXPERIENCE: CHANGES IN CLASS ACTION} INTERLOCUTORY APPELLATE RULES POST-FRCP 23(F)

\section{A. Overview}

In the decade after Rule 23(f), as can be seen in Figure 1, a sizeable number of states altered existing appellate rules relating to interlocutory review of class certification orders. I refer to all such states in this article as "amending" states, although the form of the amendment varies among the states: from judicial rulemaking to legislative rulemaking; from amendments directly to the state's class action rule to amendments to its rules of appellate procedure; from amendments authorizing discretionary appeals to amendments authorizing appeals as of right.

Even before Rule 23(f), a number of states allowed, by rule or statute, interlocutory appeals of class certification orders as of right ${ }^{71}$ or by discretion of the state appellate courts. ${ }^{72}$ Another set of states

71. See ARK. R. App. P. 2(a)(9); IowA R. Civ. P. 1.264(3); FlA. R. ApP. P. 9.130(a)(3)(C)(vi), 9.130(a)(6); N.D. R. Civ. P. 23(d)(3); OKLA. STAT. ANN. tit. 12 § 993(A)(6) (Supp. 2010); TEX. CIV. PRAC. \& REM. CODE ANN. § 51.014(a)(3) (Vernon 2008). States allowing appeals as of right for both grants and denials of class certification predominantly do so through rules or statutes specifically limited to class actions. See sources cited supra. But see N.Y. C.P.L.R. 5701 (McKinney Supp. 2010); Adam Feit, Tort Reform, One State at a Time: Recent Developments in Class Actions and Complex Litigation in New York, Illinois, Texas, and Florida, 41 LoY. L.A. L. REV. 899, 908 (2008) ("Unlike the federal system and most other states, New York gives parties the right to appeal almost any civil interlocutory order.”).

72. See, e.g., DeL. R. S. CT. 42; MASS. GEN. LAWS ANN. ch. 231, § 118 (West 2000); Mich. CT. R. 7.302; MinN. R. CIV. APP. P. 105.01; N.J. COURT RULE 2:2-4. 


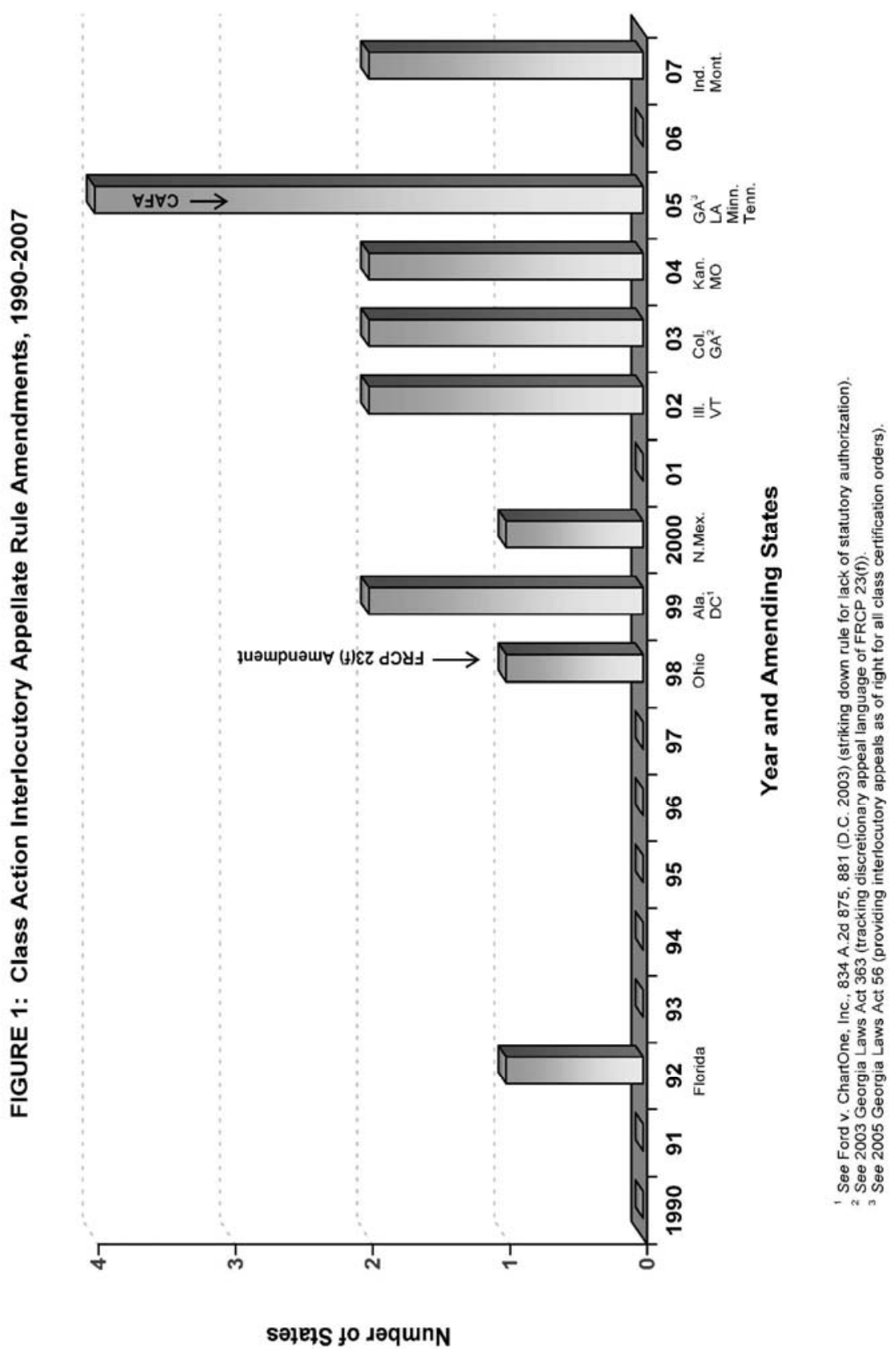


restricted appeals as of right only to plaintiffs denied the right to proceed on a class basis, ${ }^{73}$ rejecting (explicitly or implicitly) the Supreme Court's views in Cooper on the finality of such orders. ${ }^{74}$ The majority of states, however, limited interlocutory appeals of class certification orders, particularly orders granting class certification, in much the same manner as the federal courts did prior to the promulgation of Rule 23(f). They imposed stringent appellate criteria, required trial court approval, ${ }^{75}$ or permitted such orders only to be reviewed by grant of extraordinary writ. $^{76}$

73. See, e.g., State ex rel. Anaconda Aluminum Co., 490 P.2d 351, 351-52 (Mont. 1971) ("It should be noted that [former MONT. R. APP. R. 1(b)(2)] provides for an appeal from an order refusing to permit an action to be maintained as a class action.”); Butler v. Audio/Video Affiliates, Inc., 611 So. 2d 330 (Ala. 1992); Daar v. Yellow Cab Co., 433 P.2d 732 (Cal. 1967); Johnson v. Travelers Ins. Co., 515 P.2d 68 (Nev. 1973); Alessandro v. State Farm Mut. Auto. Ins. Co., 409 A.2d 347 (Pa. 1979). While one of the states in this category also allowed discretionary appeals by defendants, see PA. R. APP. P. 312, the other eight states required defendants faced with a certified class to seek extraordinary review by writ. See, e.g., Ex parte AmSouth Bancorp., 717 So. 2d 357, 361 (Ala. 1998); Meyer v. Eighth Judicial Dist. Court, 885 P.2d 622 (Nev. 1994); Blue Chip Stamps v. Superior Court, 556 P.2d 755 (Cal. 1976). One is hard-pressed to find much evidence of successful writ petitions in most of these states, but the appellate courts of Alabama and California seem to have been somewhat more liberal in their approach. See Glenn A. Danas, The Interstate Class Action Jurisdiction Act of 1999: Another Congressional Attempt to Federalize State Law, 49 EMORY L. J. 1305, 1325 n.122 (2000) (Alabama "traditionally allowed for frequent class certification review via writs of mandamus”); Freer, supra note 40, at 26 (noting that in California state courts, "the writ of mandate is used more generally than in federal practice").

74. Coopers \& Lybrand v. Livesay, 437 U.S. 463 (1978); see also supra note 13 and accompanying text.

75. See, e.g., OR. Rev. STAT. § 19.225 (2003); Levine v. Empire Sav. \& Loan Ass'n, 557 P.2d 386, 387 (Colo. 1976); Aetna Cas. \& Sur. Co. v. Cantrell, 399 S.E.2d 237, 238 (Ga. Ct. App. 1990); Petruchius v. Don Roth Rests., Inc., 398 N.E.2d 1228, 1230 (Ill. 1979).

76. See, e.g., Philip Morris Inc. v. Angeletti, 752 A.2d 200, 216-18 (Md. 2000) (granting writ of mandamus but emphasizing that "[i]t will be the rare case indeed which justifies the issuance of interlocutory mandamus relief”); State ex rel. Byrd v. Chadwick, 956 S.W.2d 369, 376 (Mo. Ct. App. 1997); Millett v. Atl. Richfield Co., 760 A.2d 250 (Me. 2000); Lake v. Piper, Jaffray \& Hopwood, Inc., 324 N.W.2d 660, 662 (Neb. 1982); Knowles v. Standard Sav. \& Loan Ass'n, 261 S.E.2d 49 (S.C. 1979). But see Garrard County Bd. of Educ. v. Jackson, 12 S.W.3d 686, 689 (Ky. 2000) (holding that a class certification orders are not even "a proper subject for relief in the form of a writ of mandamus"). 
Table 1: Pre-Rule 23(f) Availability of Interlocutory Appeal of Class Certification Orders

\begin{tabular}{|c|c|c|c|c|c|}
\hline $\begin{array}{c}\text { Number of } \\
\text { States }\end{array}$ & $\begin{array}{c}\text { As of } \\
\text { Right }\end{array}$ & $\begin{array}{c}\text { Denial: As of } \\
\text { Right/Grant: } \\
\text { Discretionary }\end{array}$ & $\begin{array}{c}\text { Denial: As of } \\
\text { Discre- } \\
\text { tionary }\end{array}$ & $\begin{array}{c}\text { Limited, } \\
\text { Right/Grant: } \\
\text { Extraordinary }\end{array}$ & $\begin{array}{c}\text { Rare, or } \\
\text { Unavailable }\end{array}$ \\
\hline $\begin{array}{c}\text { Total States } \\
\text { as of } \\
\text { July 1, 1998 }\end{array}$ & 8 & 1 & 8 & 8 & 24 \\
\hline \hline $\begin{array}{c}\text { Amending } \\
\text { States }\end{array}$ & 1 & 0 & 1 & 3 & 10 \\
$(12.5 \%)$ & $(0 \%)$ & $(12.5 \%)$ & $(37.5 \%)$ & $(42 \%)$ \\
\hline $\begin{array}{c}\text { Non- } \\
\text { Amending } \\
\text { States }\end{array}$ & 7 & 1 & 7 & 5 & $(62.5 \%)$ \\
$(87.5 \%)$ & $(100 \%)$ & $(87.5 \%)$ & $(58 \%)$ \\
\hline
\end{tabular}

As Table 1 demonstrates, the lion's share of changes in the wake of Rule 23(f) occurred among those states that previously had imposed limits on immediate appeals of class certification orders, as might have been expected. Of the forty-nine jurisdictions authorizing class actions, ${ }^{77}$ twenty-three states and the District of Columbia limited or rarely permitted interlocutory appeals of class certification orders prior to 1998. ${ }^{78}$ Another eight states allowed plaintiffs to appeal the denial of class certification but required defendants challenging a certified class to seek extraordinary appellate review. ${ }^{79}$ Thirteen out of these thirty-two states, or forty percent, expanded opportunities for immediate appellate review, either by providing permission to seek discretionary review of class certification decisions directly from appellate courts, paralleling Federal Rule 23(f), or by allowing appellate review as of right for all class litigants. ${ }^{80}$ Conversely, only two of the seventeen states (or twelve

77. Neither Mississippi nor Virginia authorizes general class actions. See Thomas D. Rowe, Jr., State and Foreign Class Actions Rules and Statutes: Differences From-and Lessons for?Federal Rule 23, 35 W. ST. U. L. REV. 147, 148-49 (2007) (describing Mississippi's "liberal use of non-class permissive-party joinder" and Virginia's limited treatment of class actions and multiclaimant litigation).

78. See supra Table 1.

79. See id.; see also supra note 73 and accompanying text.

80. See supra Table 1. 
percent) that previously had allowed for class action appeals as of right or by discretion amended their class action appellate rules after $1998 .{ }^{81}$

It is notable, however, that all of the changes resulted either in an expansion or a codification of existing appellate rights rather than a restriction of appellate rights. In other words, none of the states that previously permitted interlocutory appeals as of right tracked the federal rule by limiting such appeals to the discretion of the appellate courts. Following the Supreme Court's decision in Coopers, however, two states did exactly that, interpreting their final judgment rules post-Coopers to no longer allow appeals as of right from certification orders. ${ }^{82}$

Figures 2 and 3 together paint a fairly striking illustration of the impact of these state class action appellate rule changes. ${ }^{83}$ Figure 2 presents the thirty-five percent of states prior to Rule 23(f) that provided expanded appellate access for class litigants, and the sixty-five percent of states that limited such appeals. Figure 3 shows the same status today, with the numbers virtually flipped: adding the amending states to the states with preexisting appellate rights, fully sixty-one percent of states now provide expanded appellate opportunities for class litigants while only thirty-nine percent do not.

81. See id. Minnesota and Louisiana fall into this category, codifying what appears to have been their preexisting appellate practices. Minnesota's appellate courts already provided an opportunity for class litigants to seek direct discretionary review. See infra notes 142-43 and accompanying text. In Louisiana, the amending statute purported to codify prior judicial interpretations of the applicability of a generic appeals statute. See infra notes 144-46 and accompanying text.

82. See Smith v. Tobin, 311 N.W.2d 209, 211 (S.D. 1981) (overruling Rollinger v. J. C. Penney Co., 192 N.W.2d 699 (S.D. 1971)); Hanania v. City of Tucson, 597 P.2d 190, 191-92 (Ariz. Ct. App. 1979) (overruling Home Federal Sav. \& Loan Ass'n v. Pleasants, 534 P.2d 275 (Ariz. Ct. App. 1975)). Several other states simply followed the Supreme Court's restrictive reasoning in Coopers. See, e.g., Petruchius v. Don Roth Rest., Inc., 398 N.E.2d 1228, 1232 (Ill. App. Ct. 1979); Snowden v. Baltimore Gas \& Elec. Co., 479 A.2d 1329, 1332-35 (Md. 1984); Ralph v. American Family Mut. Ins. Co., 809 S.W.2d 173, 174 (Mo. Ct. App. 1991); Bayberry Assoc. v. Jones, 783 S.W.2d 553, 557-58 (Tenn. 1990).

83. These state-by-state snapshots reflect the availability of class appeals as of July 1, 1998 (Figure 2) and July 1, 2009 (Figure 3). 
Figure 2: Availability of Interlocutory Appeals from Class Certification Orders, 1998 O-Interlocutory Appeals

- Limited Interlocutory Appeals

O- No Class Actions

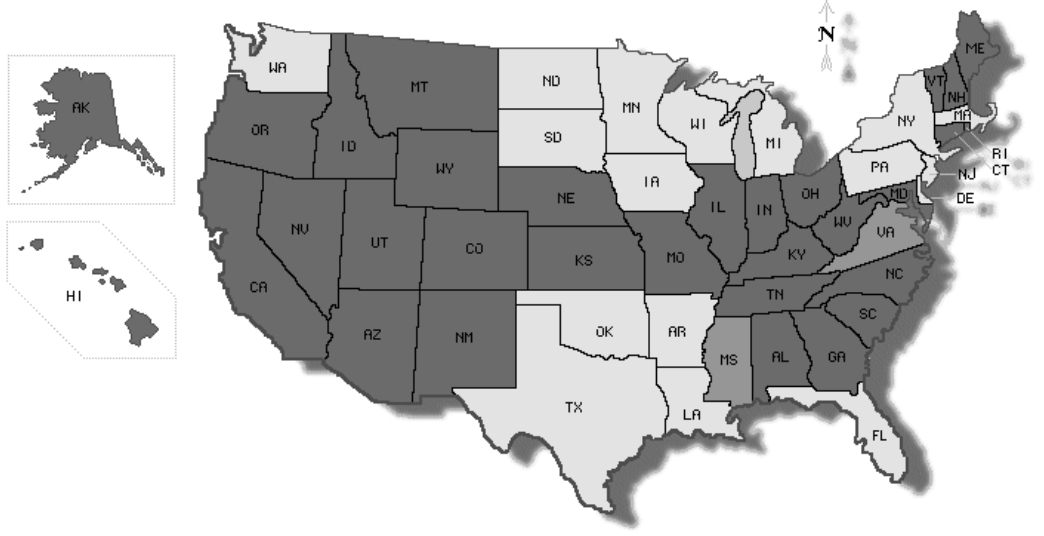

Figure 3: Availability of Interlocutory Appeals from Class Certification Orders, 2009

O-Interlocutory Appeals

- Limited Interlocutory Appeals

O- No Class Actions

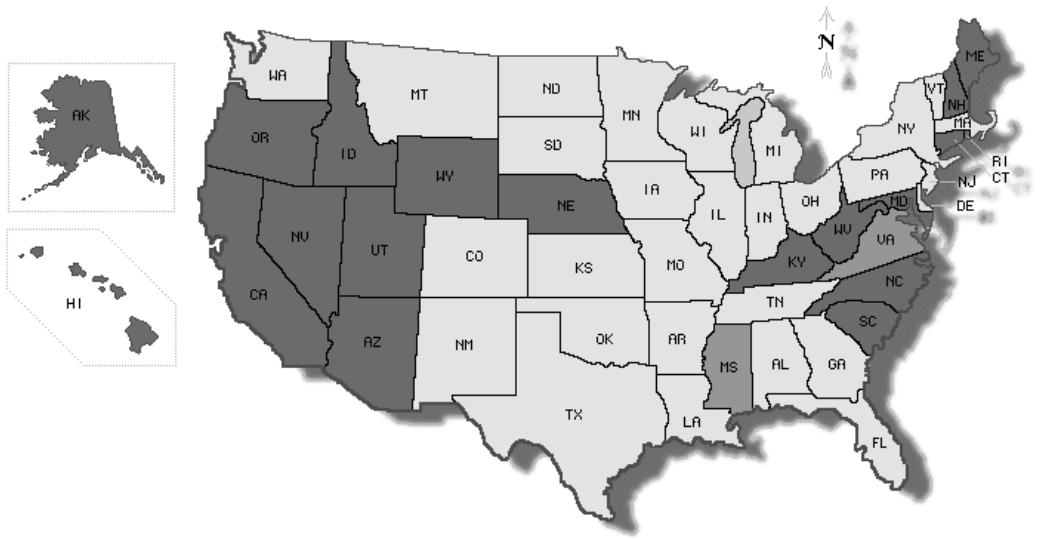




\section{B. State-by-State Chronology}

Ohio, the first amending state in this era, ${ }^{84}$ had a rather complicated class action appeals story. ${ }^{85}$ Well before Coopers, Ohio recognized the "death knell" exception for denials of class certification pursuant to its "final order" statute. ${ }^{86}$ In 1981, and again in 1990, the Ohio Supreme Court further interpreted that statute to include orders granting class certification. $^{87}$ In 1993, however, Ohio's high court overruled this second line of cases $^{88}$ and, in 1998, reaffirmed that orders approving class certification were interlocutory and not appealable as of right under the final order statute. ${ }^{89}$

In 1998, the Ohio General Assembly amended that statute to add two new distinct categories of appealable final orders, making clear that the statute should indeed apply to orders determining whether "an action may or may not be maintained as a class action." 90 As originally introduced in 1997, the bill sought only to add provisional remedies to the statute, but in the spring of 1998, the Senate Judiciary Committee added the provision extending "final order" status to class certification

84. Ohio is included even though its General Assembly actually amended the relevant interlocutory appeals statute to include class action decisions effective July 22, 1998, just over four months before FRCP 23(f) went into effect. Ohio's amendment occurred well after the Judicial Conference of the United States approved Rule 23(f) in 1997, and the United States Supreme Court gave the rule its final approval in early 1998. See generally Report of the Proceedings of the Judicial Conference of the United States (September 23, 1997), available at http:/www.uscourts.gov /judconf/proceedings/1997-09.pdf; WRIGHT ET AL., supra note 8 (noting the Supreme Court's approval of Rule 23(f) on April 24, 1998).

85. See Gary L. Garrison, Appellate Jurisdiction in Ohio Over Final Appealable Orders, 50 CleV. ST. L. REV. 595, 635-37 (2002).

86. See Roemisch v. Mutual of Omaha Ins. Co. 314 N.E.2d 386, 387-89 (1974); see also OHIO REV. CODE ANN. § 2505.02 (defining "final order" appealable as of right to include "[a]n order that affects a substantial right in an action which in effect determines the action and prevents a judgment”).

87. See Dayton Women’s Health Ctr. v. Enix, 555 N.E.2d 956, 958 (Ohio 1990); Amato v. Gen. Motors Corp., 423 N.E.2d 452, 455 (Ohio 1981).

88. See Polikoff v. Adam, 616 N.E.2d 213, 218 (Ohio 1993).

89. See Chamberlain v. AK Steel Corp., 696 N.E.2d 569, 569 (Ohio 1998). Justice Lundberg Stratton dissented in Chamberlain, noting that the amended final order statute expressly allowing appeals of class certification orders, admittedly not yet in effect at the time the case was submitted to the Court, nevertheless merely "clarifies the public policy that both the granting and denial of class certification are appealable.” Id. at 571 (Lundberg Stratton, J., dissenting) (emphasis in original).

90. See H.R. 394, 122nd Gen. Assem. (Ohio 1998); OHIO REV. CoDE AnN. § 2505.02(B)(5) (West 2009). The amendment also added definitions of statutory terms based largely on the Ohio Supreme Court's prior decisions interpreting those terms. See H.R. 394. 
orders. $^{91}$ The bill as amended passed both houses swiftly and without dissenting votes. ${ }^{92}$

In 1999, Alabama's legislature similarly acted to expand available appellate opportunities specifically to benefit defendants seeking to challenge class certification orders. Like Ohio, Alabama rejected the reasoning of the Supreme Court in Coopers, providing immediate appeals as of right for plaintiffs denied the right to proceed on a class basis. ${ }^{93}$ But the Alabama Supreme Court still required defendants faced with certified classes to seek appellate review by writ of mandamus. ${ }^{94}$

Apparently discontented with Alabama's judicially promulgated class action rule in this and other respects, ${ }^{95}$ the Alabama Legislature enacted a statute to regulate a host of class action practices, ${ }^{96}$ including the addition of an immediate right to appeal class certification orders. ${ }^{97}$

91. The nonprofit Ohio Legislative Budget Office (OLBO) released a report on the revised bill stating that although the

bill would potentially increase the number of cases that may be heard on appeal, ... the

Ohio Judicial Conference and the association of Ohio’s Appellate Court Judges have

indicated that expanding the definition of 'final order' as provided in this bill will affect a minimal number of cases and would not increase caseloads to any appreciable extent.

OLBO, Fiscal Note AND Local Impact Statement, H.B. 394 (1998), available at http:// www.lbo.state.oh.us/122ga/pdf/122/hb0394sp.pdf. The OLBO also stated that "[c]urrently, there may be some cases that are not being appealed because a meaningful or effective remedy is no longer available once a final judgment has been rendered.” Id. This exact language, however, also appeared in the OLBO's previous fiscal impact statement for the original bill. See OLBO, FISCAL NOTE AND LOCAL IMPACT STATEMENT, H.B. 394 (1997), available at http://www.lbo.state.oh /122ga/pdf/122/hb0394in.pdf. As amended, the bill then swiftly passed both the Senate and the House without opposition.

92. See Ohio Legis. Serv. Commission, 122nd Final Bill Analysis, Sub. H.B. 394 (1998).

93. See Butler v. Audio/Video Affiliates, Inc., 611 So. 2d 330, 331 n.1 (Ala. 1992) ("We recognize that this holding is contrary to current practice in the federal courts, but we reject the reasoning of Coopers \& Lybrand v. Livesay....”). Twelve years earlier, the Alabama Supreme Court cited Coopers far more favorably for the proposition that certification orders were interlocutory, and similarly followed federal appellate precedent in holding that Alabama's $\S$ 1292(b) equivalent was inapplicable to review class certification orders. See First Ala. Bank of Montgomery, N.A. v. Martin, 381 So. 2d 32, 34-36 (Ala. 1980).

94. See Ex parte AmSouth Bancorp., 717 So. 2d 357, 361 (Ala. 1998) ("A petition for a writ of mandamus is the proper means for reviewing an order certifying a case as a class action.”).

95. See Jerome A. Hoffman, Respecting the Rules: The Legislature Tinkers with Rule 23, 60 ALA. LAW. 404, 408 (1999) (criticizing the legislature's intrusion into Alabama's ordinarily careful judicial rulemaking process as "carelessly considered," and amounting to unnecessarily "inflexible mandatory complications"). Several years later, the Alabama Supreme Court's advisory committee more sanguinely observed that the "act works few changes in Rule 23 as the Alabama Supreme Court has already interpreted it.” See Committee Comments to Rule 23 (February 13, 2004).

96. Act No. 99-250, 1999 Ala. Laws 329 (codified at AlA. CoDE §§ 6-5-640-642 (1975)). The Act also added a number of class procedures such as a "full evidentiary hearing on class certification," the application of a "rigorous analysis" standard for class certification determinations, and an automatic stay pending appeal. Id. § 6-5-641.

97. ALA. CODE § 6-5-642 (2005). Given the apparent frequency of writs of mandamus issued by the Alabama Supreme Court in the late 1990s to reverse class certification orders, it has been 
As in Ohio, Alabama's class action bill passed with no dissenting votes. ${ }^{98}$ The Birmingham News reported at the time that the class action bill was part of a three-bill package of legislation "aimed at making the state's civil justice system more friendly to businesses." 99 It should be noted that despite this wide-ranging legislative effort to curb state class actions, $^{100}$ Alabama's courts were still cited by numerous CAFA supporters as evidence of the need for federalization of class actions. ${ }^{101}$

The next four jurisdictions, D.C., New Mexico, Vermont, and Illinois, adopted Rule 23(f) (or its appellate rule equivalent) by judicial rulemaking. ${ }^{102}$ The District of Columbia Superior Court's adoption of Rule 23(f) in 1999 was invalidated several years later. ${ }^{103}$ The D.C. Court of Appeals held that absent express statutory authority or a D.C. Code equivalent to $\S 1292(\mathrm{e})$, the D.C. Superior Court simply did not have the power to "promulgate a jurisdiction-enlarging rule such as Rule 23(f)."104

suggested that the appellate aspects of this statute may merely have codified a de facto right already enjoyed by defendants. See Danas, supra note 73, at 1325 n.122. But absent the statutory right of appeal, future justices on Alabama's highest court might not always have been as receptive to defendants' writs.

98. See Bill Poovey, Trial Lawyers Spokesman: Tort Bills Not Consumer Aids, BIRMINGHAM NEws, May 28, 1999, at 5C (noting that governor signed class action reform bill "which received final approval with no dissenting votes").

99. Stan Bailey, Panel Oks Tort Reform Package, BiRmingham News, Apil 29, 1999, at 1A. The other two bills involved caps on punitive damages awards and venue changes for civil damage suits. Id.; see also Jerry Underwood, Class Action Reform: End to Abuses, BIRMINGHAM News, May 23, 1999, at 1D (noting that while the punitive damages bill had received more attention, the class action bill was nevertheless "high on the wish list for business interests"). As the general counsel for one of Alabama's corporations explained, companies want an immediate right to appeal certification orders because "“[t]he clout of a class action is the certification.'” Underwood, supra.

100. See also Linda S. Mullenix, Abandoning the Federal Class Action Ship: Is There Smoother Sailing For Class Actions in Gulf Waters?, 74 Tul. L. REV. 1709, 1763-67 (2000) (describing a concurrent string of Alabama Supreme Court cases conservatively interpreting Alabama's Rule 23); Danas, supra note 73, at 1327-29. According to Alabama’s Mobile Register, “[b]usiness interests effectively took control of the [Alabama Supreme Court] by 1997," and "members of the business community who want to preserve and expand the [1999 legislative tort reforms] plan to focus on electing pro-limits judges to the Alabama Supreme Court.” Jeff Amy, War on Torts Far From Over, MobiLe Register, Aug. 24, 1999, at A1.

101. See Freer, supra note 40, at 25.

102. D.C. R. Civ. P. 23(f) (amended June 22, 1999); N.M. Dist. CT. R. CIV. P. 1-023(F) (amended Dec. 4, 2000); VT. R. CIV. P. 23(f) (amended Mar. 6, 2002); ILL. S. CT. R. 306(a)(8) (amended Dec. 31, 2002).

103. See Ford v. ChartOne, Inc., 834 A.2d 875 (D.C. 2003).

104. Id. at 880; see also Palmer v. Friendly Ice Cream Corp., 940 A.2d 742, 751 (Conn. 2008) (holding that court lacked Rule 23(f) equivalent jurisdiction to consider appeal from denial of class certification in absence of statutory authorization); Salmonsen v. CGD, Inc., 661 S.E.2d 81, 87 (S.C. 2008) (declining to allow appeal of class certification order in the absence of a state rule or statutory equivalent to Rule 23(f) because to do so "would represent a significant departure from [South Carolina's] established appealability jurisprudence”); $c f$. Royal Fin. Serv., Inc. v. Eason, 961 A.2d 1161, 1164 n.2 (Md. Ct. Spec. App. 2008) (noting that in the decade since Rule 23(f), Maryland's "Court of Appeals has shown no inclination to change the existing law" by "amend[ing] Maryland's 
In New Mexico, the proposed rule received criticism during the public comment period from some members of the state plaintiffs' bar echoing many of the objections voiced during consideration of the federal rule: the proposed rule would "weaken the class action procedure... while handing defendants another mechanism to make litigation more costly and time consuming."105 Moreover, the Chief Judge of the New Mexico Court of Appeals weighed in, asking "[i]s there such a problem with district courts refusing to certify genuine questions concerning grant or denial of class certifications that this rule... [is] necessary?" 106 The Rules Committee nonetheless recommended the amendment to the New Mexico Supreme Court, which adopted it effective in December of 2000. ${ }^{107}$

In both New Mexico and Vermont, the rulemaking committees commented on their intent to copy ${ }^{108}$ or "incorporate" 109 the federal rule. In Vermont, the Reporter's Notes regarding that state's 2002 adoption of Rule 23(f) included extended excerpts from the Federal Rule 23(f) Advisory Committee's Note, and concluded by pointing out the statutory provision "giving the [Vermont] Supreme Court power to hear and make rules for appeals before final judgment on questions of law."110

Illinois has the most remarkable rulemaking story of the amending states. In 2002, the Illinois Supreme Court issued a press release announcing the addition of class action certification rulings to the list of orders appealable at the discretion of the appellate courts. ${ }^{111}$ The Court noted that under existing law, such orders were "not appealable until the trial of the law suit is completed, often a long process that consumes

class certification rule to reflect FRCP 23's 1998 amendment”).

105. See Letter from J.E. Gallegos and Michael P. Gross to Kathleen J. Gibson, Clerk, New Mexico Supreme Court 1 (June 9, 2000) (on file with author).

106. See Letter from Lynn Pickard, Chief Judge, State of New Mexico Court of Appeals, to Kathleen J. Gibson, Clerk, New Mexico Supreme Court (May 22, 2000) (on file with author).

107. See N.M. R. CIV. P. 1-023(f); see also Letter from William P. Lynch, Chair, Rules of Civil Procedure Committee, to Pamela B. Minzner, Chief Justice, New Mexico Supreme Court (September 7, 2000) (reporting on the completion of the committee's review of 1-023(f) and noting that the committee "continues to recommend" the rule's adoption) (on file with author).

108. See Letter from William P. Lynch, Chair, Rules of Civil Procedure Committee, to Pamela B. Minzner, Chief Justice, New Mexico Supreme Court (April 25, 2000) (recommending adoption of Rule 23(f)) (on file with author).

109. See VT. R. Civ. P. 23(f) reporter's notes ("Rule 23(f) is added to incorporate Federal Rule 23(f) ....").

110. See id.; see also VT. STAT. AnN. tit. $12 \S 2386$ (2007).

111. See Press Release, Illinois Supreme Court, Illinois Supreme Court Allows Early Appeal in Class Action Suits, Nov. 27, 2002 [hereinafter 2002 Press Release], http://www.state.il.us /court/Media/PressRel/2002Rel.asp; see also Press Release, Illinois Supreme Court, Supreme Court Allows Early Appeals on Class Certification, Jan. 3, 2003, http://www.state.il.us/court/Media /PressRel/2003Rel.asp (clarifying new rule); ILL. S. CT. R. 306(a)(8) (amended Dec. 31, 2002). 
court resources and financial and other resources of the parties."112 The Chief Justice explained that "“[t]he Court agreed that this would be helpful to litigants as well as to those who practice in this area, and that such a rule is fair to all sides.", "113 The press release further approvingly noted that the U.S. Supreme Court had "adopted a similar amendment" affecting federal class action practice after "lengthy hearings and comment over several years."

Illinois's appellate rule change occurred after that state's inclusion on the American Tort Reform Association's 2002 notorious list of the nation's “Judicial Hellholes," due in large part to its class action practices. ${ }^{115}$ The change also came on the heels of repeatedly thwarted efforts in the state's legislature to statutorily provide the right to immediate appeal of class certification orders. ${ }^{116}$ One member of the Court wrote a strong dissent from the order adopting the new rule, complaining about the Court's "almost immediate[]" adoption of the rule after receiving "a proposal from a proponent," particularly in light of the legislative history. ${ }^{117}$ The dissenting justice criticized the Court's action as an unwarranted departure from its usual rulemaking practices:

To justify this abbreviated amendment procedure, the majority would likely explain that the rule is harmless, applying equally to plaintiffs and defendants, and simply follows the federal rule. Although that rationale and other reasonable rationales may be correct, the adoption of the amendment without public notice, comment, and thoughtful deliberations by our Rules Committee runs afoul of our established rulemaking process for litigation matters. This amendment is not merely an administrative rule; rather it is a rule directly affecting the course of litigation. ${ }^{118}$

112. See 2002 Press Release, supra note 111 (quoting Chief Justice Mary Ann G. McMorrow).

113. Id.

114. Id.

115. See Am. Tort Reform Ass'N, Bringing Justice to Judicial Hellholes 2002, at 7 http://www.atra.org/reports/hellholes/2002/hellholes_report_2002.pdf. (alleging that class action filings in Madison County, Illinois increased by 1850\% between 1998-2000 (citing John H. Beisner \& Jessica Davidson Miller, They're Making A Federal Case Out of It . . in State Court, 25 HARV. J.L. \& PUB. POL’Y 143, 160 (2001))).

116. See e.g, S. 1920, 91st General Assembly, Regular Session (Ill. 1999-2000) (allowing class action litigants "an absolute right to appeal the circuit court's decision granting or denying class action certification”); Daniel C. Vock, Justices Rewrite Rule on Class Certification, CHI. DAILY L. BuLL., Jan. 2, 2003 (reporting the Illinois Trial Lawyers Association's description of the rule as "a big victory for corporations and insurance companies," and noting that the latter "have sought similar changes in the General Assembly for three years").

117. See ILL. S. CT. R. 306(a)(8) (Kilbride, J., dissenting) (amended Dec. 31, 2002).

118. Id. 
The next round of state class action appellate changes occurred legislatively. ${ }^{119}$ Colorado's legislature, which ordinarily delegates rulemaking functions to its Supreme Court, enacted a bill in 2003 allowing class litigants to seek interlocutory discretionary review from the Court of Appeals. ${ }^{120}$ Until that year, an order denying class certification could be appealed as final judgments if the district court agreed to certify its order under Colorado's Rule 54(b), ${ }^{121}$ but an order granting class certification was not immediately appealable. ${ }^{122}$

The Colorado Legislature chose to follow the federal lead, allowing appeals at the discretion of the appellate court. The chief imperative seems to have been a desire to expand defendants' appellate opportunities in the face of certified class actions: the bill's sponsor in the Senate spoke of the "pressure on defendants to settle" because defendants otherwise have to "wait until final judgment has been rendered in order to appeal." "allow quick appeals to determine whether a class action lawsuit is appropriate" was among a "flurry of bills to limit lawsuits and damage awards ... flying through the legislature" that year. ${ }^{124}$

Georgia's class action practices during this period changed the most significantly (and the most often) of any state. Prior to 2003, Georgia

119. Although I do not include Texas as an amending state because its statute providing appellate review as of right for all class certification orders pre-dated Federal Rule 23(f) by almost twenty years, Texas did alter its class action appellate rules in 2003. In that year, as part of an extensive set of revisions to its class action rule that in many respects followed that year's amendments to Federal Rule 23, the Texas Legislature further provided class litigants the right to petition the Texas Supreme Court directly from a district court certification order. See § 1.02(d), 2003 TEX. GEN. LAws page no. 850, codified at TEX. Gov’T CODE ANN. § 22.225(d) (Vernon 2004).

120. See H. 03-1027, 64th Gen. Assem., 1st Reg. Sess. (Colo. 2003), codified at COLO. REV. STAT. § 13-20-901 (2005).

121. See Levine v. Empire Sav. \& Loan Ass’n, 557 P.2d 386, 387 (Colo. 1976) (en banc); see also COLO. R. CIV. P. 54(b) (requiring an express determination by the district court "that there is no just reason for delay,” and “an express direction for the entry of judgment”).

122. See Soto v. Progressive Mountain Ins. Co., 181 P.3d 297, 300 (Colo. App. 2007) (concluding that pre-2003, "no Colorado cases... hold an order granting class certification is subject to interlocutory appeal”).

123. Senate Committee on Judiciary, Bill Summary for H.B. 03-1027 (Colo. Mar. 3, 2003). The only witness to testify at the Senate hearing, and the only two witnesses to testify at the House Committee hearing on the bill, spoke in support of the bill. See id.; House Committee on Business \& Labor, Bill Summary for H.B. 03-1027 (Colo. Jan. 16, 2003).

124. See Arthur Kane, Bills Target Lawsuits, Damage Awards: A Dozen Measures Would Limit Payouts, Denver Post, Apr. 6, 2003, at B1. The Colorado Supreme Court, through its rules committee, amended its Rule 23 that same year to add an (f) provision that merely referenced the new appellate statute, electing not to follow the language of the federal rule. See Colorado Supreme Court Rules Committee, Minutes of Meeting and attachments (August 22, 2003) (on file with author); see also CoL. R. CIV. P. 23(f) (amended nunc pro tunc July 1, 2003). 
still adhered to the pre-1966 version of Federal Rule 23. ${ }^{125}$ In 2003, however, the Georgia General Assembly rewrote the state's class rule in its entirety, replacing it with the version of Federal Rule 23 then in effect. $^{126}$ The bill's summary highlighted the addition of the federal rule's provision allowing for "a discretionary immediate appeal, which existing state law did not allow."127 The bill's chief sponsor in the Senate explained that the impetus behind the bill originated from representatives of several major Georgia corporations well aware of the potential significance to them of CAFA's likely passage. ${ }^{128}$ Given CAFA's jurisdictional carve-outs denying a federal forum for mass actions brought by large numbers of in-state plaintiffs against in-state defendants, Georgia-based companies wanted to ensure that Georgia's state class action rule mirrored the federal rule and specifically provided the protection of immediate appellate review. ${ }^{129}$ The original Senate bill included additional provisions based on Alabama's statute, such as the requirement of a full evidentiary class certification hearing and class appeals as of right, ${ }^{130}$ but the final bill, enacted in 2003, followed Rule 23(f)'s discretionary appellate review language. ${ }^{131}$

In 2004, Kansas and Missouri statutorily adopted discretionary rules, altering class certification appellate landscapes that otherwise closely resembled the pre-Rule 23(f) scene in federal courts. The Kansas Legislature followed its usual statutory rulemaking process, holding hearings in both houses on a bill that tracked Federal Rule 23(f) almost to the word. ${ }^{132}$ Indeed, a law professor who appeared in support of the

125. See Freer, supra note 40, at 22.

126. See H. 792, 2003 Leg., Reg. Sess. (Ga. 2003), codified at GA. CoDE ANN. § 9-11-23 (2003); see also Ashley S. Harris, Crystal Ferrier, \& Andrew S. Lewinter, Civil Practice Act, 20 GA. ST. U. L. REV. 28, 33-39 (2003) (detailing bill's legislative history).

127. Harris et al., supra note 126, at 28.

128. Id. at 29-30.

129. See id. at 30 .

130. Id. at 30-31.

131. Id. at 36. The bill easily passed both houses, with only a handful of votes against it and several abstentions. See id. (noting that the bill passed both the House and the Senate between 10:00 p.m. and midnight on the 40th and last day of Georgia's legislative session); see also Georgia General Assembly, HB 792: Bill History, available at http://www.legis.ga.gov/legis/200304/sum/hb792.htm (last visited Apr. 13, 2010) (recording legislative history and vote tallies). The class action bill was expanded considerably by the end of its consideration. It included provisions allowing Georgia courts to vacate arbitration awards, changed pre- and post-judgment interest rules on civil damage awards, placed limits on the number of times plaintiffs could voluntarily dismiss a claim, and gave courts greater discretion to deny jurisdiction in actions involving out-of-state defendants. See H. 792, 2003 Leg. Reg. Sess. (Ga. 2003) (codified at GA. CoDE ANN. §§ 7-4-12, 99-13, 9-11-41, 50-2-21, 51-12-14, -71, -72 (2003)).

132. See H. 2764, 80th Leg., Reg. Sess. (Kan. 2004) (codified at Kans. Stat. 60-223(f)). Testimony in support of the legislation was given by representatives from the Kansas Chamber of 
proposed appellate change testified that "absent compelling reasons, the Kansas rules of civil procedure should mirror the Federal Rules of Civil Procedure.”133 That same year, the Missouri General Assembly included a provision for the discretionary review of class certification orders in a bill addressing a wide range of matters relating to court procedures, such as court fees and jury duty procedures. ${ }^{134}$

In 2005, the year Congress finally passed CAFA, Georgia, Tennessee, Louisiana and Minnesota all acted to amend their state class action appeals rules. Two years and (apparently) no appeals after its 2003 statute, ${ }^{135}$ Georgia's General Assembly returned its attention to the state's class action appellate practices. This time around, legislators who had previously advocated on behalf of Georgia's corporate community ${ }^{136}$ prevailed in securing a right to immediate appellate review of class certification orders. $^{137}$ Indeed, analyzing the impact of CAFA on Georgia class actions, an experienced class action plaintiffs' attorney noted that the state's provision of a right to appeal, as opposed to the discretionary review offered in federal courts, "makes class litigation in Georgia state courts somewhat less attractive than might otherwise be the case." 138

Commerce, the Kansas Civil Law Forum, a practicing attorney, and the dean of the Washburn University School of Law. See Minutes of the House Judiciary Committee: Hearing on HB 2764, 80th Leg. 1 (2004); Minutes of the Senate Judiciary Committee: Hearing on HB 2764, 80th Leg. 2 (2004).

133. See Minutes of the Senate Judiciary Committee, supra note 132, at 2 (testimony of Professor James Concannon, Washburn University).

134. S. 1211, 92nd Gen. Assem., Reg. Sess. (Mo. 2004). Two years later, the Missouri Supreme Court amended its class action rule to include the discretionary appeal provision mandated by the 2004 statute. Mo. SuP. CT. R. 52.08(f) (amended June 21, 2005).

135. See Freer, supra note 40, at 22.

136. See State Chamber Focusing on Preserving Pro-Business Climate in Georgia, MEtropolitan Corp. COUNS. (SPECIAL RePORT: THE SOUTHEAST), Apr. 1, 2009, at 55 (describing Georgia's 2005 adoption of “a package of legal and civil justice reforms,” including the class action appeals legislation, and "an omnibus tort reform bill”). Indeed, as in 2003, The Atlanta JournalConstitution reported that the bill expanding class action appellate opportunities was not the only "pro-business" accomplishment of a legislative session the Georgia Chamber of Commerce gleefully described as an "extra-extraordinary" one for the "business community." See James C. Cobb, As Biz Basks in Hotlanta, Folks Feel Chill, AtlantA J.-Const., Apr. 5, 2005, at A19.

137. See S. 19, 148th Gen. Assem., Reg. Sess. 2005 Regular Session (Ga. 2005) (enacted). Members of the plaintiffs' bar had opposed the change, charging that it unduly favored defendants. See S. 148-5, Reg. Sess., at 5 (Ga. 2005) (reporting that representatives from Southwire Corporation, the Georgia Chamber of Commerce and Southeastern Legal Foundation testified in favor of the bill, while a representative of the Georgia Trial Lawyers Association testified against it).

138. See Carr, supra note 60. The President of Georgia's Chamber of Commerce later praised the additional protection offered by the statutory appellate right, noting that after seeing "a growing number of class action suits in Georgia ... our companies have been able to take advantage of this new law and protect their assets and their stockholders from needless negative impact." See METROPOLITAN CORP. COUNS., supra note 136. 
With little fanfare, the Tennessee General Assembly also changed its class action appellate rules in 2005. Prior to that year, the Tennessee Supreme Court had limited review of class certification orders to either an extraordinary appeal or one granted by permission of both the trial and the appellate courts. ${ }^{139}$ Reasoning by analogy to Coopers, the Court had also refused to allow a plaintiff's right to appeal an order denying class certification even with a trial court's Rule 54(b) entry of final judgment. ${ }^{140}$ Tennessee's statute tracked the substance of Federal Rule 23(f), allowing appeals at the sole discretion of the appellate courts. ${ }^{141}$

The Minnesota Supreme Court also revised its class action rule in 2005, largely incorporating the Federal Rule 23 amendments of both 1998 and 2003. ${ }^{142}$ The addition of Minnesota's version of Rule 23(f), as the Supreme Court's Advisory Committee Comment observed, effected little change in the appealability of class certification orders in the state because Minnesota's appellate courts already permitted discretionary review of such orders pursuant to a generic discretionary appeal rule. ${ }^{143}$

As in Minnesota, the change in Louisiana's class action appeals rules also seems to have reflected more a codification of existing rights rather than a significant expansion of those rights. Louisiana already allowed class certification orders to be reviewed via its supervisory writ procedure, ${ }^{144}$ and the Louisiana Supreme Court had interpreted a statute permitting appeals as of right from orders causing "irreparable injury" to include class certification orders. ${ }^{145}$ But in 2005, the Louisiana Legislature passed a statute that specifically codified the appealability of class certification orders. ${ }^{146}$

139. See TenN. R. ApP. P. 9 \& 10; see also Meighan v. U.S. Sprint Comm’ns Co., 924 S.W.2d 632, 635 (Tenn. 1997) (granting both extraordinary and interlocutory appeal of order certifying class).

140. See Bayberry Assocs. v. Jones, 783 S.W.2d 553, 557-59 (Tenn. 1990).

141. Act of May 28, 2005 ch. 280, § 1, 2005 Tenn. Pub. Acts 496-97 (amending appeals procedure (codified at TENN. CODE. ANN. § 27-1-125 (2005)).

142. See MinN. R. Civ. P. 23, advisory committee's cmt. to 2006 Amendment, available at 48 MinN. StAT. ANN. at 281 (2006) (amended November 30, 2005) (noting that the amendments "extensively revamped" Rule 23, and "primarily adopt the amendments made to federal rule 23 in 2003”).

143. Id. at 282 (citing Gordon v. Microsoft Corp., 645 N.W.2d 393 (Minn. 2002)).

144. See Hamilton Med. Group v. Ochsner Health Plan, 550 So. 2d 290, 292 (La. Ct. App. 1989) (rendering decision on a supervisory writ application in a challenge based on improper venue).

145. See Davis v. Jazz Casino Co., 849 So. 2d 497, 498 (La. 2003); Carr v. GAF, Inc., 702 So. 2d 1384, 1385 (La. 1997).

146. 2005 La. Acts 1475-76 (codified at La. Code Civ. Proc AnN. ART. 592(A)(3)(b)). The statute also provided class litigants the right to request from the trial court detailed findings of fact and law following any certification decision. See id. 
The last two amending states, Indiana and Montana, amended their appellate rules in 2007 to include class action specific provisions. Prior to that year, class certification orders had been held by Indiana's Supreme Court to be interlocutory and not immediately appealable absent the trial court's entry of final judgment pursuant to Indiana Rule 54(b). ${ }^{147}$ In 2007, however, after a public comment period and on the recommendation of its rules committee, the Indiana Supreme Court exercised its rulemaking and "inherent authority to supervise the administration of all courts of this state" by amending its appellate procedure rules to provide discretionary appeals from interlocutory orders "granting or denying class certification” under Indiana's Rule $23 .^{148}$

Unlike Indiana, which followed the federal policy of discretionary class appeals, Montana altered its appellate rules to provide an appeal as of right for all class certification orders. Montana had long provided an appeal as of right to rejected class plaintiffs, but it had not extended that same appellate access to defendants faced with certified classes. ${ }^{149}$ After a comment period and public meetings, the Montana Supreme Court in 2007 adopted several amendments to its appellate rule, including appeals from orders "permitting or refusing to permit an action to be maintained as a class action."

\section{MAKING SENSE OF STATE EXPANSIONS OF ClAsS CERTIFICATION APPEALS: THE REPLICA THEORY AND THE INTEREST GROUP THEORY}

This Part explores two principal hypotheses in an attempt to shed light on why states might have amended their rules to expand class litigant access to interlocutory appellate review. First, given the marked uptick in state changes in the wake of Rule 23(f), ${ }^{151}$ this part considers

147. See Martin v. Amoco Oil Co., 696 N.E.2d 383, 385-86 (Ind. 1998). The Martin Court overruled a line of intermediate appellate court decisions finding such orders to be final and appealable. See, e.g., American Cynamid Co. v. Stephen, 600 N.E.2d 1387, 1387 (Ind. Ct. App. 1992).

148. Indiana Supreme Court Order No. $94 \mathrm{~S} 00$ (2008) (amending Rules of Appellate Procedure); IND. R. APP. P. 14(C)

149. See State ex. rel. Anaconda Aluminum Co. v. Dist. Ct., 490 P.2d 351, 352 (Mont. 1971) (explaining that although appeals as of right from denials of class certification were expressly included in appellate rule 23, the 1967 Advisory Committee's Note to that rule made clear that "[t]here does not seem to be a corresponding necessity for direct appeal" from orders granting class certification)

150. MonT. R. App. P. 6(3)(d) (enacted by Supreme Court Order No. AF 07-0016 (2007)).

151. See supra Figure 1. 
whether the increase in access to state appellate courts can best be explained as resulting from a continuing preference among some states to track changes in the Federal Rules. Second, it examines whether such state appellate developments instead reflect the pressures political interest groups have brought to bear in certain targeted states. Even if Federal Rule 23(f) itself was arguably a non-partisan, neutral rule, state rulemaking processes may be more susceptible to interest group influences, ${ }^{152}$ perhaps particularly in the post-CAFA era. I refer to these theories as the "Replica Theory" and the "Interest Group Theory," and test each in several ways.

First, I look to the number of states in each category that as of July 1, 1998, imposed limits on class action appeals, ${ }^{153}$ measuring the percentage of those states that then amended to expand their class action appellate rules. ${ }^{154}$ I then compare the resulting rate of states that amended in each category to determine if the categorization applied helps to explain which states chose to amend. Second, I consider the percentage of states in each category that "pre-amendment" (as of July 1, 1998) already had expansive class action appellate rules (either by the sole discretion of the appeals courts or as of right), and compare that to the percentage of states in each category that provide such appellate rights as of today, which I refer to as the "post-amendment" status of those states (as of July 1, 2009). This measure may help to explain why states in some categories might have been less likely to amend in the first instance: they already provided appellate rights that were the equivalent of Rule 23(f) or, in many cases, greater class litigant access to interlocutory review by authorizing such appeals as of right.

As discussed in the introduction, the data that follow permit only qualified conclusions. The small sample sizes of states in various categories, in particular, may exaggerate apparent results. Moreover, although I have attempted to account for confounding variables where possible, I did not conduct multivariate regression analyses. As detailed

152. Cf. Richard Marcus, Not Dead Yet, 61 OKLA. L. Rev. 299, 314 (2008) (noting that "despite lobbying, the [federal] rulemaking process has not displayed anything like the sorts of partisan or otherwise political traits that one would find in ... a state legislature").

153. See supra Table 1. In addition to state appellate limits comparable to the pre-Rule 23(f) federal court limits, recall that several states at this time only permitted appeals for plaintiffs denied the opportunity to pursue litigation on a class action basis. Those states, which required defendants challenging a class certification order to do so via extraordinary appellate review, are included in my definition of "States With Limited Interlocutory Appeals." See supra note 73 and accompanying text.

154. Two states, Minnesota and Louisiana, amended their class action rules in a manner each described as reflecting a codification of preexisting appellate rights. These amending states are considered in both measures to be states that already provided expanded appellate rights. 
in Part III, each state's unique amendment experience involved an array of factors difficult to untangle: the state's prior appellate treatment of class certification orders, the rulemaking process (judicial or legislative) by which a state adopted the new appellate jurisdictional rule, the scope of the appellate rights extended to class litigants, the state's population and political makeup, the interrelationship among each state's judicial, legislative and executive branches, the presence or history of interest group influences, the extent to which the state's class action practices may have been influenced by federal class action law generally, and the nature of class action activity in each state. And these confounding variables were often even more difficult to examine in the control group of states that still limit appellate access for class litigants. Finally, this article is the first part of a larger and ongoing research project, so any conclusions are necessarily provisional and preliminary. The data, however, do reveal some interesting results and permit some conclusions, albeit tentative ones.

\section{A. The Replica Theory}

Judge Charles E. Clark, the principal drafter of the Federal Rules, expressed his fond hope that a thoughtful set of uniform federal rules could serve as "a model to all the states." 155 In the decades following the adoption of the Federal Rules, a majority of states did indeed amend their procedural rules to replicate the federal provisions, in broad measure if not in virtual lockstep. ${ }^{156}$ Judge Clark followed such state adoptions closely and reported them "with paternal pride." 157 Professor Charles Alan Wright carried on the work of surveying state procedural systems

155. Charles E. Clark \& James WM. Moore, A New Federal Civil Procedure, 44 YaLE L. J. 387, 387 (1935); see also Thomas O. Main, Procedural Uniformity and the Exaggerated Role of Rules: A Survey of Intra-State Uniformity in Three States That Have Not Adopted the Federal Rules of Civil Procedure, 46 VILL. L. REV. 311, 320 (2001) (describing belief at the time of the Rules Enabling Act that "the Federal Rules would be so enlightened and simple that intra-state uniformity would follow naturally as states voluntarily adopted the federal model"); Subrin, supra note 7, at 80 (describing Rules Enabling Act advocates' view that the superiority of the Federal Rules would make the states "see the light and follow suit"); Stephen N. Subrin, Federal Rules, Local Rules, and State Rules: Uniformity, Divergence, and Emerging Procedural Patterns, 137 U. PA. L. REV. 1999, 2002-06 (1989).

156. See John B. Oakley \& Arthur F. Coon, The Federal Rules in State Courts: A Survey of State Court Systems of Civil Procedure, 61 WASH. L. REV. 1367, 1367-69 (1986).

157. Id. at 1368 n. 7. Indeed, even before the promulgation of Federal Rules, Judge Clark cheered the increasing number of state adoptions of code pleading procedural systems, both as a policy matter and because of his belief in the value of uniform procedural systems. See id. (citing CLARK, HANDBOOK OF THE LAW OF CODE PLEADING 19-20 (1928)). 
and the influence of the Federal Rules model, confirming in 1960 an "accelerating trend in the states toward adoption of the federal rules." 158

The experience in Arizona, the first state to adopt the Federal Rules, illustrates why some states might be inclined to adopt federal procedural rules. Those in favor of adopting the federal rules in Arizona cited the low costs and many benefits of replication. ${ }^{159}$ Arizona's comparatively small rulemaking resources could hardly match those of the Supreme Court, with its cadre of experts and a lengthy process encompassing the views of lawyers nationwide. ${ }^{160}$ And not only would the resulting product of such expertise likely be of good quality, local lawyers familiar with the same set of rules could "feel at home" in any federal court throughout the country. ${ }^{161}$

The replication trend had "slowed to a creep" by 1986, however, when a comprehensive survey of state procedural laws revealed that less than half the states could then be characterized as "true federal replicas."162 Moreover, even "when a looser test than replication was applied to classify states as generally following the model of the Federal Rules, the resulting tally embraced a majority of states but a minority of our national population."163 In other words, the survey found a correlation between states inclined to adopt the federal rules and those with the smallest populations. ${ }^{164}$ The most populous states, on the other hand, were more likely to resist replication, "stick[ing] to their procedural guns.”165 And, in the last few decades even replica states

158. 1 William W. Barron \& Alexander Holtzoff, Federal Practice and Procedure WITH FORMS foreword at iii (Charles Alan Wright ed. 1960); see id. at 43-46 (given the superiority of the Federal Rules, "the proponents of uniform state rules of procedure patterned on the federal rules make a strong case”); see also Oakley \& Coon, supra note 156, at 1367 (“Then barely two decades old, the Federal Rules appeared to be the harbinger of substantial uniformity in American civil procedure.”).

159. See Subrin, supra note 155, at 2026-28 (citing Allen, The New Rules in Arizona, 16 F.R.D. 183, 184 (1954)); cf. 1 Conn. Practice Book, Super. Ct. Civ. Rules § 9-8 (2009) (adopting Federal Rule 23 in Connecticut, where "class action litigation is rare . . . and the resulting body of state case law is light," allows that state "to access useful case law from thirty three states and the District of Columbia, all of which have adopted [Fed. R. Civ. P. 23] or some variation of it”).

160. See Subrin, supra note 155, at 2026-28. Other western states with fairly low populations, Colorado, New Mexico and Utah, followed suit shortly after Arizona. Id. at 2028.

161. Id. at 2027 (citing Lyle Roger Allen, The New Rules in Arizona, 16 F.R.D. 183, 184 (1954)).

162. Oakley \& Coon, supra note 156, at 1369; see also Oakley, supra note 7, at 358-59 (explaining that after 1975, the pace of both "true" federal rule replication and procedural reforms in the general direction of the federal model grounded "almost to a halt").

163. Oakley \& Coon, supra note 156, at 1369.

164. Id. at 1426 (concluding that "systematic state court affinity for the Federal Rules is heavily concentrated among the less populous states”).

165. See Subrin, supra note 155, at 2044-45; see also Seymour Moskowitz, Discovery in State 
have increasingly demonstrated a willingness to deviate from the federal model. ${ }^{166}$

The Replica Theory, then, requires an examination of the degree to which a state's replica status might explain its adoption of Rule 23(f), or the amendment of its rules to effectively expand appellate access for class litigants. I begin testing the Replica Theory by examining the extent to which "replica" states, variously defined, have amended their class action appellate rules.

A state's replica status may best be gauged by whether its class action rule at the time of Rule 23(f) already generally replicated Federal Rule 23 (what I call "Replica Rule 23 states"), surely the most obvious sign of a state's interest in mirroring federal class action practices. ${ }^{167}$ Alternatively, I define replica states as those states identified by Professor John Oakley as basing their state procedural rules on the Federal Rules as a whole. ${ }^{168}$ The Replica Theory here suggests that states generally adopting the Federal Rules would be more disposed to amend their rules to track federal changes to those rules than states that had never adopted the Federal Rules in the first place. I next examine the extent to which states that generally adopted the Federal Rules later amended their rules to adopt various non-class action federal rule amendments. The Replica Theory here would predict that states with high adoption rates of subsequent federal amendments would be more likely to adopt Rule 23(f) than replica states whose low adoption rate of new federal amendments may suggest an increasing unwillingness to follow the federal lead. Finally, I examine the possible "replica" effect of a state's inclination to model its rules not necessarily on parallel federal rules but rather those of its sister states. ${ }^{169}$ This measure of a replica effect is particularly difficult to measure, but the Replica Theory would suggest a correlation between a state's likelihood of adopting uniform state laws and its likelihood of amending its class action rules to expand appellate access.

Civil Procedure: The National Perspective, 35 W. St. U. L. REv. 121, 28 (2007) (praising the innovative discovery reforms in "states with large populations and high volume courts").

166. See, e.g., Seymour Moskowitz, Rediscovering Discovery: State Procedural Rules and the Level Playing Field, 54 RUTGERs L. REV. 595, 647 (2002) (speculating that recent state discovery innovations and experiments "may be the harbinger of a future procedural regime").

167. Cf. 1 Conn. Practice Book, Super. Ct. Civ. Rules § 9-8 (adopting current version of Federal Rule 23 "with minor variations" to enable Connecticut courts and litigants to more predictably rely on precedents interpreting Federal Rule 23).

168. See Oakley, supra note 7, at 355-58; see also Oakley \& Coon, supra note 156, at 1372-78.

169. See, e.g., Koppel, supra note 7, at 1194-1201 (extolling the benefits to be gained by states coordinating with each other to achieve interstate procedural uniformity). 


\section{Replica Federal Rule 23 States}

To study the correlation between replica Federal Rule 23 states and states that amended their appellate rules with respect to class certification orders, I categorized each of the 49 jurisdictions with a general class action rule as either a "replica Rule 23" state or a "variant class action" state. This methodology examined each state's class action rule as of 1998, characterizing as a "replica Rule 23" state one with judicially or statutorily codified rules that either copied the 1966 version of Federal Rule 23 verbatim or did so with only slight modifications. ${ }^{170}$ I categorized states that eliminated or merged significant provisions of the Federal Rule ${ }^{171}$ or maintained the pre-1966 version of Federal Rule $23^{172}$ as "variant class action" states. The variant category also includes states whose class action rules more dramatically deviated from Federal Rule 23, such as those based on the Field Code ${ }^{173}$ or the Uniform Class Actions Act. ${ }^{174}$

With respect to the replica Rule 23 category, I found that $50 \%$ of replica Rule 23 states expanded class action litigant access to interlocutory review in the wake of the amendment of Federal Rule 23(f). On the other hand, only $20 \%$ of states with variant class action rules did so in the same period. The data in Figure 4, however, suggest that the lower amendment rate for variant class action rule states may at least partly be a function of the fact that a greater percentage of variant class action rule states than replica Rule 23 states already had class action interlocutory appeals. As shown in Figure 4, 52\% of "variant class action" states already provided interlocutory appeals of class certification orders pre-Rule 23(f), and $62 \%$ of variant class action states now allow such appeals. On the other hand, only $21 \%$ of replica Rule 23 states permitted such appeals pre-Rule 23(f), rising to $61 \%$ of replica Rule 23

170. See Rowe, supra note 77, at 147-48 (observing that "a considerable majority of American states track Federal Rule 23, at least in its 1966 version . . closely and in a good many cases word for word").

171. See, e.g., id. at 153 (citing Illinois's omission of the typicality requirement); id. at 156 (citing New Hampshire and South Carolina's omission of Federal Rule 23(b) counterparts); id. at 157-58 (citing Oregon and Pennsylvania as states that treat predominance as only one consideration in a "multi-factor list").

172. See id. at 149-50 (discussing North Carolina's adherence to the original Federal Rule 23). In 1998, Georgia also still remained in this category, although it later adopted the 1966 version of Rule 23. See Freer, supra note 40, at 22; supra notes 125-26 and accompanying text.

173. See, e.g., CAL. Civ. Proc. CodE § 382 (West 2009); NeB. ReV. StAT. § 25-319 (2009); Wis. STAT. ANN. § 803.08 (2009); Rowe, supra note 77, at 149.

174. See Rowe, supra note 77, at 150 (describing the Uniform Class Actions Act or Model Class Action Rule promulgated in 1976 by the National Conference of Commissioners on Uniform State Laws, thus far adopted only by Iowa and North Dakota). 
states today. At the end of the day, then, the percentage of states that now provide expanded interlocutory appeal rights for class litigants is virtually the same between replica Rule 23 states (61\%) and variant class action states (62\%).

\section{Figure 4: Availability of Interlocutory Appeals, By Federal Rule 23 Replica Status}

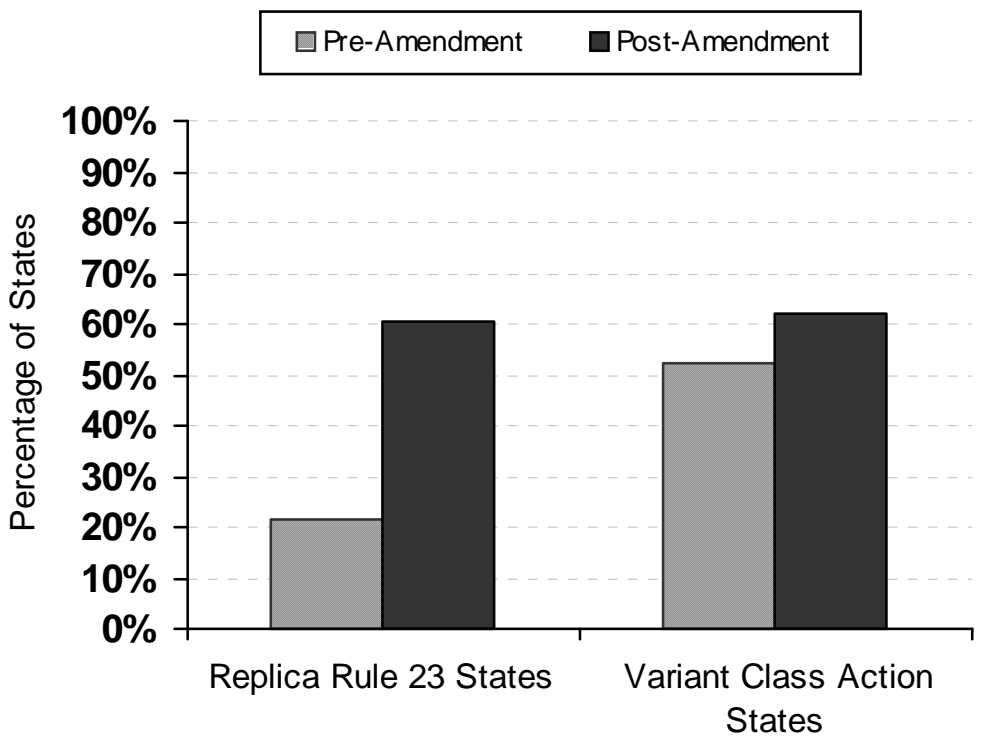

Despite this apparent parity, it seems nonetheless significant that fully half of the replica Rule 23 states chose to amend their class action rules to expand appellate rights in the wake of Rule 23(f), perhaps especially so given the low percentage of replica Rule 23 states that provided such appellate rights before Rule 23(f). Post-Rule 23(f), then, half of the replica states that had previously tracked federal court limits on class action appeals similarly moved in the direction of the federal rule to provide expanded appellate access for class litigants. On the other hand, $80 \%$ of variant class action states that could have amended their class action procedures to expand appellate access failed to do so, even though variant class action states as a whole were far more likely to provide such appeals in the pre-Rule 23(f) world.

When one looks more closely at the replica Rule 23 states, however, that $50 \%$ amendment rate may exaggerate the degree of replication. While eleven out of twenty-two replica Rule 23 states indeed amended post-Rule 23(f), only eight states did so in true synchronicity with Rule 23(f) itself, authorizing appellate courts the unilateral discretion to 
review class certification orders. Three of the eleven states (27\%) that amended their class appellate rules post-Rule 23(f) did not replicate the federal approach, instead providing automatic appeals of class certification orders as a matter of right. This non-conformity among socalled "replica" states brings the percentage of states that amended postRule 23(f) in actual conformity with the federal rule down to 36\%, with $14 \%$ of the replica Rule 23 states expanding appellate access far more dramatically than the federal approach allows. ${ }^{175}$

\section{Replica Federal Rules States}

Professor John Oakley, following in the footsteps of Judge Clark and Charles Alan Wright before him, conducted two comprehensive surveys of state procedural rules evaluating relative degrees of federal rules replication. ${ }^{176}$ In his seminal 1986 work, co-authored by Arthur Coon, Professor Oakley painstakingly analyzed each state and determined its proper replica category, including "true" federal rules replica states; ${ }^{177}$ those that largely replicated the federal rules but did so by statute rather than by judicially promulgated rule; ${ }^{178}$ and those with a "strong affinity" to the federal rules but that nevertheless fell slightly short of "true" replica status. ${ }^{179}$

The Replica Theory would suggest that states Professor Oakley identified in 1986 as "replica" states, including all the categories listed above, would be more likely than non-replica states to amend their class action appellate rules to track Federal Rule 23(f). ${ }^{180}$ This list has much overlap with the list of "replica Rule 23" states I created above, but also includes states whose state procedural rules tracked the content and organization of the federal rules overall, but which did not have a class action rule that reflected the major 1966 overhaul of Rule $23 .{ }^{181}$

175. Indeed, Judge Scirica, on behalf of the Judicial Conference Committee on Rules of Practice and Procedure, argued fiercely against class appeals as of right in federal courts on the ground that automatic appeals would substantially undermine the carefully crafted procedural policies reflected in Rule 23(f). See supra notes 66-69 and accompanying text.

176. See Oakley \& Coon, supra note 156; Oakley, supra note 7.

177. See Oakley \& Coon, supra note 156, at 1377 (referring to this as "our cardinal classification”).

178. Id. at 1378 (citing Kansas, Georgia, North Carolina, and Oklahoma in this category).

179. Id. at 1377-78. Included in this category are Arkansas, Delaware, and South Carolina, which used a "higher standard of factual specificity in pleading," as well as Idaho and Nevada, whose largely replicating rules fail some Oakley/Coon criterion for "true” replication. Id.

180. See id. (describing non-replica states that adopted either an "Idiosyncratic Rules-Based Procedural Systems” or “Fact Pleading/Code-Based Procedural System”).

181. Georgia, North Dakota, and North Carolina all fit this description. 
Figure 5: Availability of Interlocutory Appeals, By FRCP Replica Status

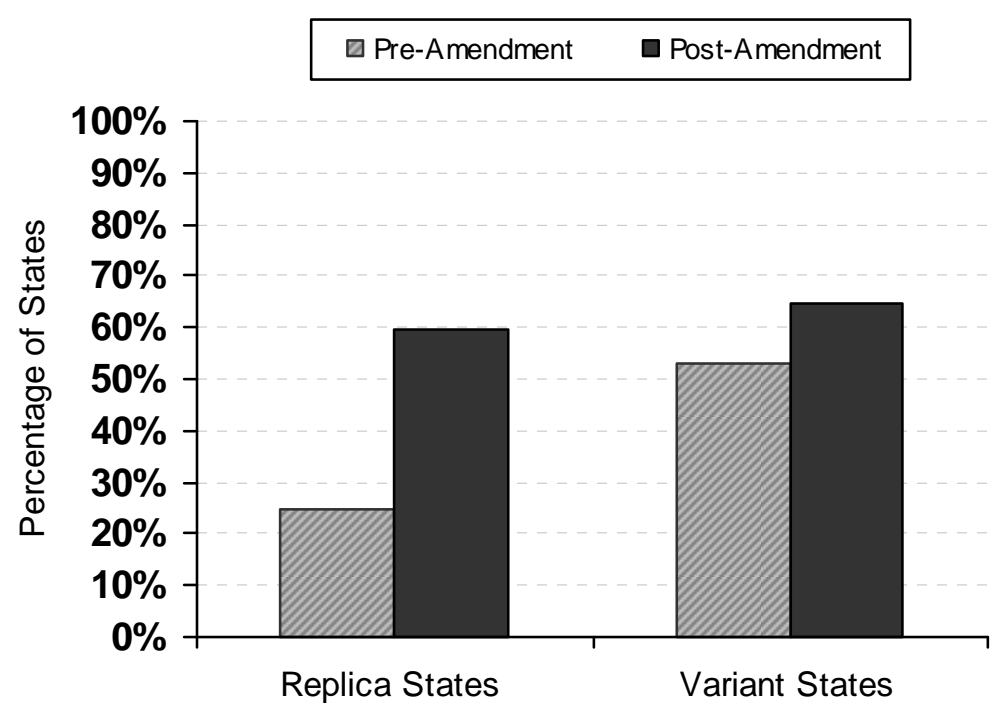

Comparing relative rates of amendment for the two Oakley categories, I found that $46 \%$ of replica federal rules states amended postRule 23(f), while only $25 \%$ of variant rules states did the same. These numbers are quite similar to the replica Rule 23 and variant class action rule rates, but with a slightly smaller percentage of replica rules states amending and a slightly larger percentage of 'variant rules states amending. Indeed, Figure 5 shows a pattern similar to the one in Figure 4: while only $25 \%$ of replica rules states allowed expanded opportunities for class interlocutory appeals prior to Rule 23(f), 59\% of the states in that category did so by 2009 . For variant rules states, 53\% already provided such appeals in 1998, and the amending states in that category raised the total today to $65 \%$. By 2009 , then, variant rules states proved slightly more likely to provide expanded appellate opportunities than replica rules states, but post-Rule 23(f) replica rules states amended at a higher rate than variant states.

As in the case of replica Rule 23 states, however, these findings likely overstate the degree of state replication of Rule 23(f). Again, if replication is defined as following Rule 23(f)'s discretionary class appeals approach, only seven of the eleven replica rules states truly replicated Rule 23(f), while four of the eleven provided automatic appeals to class litigants. The result is that if one looks at actual replica behavior, $29 \%$ of the replica Rule 23 states amended in conformity with 
Rule 23(f), while another $14 \%$ of the replica Rule 23 states amended only in the overall direction of the federal change (from limited to expanded class appeals).

3. Replica States by Rate of Federal Rule Amendment Adoptions: The Oakley Scale

In 2003, Professor Oakley took a "fresh look" at the replication status of replica federal rules states, ${ }^{182}$ examining the rates at which those states "continued to conform to the Federal Rules" by amending their state procedures to track major federal rule amendments of the 1980s and 1990s. ${ }^{183}$ To conduct this research, Professor Oakley chose twelve amendments to the Federal Rules he characterized as significant enough to indicate "pro tanto textual disuniformity between state and federal procedure if not adopted by a state that otherwise conforms to the federal rules." 184

The states in the Oakley study varied dramatically in their adoption rate of the twelve amendments he identified. The overall adoption rate among all replica rules states was $42 \%$, with almost one third of the states adopting either $42 \%$ or $50 \%$ of the amendments. ${ }^{185}$ With its $92 \%$ adoption rate, Utah topped the list of replica states, demonstrating the highest degree of conformity with the selected federal rule amendments. ${ }^{186}$ South Dakota, at the other extreme, adopted none of the amendments Oakley examined. ${ }^{187}$

\footnotetext{
182. Professor Oakley limited this survey to states identified in his 1986 work as "substantially conforming to the federal model of civil procedure," states I have herein referred to as "replica rules states.” Oakley, supra note 7, at 354.

183. Id. at 360-61 (detailing the specific amendments and criteria used by Professor Oakley).

184. Id. at 359. Professor Oakley also examined a thirteenth amendment, the 2000 federal amendment to Rule 26, but because of that amendment's "recent enactment, [he] considered it apart from the other sample amendments as an index of state willingness to conform to the federal model." Id. at 360. As that amendment also occurred two years after Rule 23(f), I do not include adoptions (or non-adoptions) of it in my analysis, and limit my data to the twelve 1980-1993 amendments that are the central focus of Oakley's research.

185. See id. at 387 tbl. 3.

186. See id. at 371-72, 387 tbl. 3.

187. See id. at 370-71, 387 tbl. 3.
} 
Figure 6: States With Limited Interlocutory Appeals That Amended, By Percentage of FRCP Adoptions

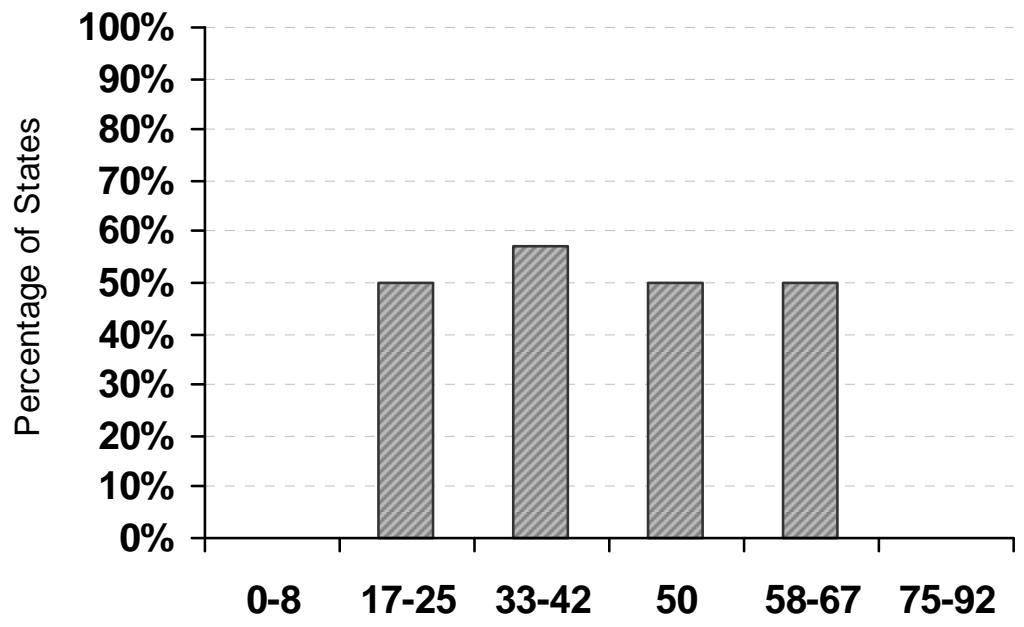

Percentage of 1980-1993 FRCP Amendments Adopted

The Replica Theory would posit that states demonstrating a relatively high rate of federal amendment adoption in the Oakley study also would be relatively more likely than states at the lower end of that scale to amend their procedural rules to adopt Rule 23(f). Figure 6 shows the percentage of states that amended to expand appellate review in class actions in each of six ranges on the Oakley scale. ${ }^{188}$ While there were no amendments among states in the lowest and highest bands, states in the four middle bands ${ }^{189}$ all hover around a 50\% rate of amendments expanding class action appeals. ${ }^{190}$

The reason no states at the lowest end of the Oakley scale ${ }^{191}$ likely adopted Rule 23(f) is presumably explained by Figure 7: they each provided expanded appellate access for class litigants well before Rule

188. Because of the uneven distribution of states, the bands examined do not include equal numbers of states. There are three states in both the $0 \%$ to $8 \%$ and the $75 \%$ to $92 \%$ categories, five states in the $58 \%$ to $67 \%$ category, and seven states in the $17 \%$ to $25 \%$, $33 \%$ to $42 \%$, and $50 \%$ categories.

189. These four bands include states with adoption rates of Oakley's selected federal amendments ranging from $17 \%$ to $67 \%$.

190. The numbers in each band are so low that the $57 \%$ rate in the band of states adopting 33 $42 \%$ of Oakley's amendments is likely statistically indistinguishable from $50 \%$.

191. These states adopted between $0 \%$ and $8 \%$ of the selected Oakley amendments. 
23(f). The general lack of conformity with other federal rule amendments among states at the lowest end of the Oakley scale may make sense of the pre-existing availability of appellate review in those states: their treatment of class appeals pre-Rule 23(f) reflects the same disuniformity with federal procedural practices as their disinclination to replicate other federal rule amendments from 1980-2000.

Figure 7: Availability of Interlocutory Appeals, By FRCP Amendment Adoption Rate

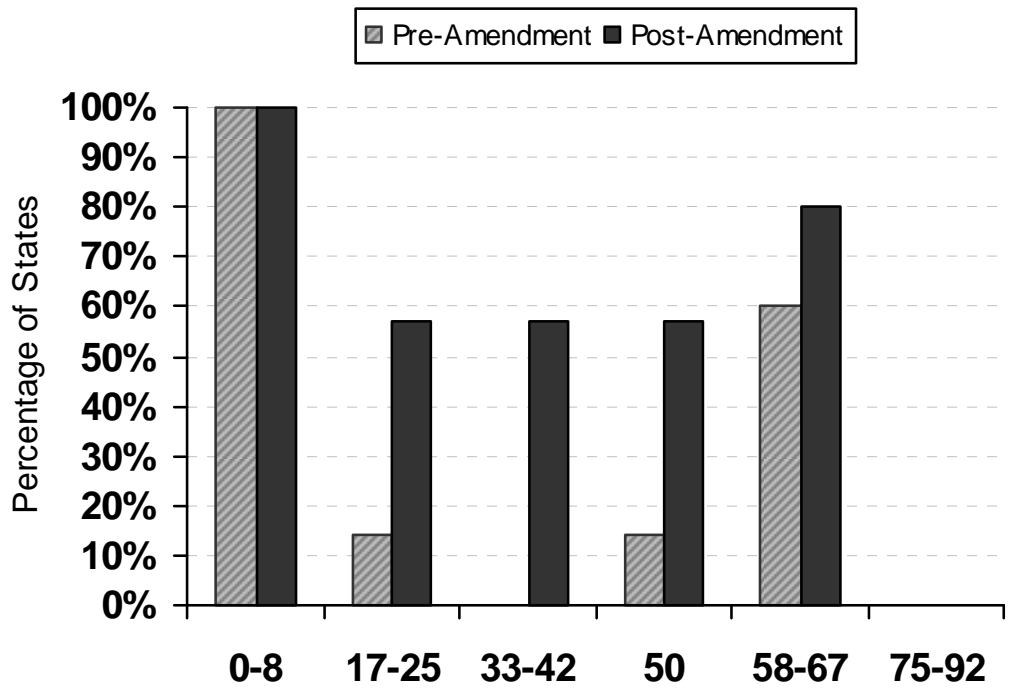

Percentage of 1980-1993 FRCP Amendments Adopted

As Figure 7 reveals, however, none of the states at the highest end of the Oakley scale ${ }^{192}$ provided similar appellate opportunities pre-Rule 23(f). Their pre-Rule 23(f) limitation on class appeals certainly aligns closely with the pre-1998 federal approach, but the failure of any of those states to amend post-Rule 23(f) is far less easy to explain given their high degree of replication with respect to other federal rule amendments. ${ }^{193}$ On the other hand, $80 \%$ of states in the second highest band $^{194}$ today offer expanded interlocutory class appeals, a high rate that might have been predicted for such states previously demonstrating a

192. States in this highest band adopted between $75 \%$ and $92 \%$ of the Oakley amendments.

193. At least part of the answer to this riddle may lie simply in the exceedingly small number of states at the highest end of the Oakley scale.

194. States in this band adopted $58 \%$ to $67 \%$ of the Oakley amendments. 
high degree of federal rule amendment replication. But Figure 7 shows that those states also registered a $60 \%$ rate of providing such expanded appeals even before Rule 23(f), a degree of pre-Rule 23(f) nonconformity with the federal appeals policy that rivals that of the states at the lowest (and most non-conforming) end of the Oakley scale.

The treatment of class action appeals among states in the second, third, and fourth bands ${ }^{195}$ appears to fit most closely with Replica Theory expectations, with low rates (between $0 \%$ and 14\%) of pre-Rule 23(f) expanded class appeals and post-Rule 23(f) rates that fall just under 60\%. Nonetheless, the overall data presented in Figures 6 and 7 supply little support for a correlation between replica states' overall rate of continued replication and a state's likelihood of replicating the approach taken in Federal Rule 23(f). States that we would have expected to adopt Rule 23(f), based on their track record of replicating other federal rule amendments at the highest rates, did not do so. And states in the next highest band already provided expanded class appeals at a rate inconsistent with a desire to replicate the federal class appellate approach, although perhaps the post-Rule 23(f) amending states in that band were motivated to amend on that basis.

\section{Adoption of Uniform Laws as Measure of Replica Theory}

Absent a comprehensive survey of state procedural laws examining the extent to which states adopt rules seeking to replicate or achieve uniformity with those of other states rather than the federal rules, it is difficult to readily test a state-based replica effect. Such an effect surely must exist to some extent, as states regularly coordinate through a number of organizations to promulgate uniform guidelines and laws. ${ }^{196}$ North Dakota's class action rule, for example, is based on the National Conference of Commissioners on Uniform State Laws' ("NCCUSL”) Uniform Class Actions Act/Model Class Action Rule rather than on

195. States in these bands adopted between $17 \%$ and $50 \%$ of the Oakley amendments.

196. One recent example of states' efforts to engage in parallel, coordinated rulemaking can be seen in the state court guidelines on electronic discovery released by a joint working group of the Conference of Chief Judges and National Center for State Courts in 2006, the same year the Supreme Court approved extensive amendments to the Federal Rules on the same subject. See Conference of Chief Justices \& National Center for State Courts, Working Group on Electronic Discovery, Guidelines for State Trial Courts Regarding Discovery of Electronically-Stored Information (2006), http://www.ncsonline.org/images/EDiscCCJGuidelinesFinal.pdf. A court in one state categorized by Oakley as a federal rules replica state, for example, recently relied in part on these guidelines to determine a "reasonable approach" to the e-discovery dispute at issue. See Beard Research, Inc. v. Kates, 981 A.2d 1175, 1187 n. 66 (Del. Ch. 2009); see also Oakley, supra note 7, at 379-81. 
Federal Rule 23, ${ }^{197}$ even though its procedural rules in other significant respects qualified it as a "replica" federal rules state in the Oakley surveys. ${ }^{198}$ Indeed, NCCUSL actively seeks to promote the goal of uniform state laws. ${ }^{199}$

In 1996, Professors Larry Ribstein and Bruce Kobayashi examined the rate at which states adopted 103 uniform laws promulgated by NCCUSL. ${ }^{200}$ While the Uniform Class Action Act is one of the uniform laws in Ribstein and Kobayashi's study, it is one of the rare procedural proposals offered by the NCCUSL. The uniform laws surveyed run the substantive gamut from laws governing limited partnerships to transboundary pollution, from antitrust to child custody, from probate to extradition and rendition. ${ }^{201}$ While states' relative adoption rates of substantive uniform laws, therefore, may be far from a perfect indicator of a state's likelihood of adopting procedural rules based on a desire to replicate those of other states, it may nonetheless shed some light on the relative inclination among states to follow uniform guidelines emanating from state-based rather than federal sources. ${ }^{202}$

Using the Ribstein and Kobayashi data, ${ }^{203}$ I examined the possible correlation between a state's uniform law adoption ranking and its likelihood of amending its rules to expand interlocutory appellate access

197. See Rowe, supra note 77 , at 150.

198. See Oakley, supra note 7, at 368-69; Oakley \& Coon, supra note 156, at 1412.

199. See Larry E. Ribstein \& Bruce H. Kobayashi, An Economic Analysis of Uniform State Laws, 25 J. LEGAL STUD. 131, 135 (1996) (explaining that "the history suggests that both the NCCUSL and state legislators have sought to achieve the maximum possible level of uniformity of state laws”).

200. Id. Ribstein and Kobayashi's economic analysis identified the risk of inefficient and "inappropriate uniformity" that may occur when states widely adopt "inappropriate uniform laws" promulgated by the NCCUSL. Id. at 135 .

201. See id. app. at 188-93 (Table A1).

202. Ribstein and Kobayashi found that whether a state's legislature was full-time or part-time proved to be a statistically significant indicator of a state's likelihood of adopting uniform laws. See id. at 169-71. Their findings supported the hypothesis that states are "more likely to adopt uniform laws when the legislature serves only part-time. In this situation, the legislature lacks the time and expertise to innovate." Id. Given that half of the states post-Rule 23(f) amended their class appellate rules by judicial rather than legislative rulemaking, examination of a possible correlation between Ribstein and Kobayashi's part-time and full-time legislature hypothesis and a state's likelihood of expanding appellate rules for class litigants is beyond the scope of this Article. An analogous hypothesis, however, may help to explain the high concentration of federal rule replica states among those states with the lowest populations, as they also may have fewer resources to devote to the development of state-specific procedural rules. See Oakley \& Coon, supra note 156, at 1426 ("States with large populations seemed to be less likely to have systematically modeled their civil procedures on the Federal Rules than less populous states.”). But see Ribstein \& Kobayashi, supra note 199, at 174 (finding population not to be a statistically significant predictor of uniform law adoption).

203. See Ribstein \& Kobayashi, supra note 199, at 170-71 (Table 4: Average Change in Probabilities from State Fixed Effects — by Type of Legislature and Rank: Probit Analysis). 
for class litigants. The Replica Theory here would suggest that states on the high end of the Ribstein and Kobayashi rankings (demonstrating a high inclination to adopt rules seeking interstate uniformity) would be most likely to track or borrow what they perceived to be an increasingly "uniform" class action procedure in other states. On the other hand, the Replica Theory suggests that states on the low end of the Ribstein and Kobayashi rankings would be less likely to amend their rules to seek some degree of conformity or uniformity with sister states, as those states previously demonstrated a significant disinclination to adopt uniform state laws promulgated by the NCCUSL.

Figure 8: States With Limited Interlocutory Appeals That Amended, By Uniform Law Adoptions

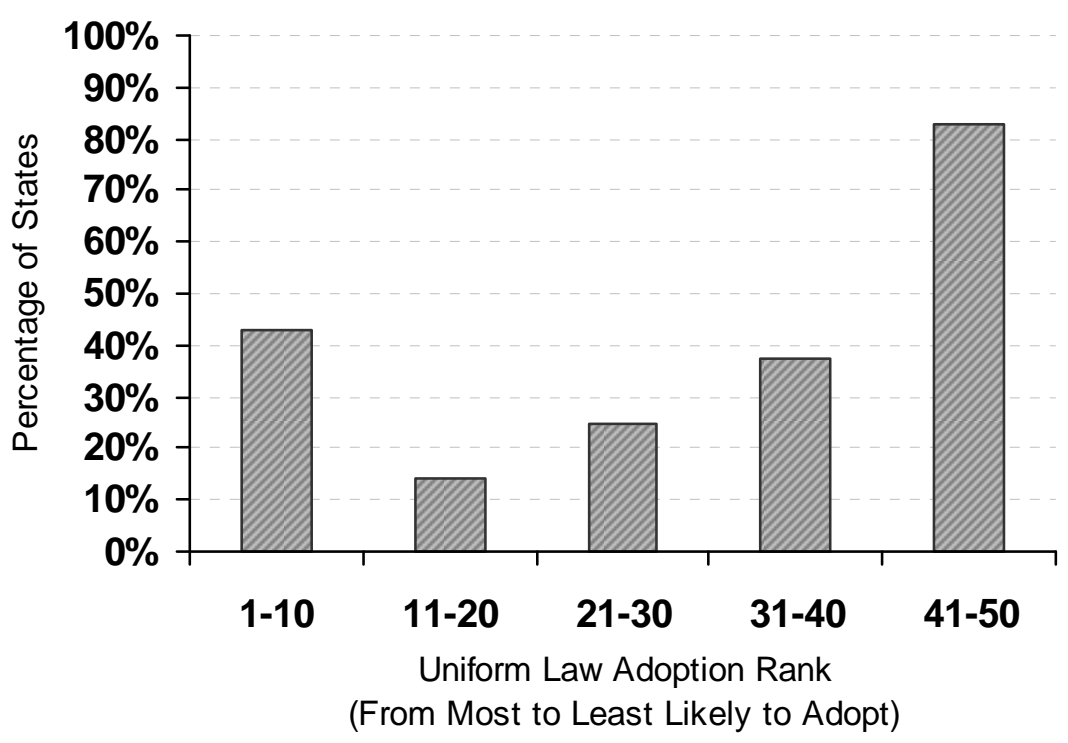

Figure 8 shows the percentage of amending states in each quintile of the Ribstein and Kobayashi rankings. As one can see in even a cursory glance at the data in Figure 8, the predicted effects are not borne out. Of the states with the lowest uniform law adoption rate, in the bottom quintile of states (ranked 41 to 50), 83\% adopted amendments expanding interlocutory appeals for class certification orders. By comparison, only $43 \%$ of states in the highest quintile (ranked 1 to 10 ) similarly acted to expand class action appellate rules. The percentage of states adopting class action appeal amendments rises steadily upwards in the middle three bands, with the third quintile (ranked 21 to 30) amending at a 
higher rate than the second (ranked 11 to 20), and the states in the fourth quintile (ranked 31 to 40 ) amending at a still higher rate than the third. ${ }^{204}$

Figure 9: Availability of Interlocutory Appeals, By Uniform Law Adoptions

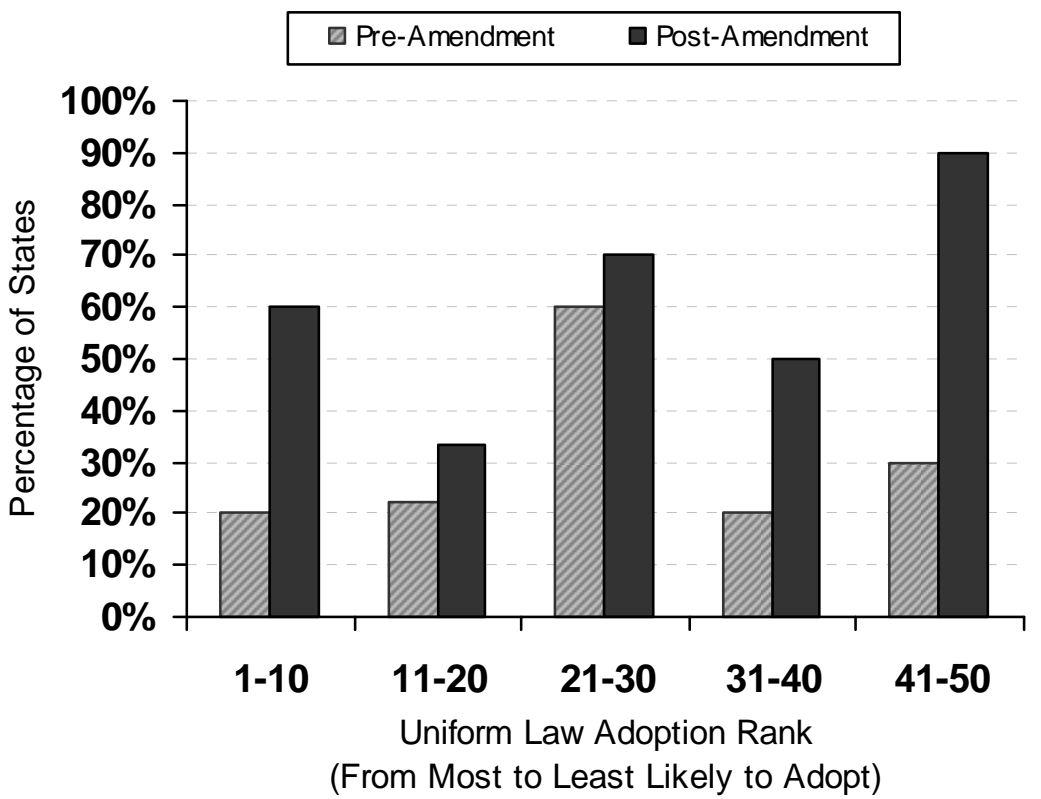

Figure 9 shows the same Ribstein and Kobayashi state adoption rankings, here comparing the percentage of states in each quintile that already had expanded class action appeals rules pre-Rule 23(f) and the percentage that provide such appellate opportunities today. The jump among states in the lowest quintile (ranked 41 to 50 in uniform law adoptions) still appears to be evident, with $30 \%$ of states in that group providing expanded appeals pre-amendment and fully $90 \%$ postamendment. The first (ranked 1 to 10) and fourth (ranked 31 to 40) quintiles look much the same, each with $20 \%$ pre-amendment and $50 \%$ to $60 \%$ post-amendment, while the second quintile reveals the least reaction (22\% of states pre-amendment and 33\% post-amendment provided expanded class interlocutory appeals). The third quintile, on the other hand, reveals a notable $60 \%$ of states pre-amendment and a final $70 \%$ tally of states post-amendment providing expanded appeals.

204. Virginia and Mississippi, excluded from my analysis in Figure 7, ranked 18th and 48th (respectively) in the study. 
In summary, it is hard to discern any support from these data for a replica effect based on the class action appellate practices of sister states. States one might predict would be most interested in following an increasingly "uniform" rule followed in other states did move from $20 \%$ permitting class action appeals pre-Rule 23(f) to $60 \%$ today, but the next highest quintile amended at a far lower rate. Those in the middle of the pack in the third quintile were notably more likely to have expanded class appeals pre-amendment, for reasons not easily explained by their relative inclination to adopt uniform laws. And the states most seemingly independent and unlikely to adopt uniform law proposals acted the most dramatically to amend their class action appellate rules in the wake of Rule 23(f), the direct opposite of what the replica theory would have predicted.

\section{B. The Interest Group Theory}

Class actions have long been the source of heated controversy, in litigation and legislative conflicts so fierce they could be described in warlike terms. ${ }^{205}$ While the rhetoric surrounding the class action debates of the last few decades has often reached a fever pitch, it nonetheless cannot be denied that the rules governing when and how groups of plaintiffs may bring suit on a representative basis implicate social, political, and substantive policies like few other procedural rules. The class certification determination itself is situated at the very heart of this debate: denying class status results in exponentially smaller individual stakes (or possibly abandonment of the suit altogether), while certifying a class may lead a defendant to settle even class claims it believes lack merit due to the threat of an enormous class damages award. ${ }^{206}$

As a result of the tremendous potential consequences of that threshold decision, therefore, interest groups have attempted to influence the procedural rules relating to class action standards ever since the massive revamping of Federal Rule 23 was completed in $1966 .^{207}$ One need not look hard to find that interest groups seeking to limit liability or

205. See, e.g., John C. Coffee, Jr., Class Wars: The Dilemma of the Mass Tort Class Action, 95 Colum. L. ReV. 1343 (1995); Arthur R. Miller, Of Frankenstein Monsters and Shining Knights: Myth, Reality, and the "Class Action Problem", 92 HARV. L. Rev. 664, 664 (1979) ("For more than a decade segments of the bench and bar have been waging a holy war over Rule 23 of the Federal Rules of Civil Procedure.”).

206. See supra notes 22-23 and accompanying text.

207. See generally HENSLER ET AL., supra note 7, 15-22 (describing early controversy and backlash against the Federal Rule 23 amendments of 1966, particularly related to Rule 23(b)(3) damages class actions). 
restrict access to courts through tort reform are similarly invested in retracting the availability of class actions through rulemaking or legislative processes. ${ }^{208}$ The American Tort Reform Association (ATRA) developed its rankings of state "Judicial Hellholes" based in part on its desire to target plaintiff-friendly class action venues. ${ }^{209}$ The Chamber of Commerce includes class action reform on its list of 101 ways to improve state courts, ${ }^{210}$ and regularly takes account of class actions in its yearly surveys ranking state liability systems. ${ }^{211}$ On the other side, the plaintiffs' bar has inveighed against legislative and rulemaking efforts to restrict class actions. One sees this not only in the plaintiff-oriented critics of Rule 23(f) itself, ${ }^{212}$ but also in the array of consumer and public interest groups that ardently opposed the passage of CAFA. $^{213}$

208. See, e.g., Richard L. Marcus, They Can't Do That, Can They? Tort Reform Via Rule 23, 80 CORNELL L. REV. 858, 859 (1995) (colorfully explaining that "the class action has landed like a 600pound gorilla in the arena of tort reform"); Patricia W. Hatamyar, The Effect of "Tort Reform" on Tort Case Filings, 43 VAL. U. L. REV. 559, 582 (2009) (observing that "[t]he 'tort reform' movement has frequently targeted class actions”); Purcell, supra note 56, at 1904 n.330 (arguing that "[t]he hand of the "tort reform" movement was visible throughout CAFA's course through Congress”).

209. See Am. Tort Reform Ass'N, supra note 115. But see Public Citizen's Congress WATch, Class ACtion "Judicial HellHOles": EMPIRICAl EVIDENCE IS LACKING 3 (2005) (critiquing the "paucity of evidence" to support ATRA's claims about judicial hellhole jurisdictions, noting that ATRA identified only nine jurisdictions out of the 3,141 U.S. court systems).

210. See U.S. CHAMBER InSTITUTE FOR LEGAL REFORM, supra note 48, at 20; see also Victor E. Schwartz, Mark A. Behrens, \& Leah Lorber, Tort Reform Past, Present and Future: Solving Old Problems and Dealing with "New Style” Litigation, 27 WM. MitCHELl L. REV. 237, 268 (2000) (urging tort reformers to think beyond "traditional" tort reform efforts, and identifying class actions as one of the most important tort reform goals of the future).

211. See, e.g., U.S. ChAMBER INSTITUTE fOR LEgAL Reform, 2008 U.S. Chamber OF COMmerCe State Liability Systems RANKING Study (Table 11: Treatment of Class Action Suits and Mass Consolidation Suits) http://www.instituteforlegalreform.com/index.php?option=com _ilr_harris_poll\&year=2008\&Itemid=18/. The Chamber's annual state survey methodology, based on interviews with in-house corporate counsel, has been the subject of formidable criticism. See, e.g., Theodore Eisenberg, U.S. Chamber of Commerce Liability Survey: Inaccurate, Unfair, and Bad for Business, 6 J. EMPIRICAL LEGAL STUD. 969, 970 (2009) (concluding that "[t]he survey lacks elementary social scientific objectivity and incorrectly characterizes state law”); Stephen J. Choi, Mitu Gulati, \& Eric A. Posner, Judicial Evaluations and Information Forcing: Ranking State High Courts and Their Judges, 58 DuKE L.J. 1313, 1316-17 (2009) (observing that the Chamber's rankings "reflect judgments of various individuals who do not necessarily have good judgment, express their views sincerely, or take account of all relevant considerations”); PUBLIC CITIZEN’s CONGRESS WATCH, supra note 209, at 4 (asserting that the survey's results "should be approached with great caution as the respondents in the survey group have a clear bias”).

212. See supra notes 34-36 and accompanying text.

213. See, e.g., PUBLIC CitIZEN's CONGRESS WATCH, supra note 209, at 2 (arguing that no empirical support justified "rewriting class action rules across the country that will dramatically reduce the legal rights of consumers and workers”); S. Rep. No. 109-14, at 82-83 n.4 (2005) (listing letters to Senate Judiciary Committee members in opposition to similar class action measures from, inter alia, National Association of Consumer Advocates, National Consumer Law Center, Public Citizen, and U.S. Public Interest Research Group). 
This section explores the extent to which the influence of interest groups may help to explain why some states acted post-Rule 23(f) to amend their class action rules to increase appellate opportunities, and others did not. ${ }^{214}$ As neutral as federal rulemakers may have intended to be in promulgating Rule 23(f), and as non-partisan as the rationales for it may have been, ${ }^{215}$ the substantive effect of the amendment appears to favor defendants opposed to class certification. ${ }^{216}$ Certainly at the time, as the Advisory Committee well knew, federal appellate courts (including the Supreme Court) that did exercise appellate review usually applied more rigorous certification standards than district courts, and more often reversed than upheld controversial class certification decisions. ${ }^{217}$ And it cannot be denied that supporters and opponents of Rule 23(f) divided largely along interest group lines: defendant-oriented interest groups championed it, while plaintiff-oriented interest groups testified against it. ${ }^{218}$ The Interest Group Theory therefore suggests that a similar line-up might have engaged in parallel efforts for and against the expansion of appellate access for class litigants in the states.

To test the Interest Group Theory, this section examines several possible measures of interest group incentives and opportunities to influence state rulemaking processes. I begin with perhaps the most obvious evidence of interest group influence, the relative amenability of each state toward various tort reforms. The Interest Group Theory would hypothesize that states that had proved to be highly receptive to tort reforms would also be more likely to engage in class action reform that provided an opportunity for tighter appellate scrutiny of class certification standards. ${ }^{219}$ Alternatively, I examine whether states

214. Cf. Carrington, supra note 38, at 163 (observing that "legislative solutions to the problems of courts are prone to favor those factional interests that are best organized, thus reflecting the procedural preferences of those whom Marc Galanter has aptly described as 'repeat players,' [which] adds to the advantage already held by such litigants”).

215. See supra note 30 and accompanying text.

216. See, e.g., George L. Priest, Procedural Versus Substantive Controls of Mass Tort Class Actions, 26 J. LEGAL STUD. 521, 557 (1997) (arguing that the Advisory Committee's endorsement of Rule 23(f) reflected its "necessarily substantive" desire to "reduc[e] the circumstances in which classes will be certified”); see also supra notes 43-46 and accompanying text.

217. See, e.g., Amchem Prods., Inc. v. Windsor, 521 U.S. 591, 597 (1997); In re Am. Med. Sys., Inc., 75 F.3d 1069, 1090 (6th Cir. 1996); In re Rhone-Poulenc Rorer, Inc., 51 F.3d 1293, 1304 (7th Cir. 1995); In re General Motors Corp. Pick-up Truck Fuel Tank Prods. Liab. Litig., 55 F.3d 768, 779 (3rd Cir. 1995); see also Priest, supra note 216, at 558 (citing Rhone-Poulenc, General Motors, American Medical Systems, and the Third Circuit's decision in Amchem as support for the contention that Rule 23(f) "will also enhance appellate authority to determine . . . whether the underlying claim of the purported class lacks substantive merit”).

218. See supra notes 33-36 and accompanying text.

219. See Priest, supra note 216, at 540 ("A purely procedural approach to class action reform, however, necessarily ignores the relationship between the class action and the substantive ends of 
perceived to be hotbeds of class action activity prior to Rule 23(f) were more likely to amend their class appellate rules, a finding that also would be consistent with the Interest Group Theory. Next, I explore the possible correlation between the number of Fortune 500 company headquarters in a state and its likelihood of adopting a state equivalent of Rule 23(f), hypothesizing that states with large numbers of such corporate headquarters would be more likely to experience defendant interest group pressure to adopt state class action appellate rules providing expanded opportunities to limit class actions. Finally, given that class action appellate rules may be promulgated by a state's supreme court, I consider whether a state's method of selecting the members of its supreme court (by appointment or election) reveals potential interest group influence.

\section{State Tort Reform Adoption}

To examine the correlation, if any, between a state's relative amenability to tort reform ${ }^{220}$ generally and its decision to amend its procedural rules to provide greater appellate access for class litigants, I looked to state tort reform data collected by Professor Ronen Avraham. The recently released third version of Professor Avraham's Database of State Tort Law Reforms (DSTLR) represents the "most complete and comprehensive legal dataset" on tort reforms, including all fifty states and the District of Columbia. ${ }^{221}$ The DSTLR details decades of state activity regarding "the most prevalent tort reforms in the United States,"222 including laws related to joint and several liability, the collateral source rule, split recovery, periodic payments, punitive

tort law.").

220. I use the commonly invoked term "tort reform" to refer to laws seeking to limit liability and/or litigant access to courts, and do not intend to suggest that such so-called "reforms" actually reflect positive substantive advancements. See, e.g., F. Patrick Hubbard, The Nature and Impact of the “Tort Reform” Movement, 35 HofSTRA L. REV. 437, 457 (2006).

221. Ronen Avraham, Database of State Tort Law Reforms (3rd), 2 (Apr. 2010), http:// sssn.com/abstract $=902711$.

222. Id. One limitation on using this database as a proxy for state interest in tort reform generally is that it focuses on reforms related to medical malpractice. As Professor Avraham acknowledges in his introduction, while the DSTLR includes "general reforms and product liability related reforms[,] . . . the medical liability reforms are in general more complete and reliable.” Id. at 9. While the DSTLR (3rd) remains by far the best empirical source for measuring state tort reform activity in 1998, the effective date of Federal Rule 23(f), it proved less helpful in correlating class action appellate rule changes with contemporaneous tort reform activity. In a state like Colorado, for example, the DSTLR (3rd) reports no tort reform adoptions in the years immediately surrounding the date of its class action appellate rule change, despite documented tort reform measures enacted during that same 2003 legislative session. This is not a failure of the DSTLR3rd data, but simply reveals the broad range of legislative activity that may be effectively viewed as tort reforms. 
damages evidence, contingency fees, patient compensation funds, and caps on non-economic damages, punitive damages, and total damages.

The Interest Group Theory suggests states that have already adopted rules limiting tort liability would also be likely to adopt rules that expand appellate access for class litigants, a particular policy goal of defendants. Therefore, one might expect to find a higher incidence of class appellate rule amendments among states that had already adopted the highest numbers of tort reforms. Conversely, states without significant tort reform adoptions might represent plaintiff-friendly class action states more likely to be the targets of defendant-oriented interest groups seeking to achieve tort reform goals via class action procedural reforms (that might not be as controversial or high-profile as other tort reform efforts). ${ }^{223}$ On this view, one might expect to see a high percentage of class appellate rule changes among states that had previously adopted few tort reforms.

Figure 10: States With Limited Interlocutory Appeals That Amended, By Tort Reform Adoption

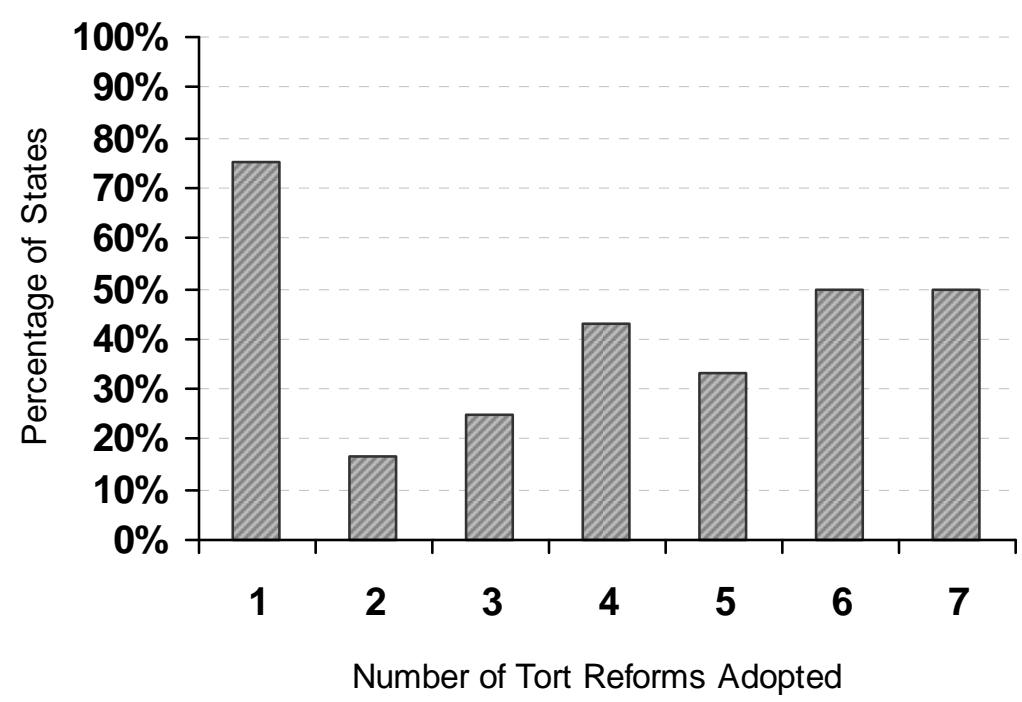

To test these hypotheses, I examined the status of state tort reform adoptions as of 1998, the year Rule 23(f) became effective. No state had adopted all ten reforms included in the DSTLR, and no state had

223. See supra note 136 and accompanying text. 
declined to adopt any of the reforms. On a scale of one to seven DSTLR tort reform adoptions, then, Figure 10 indicates the percentage of states that expanded appellate access for class litigants among those that did not already provide such expanded opportunities. The highest percentage of amending states, $75 \%$, can be found among states adopting only one tort reform as of that year, although there were only five states in that category. The next group of states, which had adopted only two reforms, is consistent with what the Interest Theory would have predicted, the lowest percentage of states (17\%) that subsequently amended class rules to expand appellate opportunities. The percentage moves up to $25 \%$ for states that had adopted three tort reforms, climbs to $43 \%$ for states that adopted four reforms, and then falls back down to $33 \%$ of states that adopted five reforms. At the top end of the scale, where the Interest Theory would have hypothesized a high level of class action appellate reform activity, $50 \%$ of states that had adopted either six or seven tort reforms subsequently amended their class appeals rules. That level exceeds that of any group of states other than those at the lowest end of the scale, as well as the overall average of all amending states (40\%), but not to a particularly dramatic degree.

Figure 11: Availability of Interlocutory Appeals, By State Tort Reform Adoptions

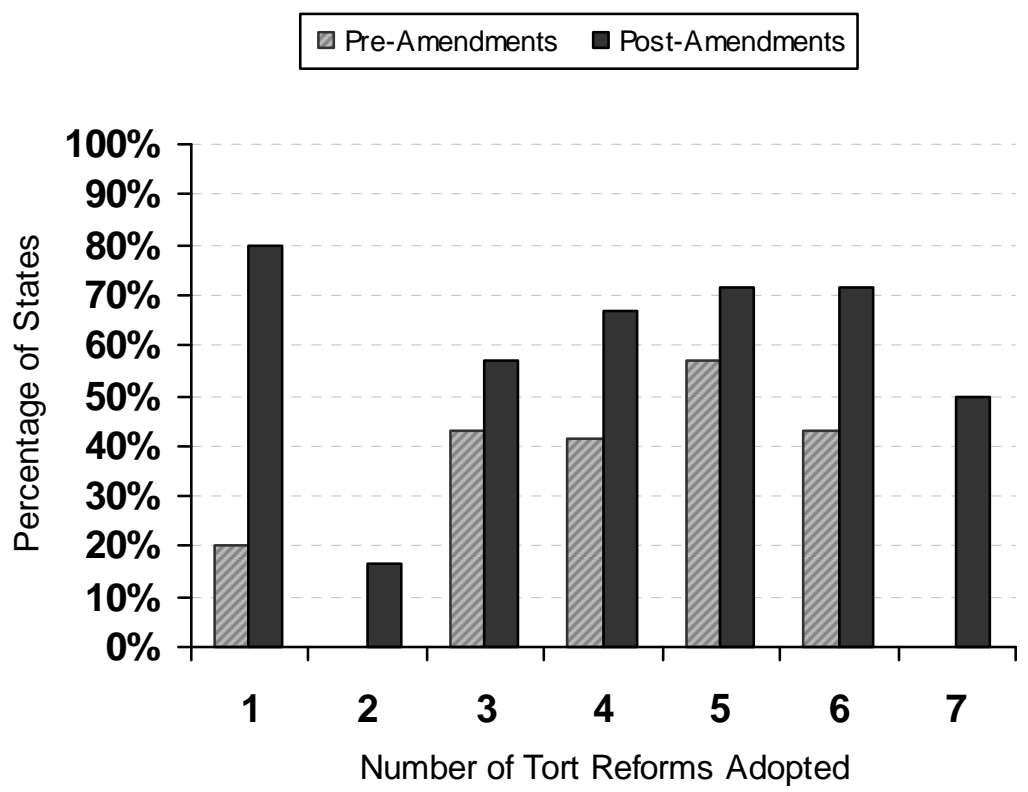

Figure 11 looks at the pre-Rule 23(f) and post-Rule 23(f) percentage of states in each category that provided expanded class appeals. The 
biggest increases in the percentages of states pre- and post-Rule 23(f) occurred at both extremes of the scale: while only $20 \%$ of the states that had only adopted one of tort reforms measured by Professor Avraham provided expanded appellate access pre-Rule 23(f), that number today has jumped to $80 \%$. At the top end of the scale, none of the states that had already adopted seven tort reforms previously allowed expanded class appeals, but today $50 \%$ do so. Not only are the numbers at both ends quite small, however, but the percentage of states allowing expanded class appeals at the top end is actually smaller than the overall percentage of states today (61\%), so it is difficult to count even those apparently notable increases as reliable indicators of an Interest Group effect.

The rest of the Figure 11 underscores the dubious correlation between tort reform adoptions and likelihood of adopting this particular class action reform. States that had adopted two tort reforms went from $0 \%$ to $17 \%$, which would suggest that those states were unlikely to adopt either tort reform generally or expansion of class appeals. But $42 \%$ to $57 \%$ of the twenty-five states in the middle of the scale (which had adopted from three to five tort reforms) already provided expanded class appellate review pre-Rule 23(f), and now $57 \%$ to $72 \%$ do so. In sum, the expected increases in amenability to this class action reform at the top of the tort reform adoption scale cannot be found in this data, and while some Interest Group effects may be happening at the lowest end of the scale we do not have sufficient data to support that hypothesis either. ${ }^{224}$

\section{Class Action "Hot States"}

The next measure of the Interest Group Theory examines the possible correlation between so-called "hot states," those states that were perceived to be hotbeds of class action activity pre-Rule 23(f), and states that expanded class appellate rules post-Rule 23(f). The Interest Group Theory would posit that defendant-oriented interest groups seeking to curtail class actions in such "hot states" might have attempted to exercise influence in those states more than in states not seen to be as willing to certify class actions.

\footnotetext{
224. In future research, I hope to look more closely at the DSTLR (3rd) data and perhaps determine a methodology to capture additional evidence of state tort reform efforts. The intriguing relationship between tort reform and class action reform, which I suspect to be quite significant, nonetheless cannot be supported with regard to the DSTLR (3rd) data standing alone.
} 
While the hew and cry over such plaintiff-friendly state court class action certifications ultimately lead to the passage of CAFA, ${ }^{225}$ little empirical support for the proposition of pervasive rogue activity can readily be found. ${ }^{226}$ Detailed empirical studies documenting the actual number or nature of state court class actions ${ }^{227}$ not only did not exist at the time, ${ }^{228}$ they are still difficult to find for the vast majority of states. ${ }^{229}$

Professor Deborah Hensler and others, however, working with the RAND Institute for Civil Justice (ICJ), did conduct extensive class action research in the late 1990s, examining, inter alia, the level of class action activity in the states. The Hensler et al. study gauged such activity by reviewing multiple databases of both published judicial decisions and press reports of class action activity. ${ }^{230}$ As Hensler et al. acknowledged, this approach is far from perfect: "None of the databases provides a comprehensive report of all class action activity in the United States, and each reflects the preferences of its creators-reporters who choose to report only certain news, judicial opinion archivists who report only some decisions."231 But this research nonetheless remains the most accurate available measure of state class action activity in the mid-1990s and certainly helps at least "paint a broad-brush picture of the class action landscape."232

225. See supra notes 54-56 and accompanying text.

226. See Thomas E. Willging \& Shannon R. Wheatman, Attorney Choice of Forum in Class Action Litigation: What Difference Does it Make?, 81 NotRE DAME L. REV. 591, 599 (2006) ("Our data, however, lend little support to the view that state and federal courts differ greatly in how they resolve class actions. For example, state and federal courts were equally unlikely to certify cases filed as class actions."); see also supra notes 55-56 and accompanying text.

227. Cf., David A. Hoffman et al., Docketology, District Courts, and Doctrine, 85 WASH. U. L.R. 681, 684-85 (2007) (describing the benefits and accuracy of an "intensive study of trial court dockets," which helps better "illuminate what the law's rights and duties actually mean in practice").

228. See HENSLER ET AL., supra note 7, at 5.

229. See Hoffman et al., supra note 227, at 729 (acknowledging that state courts utilize electronic docketing far less often than federal courts, and that court dockets before 2003 remain largely unavailable today for either federal or state courts); see also supra note 47 and accompanying text (discussing lack of data for state court class actions). Since 2002, the Chamber of Commerce has conducted annual surveys of corporate counsel regarding perceptions of state court class actions, see supra note 211, but the accuracy of these surveys in depicting actual class action practices in those states has been fiercely challenged. See, e.g., Eisenberg, supra note 211, at 971 (citing "demonstrable errors in the Chamber's treatment of state law, with treatment of ... class actions being especially problematical").

230. See HENSLER ET AL., supra note 7, at 52 (explaining detailed methodology).

231. Id.; see also Hoffman et al., supra note 227, at 727-28 (recommending "great caution in proceeding with quantitative analysis of legal opinions" because "[t]he underrepresentativeness of opinions is obvious and well known").

232. HENSLER ET AL., supra note 7, at 52. It must be noted that Hensler's database included cases filed in both state and federal courts in each state. The categorization of a state as a "hot" class action state, therefore, may have been affected by a relatively high number of federal court class actions in certain states. Professor Hensler and her co-authors found that overall fifty-eight percent 
The Hensler et al. study identified the states with the highest levels of class action activity from 1995-1997, a particularly useful period for examining any correlation between perceived "hot" class action states, as it falls just before the amendment of Federal Rule 23(f) and subsequent state adoption of expanded class action appellate rules. Professor Hensler and her co-authors ranked such "hot" states by two measures: the total number of class action cases and the rate of class actions (the number relative to a state's population). ${ }^{233}$ The study then reported the top five ranking states in each year and on each measure. ${ }^{234}$

The Interest Group Theory would suggest that defendant-oriented interest groups might have sought to influence state class action appellate rules in states perceived as hotbeds of class action activity, on the assumption that increased opportunities for appellate review of class certification orders would help to regulate or deter class actions in those hot states. The plaintiffs' bar, on the other hand, assuming that rules limiting appellate review of class certification orders favored their clients, ${ }^{235}$ might have lobbied to protect their perceived procedural advantage in states that rejected the expansion of appellate access for class action defendants.

To test the Interest Group Theory, I looked at whether the Hensler et al. study's "hot" class action states were more or less likely than all other states (which I refer to as "non-hot" states) to have adopted procedural rules that expanded appellate review for class certification orders following the adoption of Federal Rule 23(f). For the "hot state" categories shown in Figures 12 and 13, I created two separate lists of "hot" states.

The first, "Hot States (Numbers)," includes the nine states that appeared on the Hensler et al. study's top five rankings of states with the highest total number of class action cases, in either 1995-96 or 1996-97, with respect to reported judicial decisions or the general press, excluding

of class actions were filed in state court (as opposed to forty-two percent filed in federal court). Id. at 56 (Figure 3.4). Again, this is far from a perfect measure of state court class action activity, but even federal court class action activity in a state may have influenced a perception among interest groups in that state of the need to secure a higher level of appellate supervision of class actions in state court.

233. Id. at 58 ("We ordered states according to the number and rate (i.e., number per 100,000 population) of class actions we found among reported judicial decisions and covered by the general press . . . ."); see also id. at 62-63 (Figures 3.9 \& 3.10).

234. See id. at 58, 62-63.

235. Cf. PUBLIC CitizEN's CONGRESs WATCH, supra note 209, at 7 (noting that while several states "have amended their rules to allow interlocutory appeals of class certification decisions[,] [s]uch appeals are very harmful to plaintiffs with meritorious claims because it will delay the case [and] halt discovery”). 
multiple listings for any state. ${ }^{236}$ I refer to the remaining forty states that did not appear on those top five rankings as "Non-Hot States (Numbers).” Using the same methodology, I compiled a list of eight states that appeared on the Hensler et al. study's top five rankings of states by total class action rate, which I refer in Figures 12 and 13 as "Hot States (Rate)." The forty-one states that did not appear on any of the top five rankings list of states by rate of class action activity I refer to as "Non-Hot States (Rate)."

Figure 12: States With Limited Interlocutory Appeals That Amended, By "Hot State" Class Action Status

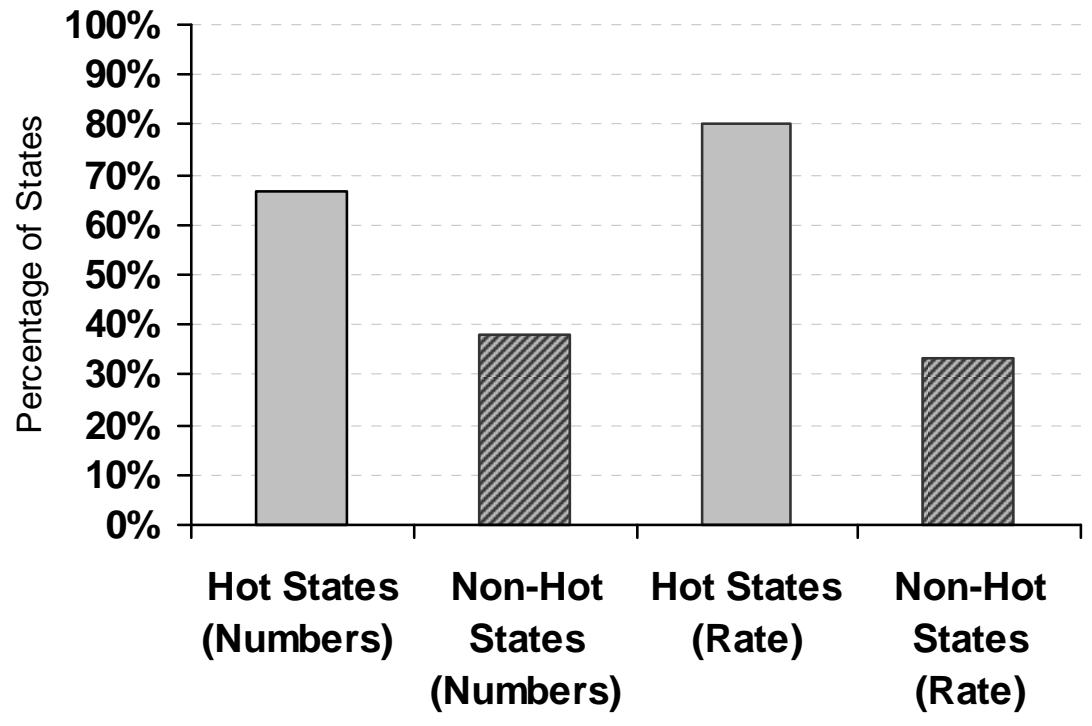

Amending States

As seen in the left half of Figure 12, 67\% of the "Hot States (Numbers)" amended to expand their class appellate rules following the amendment of Rule 23(f). During this same time period, 38\% of the "Non-Hot States (Numbers)" similarly adopted rules that increased class appellate opportunities. More dramatically, as seen in the right half of Figure 12, amendment of class action appellate rules occurred in $80 \%$ of the "Hot States (Rate)," while similar amendment activity occurred in only 33\% of the "Non-Hot States (Rate)." One problem with this measure, however, is the small number of "hot" states, which may inflate the effect of any amendment activity among those states. 
Figure 13: Availability of Interlocutory Appeals, By "Hot" Class Action State Status

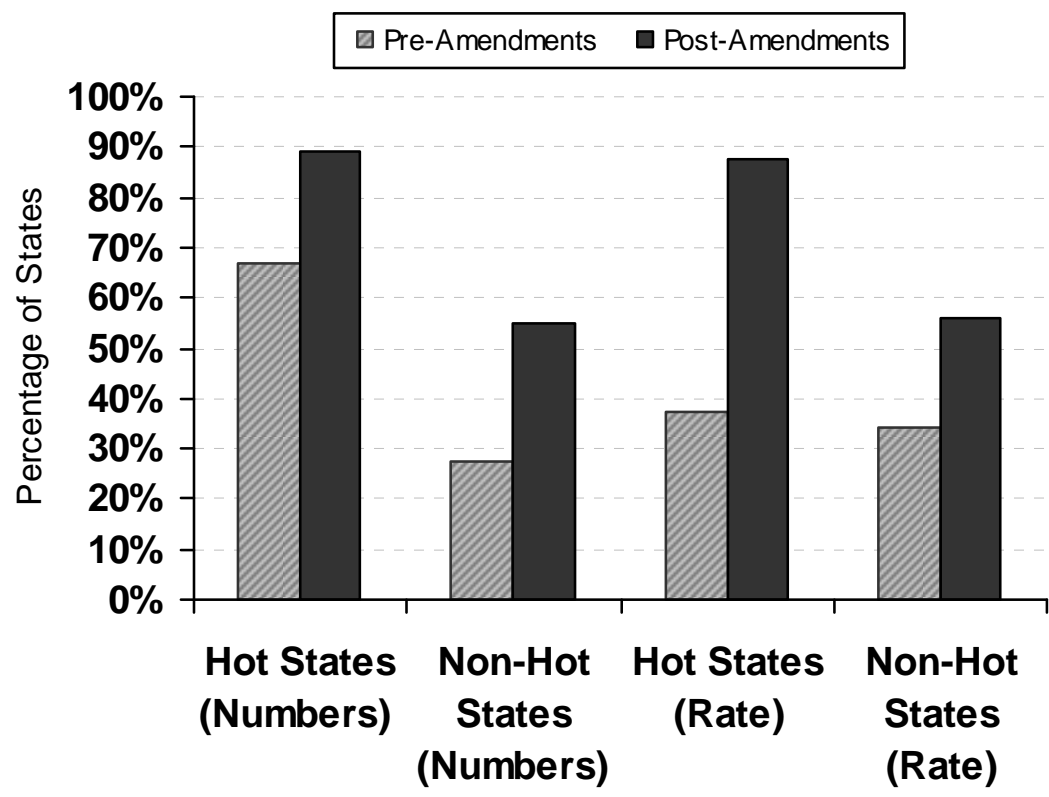

Figure 13 examines the degree to which the apparent differences between hot and non-hot states highlighted in Figure 12 may be mitigated, at least in part, by the pre-Rule 23(f) level of expanded appellate access for class litigants in each category of states. ${ }^{237}$ To the contrary, the left half of Figure 13 shows that a far larger percentage of hot states than non-hot states, defined by total amount of class action activity, already had expanded access to interlocutory appeal of class certification orders: $67 \%$ of hot states had such appeals pre-Rule 23(f) while the same was true in only $27.5 \%$ of non-hot states. Moreover, the resulting percentages for each category (measured by the total number of class action cases) reveal that today $89 \%$ of the Hensler et al. study's hot states provide expanded appellate opportunities for class litigants, as opposed to $55 \%$ of the non-hot states. The right half of Figure 13, showing hot and non-hot states by rate of class action activity, reveals a somewhat similar phenomenon, albeit less marked. Pre-Rule 23(f), only a slightly larger percentage (37.5\%) of hot states than non-hot states

237. In other words, Figure 13 shows whether relatively more "Non-Hot States" than "HotStates," by numbers or rate, already provided expanded class appellate rules before Rule 23(f) such that fewer non-hot states than hot states had incentives to amend. 
(34\%) offered expanded interlocutory class appeals. Post-Rule 23(f), the percentages in each category vary more significantly, with $87.5 \%$ of hot states today providing expanded appellate access for class litigants as compared to $56 \%$ of non-hot states.

In sum, there appears to be a significant correlation between the provision of expansive class interlocutory appeals and states identified in the Hensler et al. study as "hot states," by either total number or rate of class action activity. Hot states seem to have been more likely (in the case of hot states by total number of class actions, much more likely) to have had such preexisting class appeals than non-hot states. And, hot states amended at markedly higher rates than non-hot states, leaving the current percentage of hot states with expanded appellate rights for class litigants just shy of $90 \%$ (by either number or rate measures) while the same is true only in $55-56 \%$ of non-hot states.

\section{Fortune 500 Corporate Headquarters}

States that are home to Fortune 500 corporations also make good candidates for identifying a potential Interest Group Theory effect. First, one would expect states with relatively more large resident corporations to be more likely to respond to lobbying by corporate citizens for state laws favorable to their interests. Second, particularly post-CAFA, instate corporations will often be denied the right to remove class actions brought against them to federal court, so one would expect such entities to be interested in promoting state court procedural rules they perceive to be strategically advantageous. ${ }^{238}$ The Interest Group Theory, then, would posit a correlation between the number of Fortune 500 companies in a state and that state's likelihood of amending its class action rules. Consistent with that theory, one would expect to find a relatively higher percentage of states with high numbers of corporate headquarters providing expanded appellate access.

To study this possible relationship, I used a ranking of Fortune 500 corporate headquarters by state from Fortune Magazine in April of 1998. ${ }^{239}$ I divided the 49 jurisdictions with class actions into approximate quintiles, although there are slightly more states in two of the quintiles because multiple states had the same number of corporate headquarters. ${ }^{240}$

\footnotetext{
238. See supra notes 62-64 and accompanying text.

239. See Fortune 5 Hundred Ranked Within States, ForTUNE, April 27, 1998, at F-32.

240. Specifically, in the quintile of states with six to fifteen Fortune 500 headquarters, there were three states with fifteen headquarters and another three states with six headquarters. Likewise, in the
} 
Figure 14: States With Limited Interlocutory Appeals That Amended, By Fortune $\mathbf{5 0 0}$ Headquarters

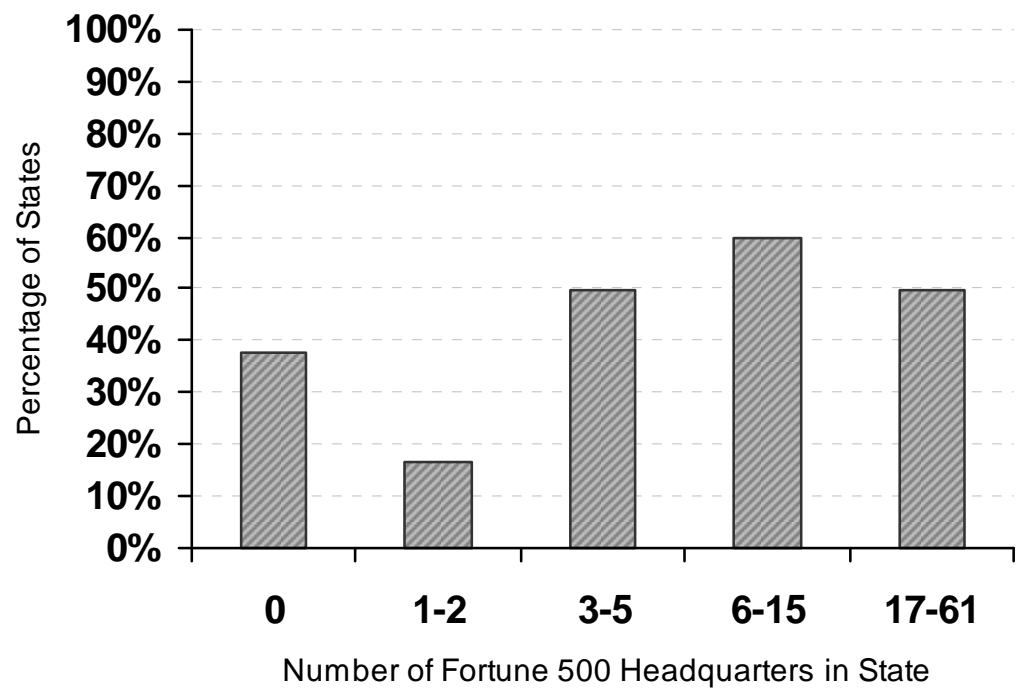

Figure 14 does indeed show higher percentages of states amending class appellate rules in the top three quintiles, with $50 \%$ to $60 \%$ doing so compared to $17 \%$ to $37.5 \%$ in the bottom quintiles. Given that $40 \%$ of states that previously limited appellate access amended overall during this period, the states with three to sixty-one Fortune 500 headquarters were relatively more likely than the overall average and the states with zero to two headquarters to amend. ${ }^{241}$

quintile of states with three to five Fortune 500 corporate headquarters, there were four states with five headquarters and four states with three headquarters. While each of these quintiles contains eleven states, the other three quintiles each contains nine states.

241. While Figure 14 does not show a marked curve increasing from the lowest to the highest numbers of corporate headquarters, a threshold effect may be at play here rather than a linear relationship. In other words, there may be a critical mass of Fortune 500 corporate headquarters located in a state that triggers sufficient interest group influence to effect change. If there is such a threshold effect, then one would not find relatively greater degrees of interest group influence as the number of corporate headquarters increased, but rather (as Figures 16 and 17 appear instead to reveal) an increase at a threshold amount of headquarters and around that same percentage of change across the states with corporate headquarters that exceed that threshold amount, irrespective of the amount of headquarters exceeding the threshold. 
Figure 15: Availability of Interlocutory Appeals, By Fortune 500 Headquarters

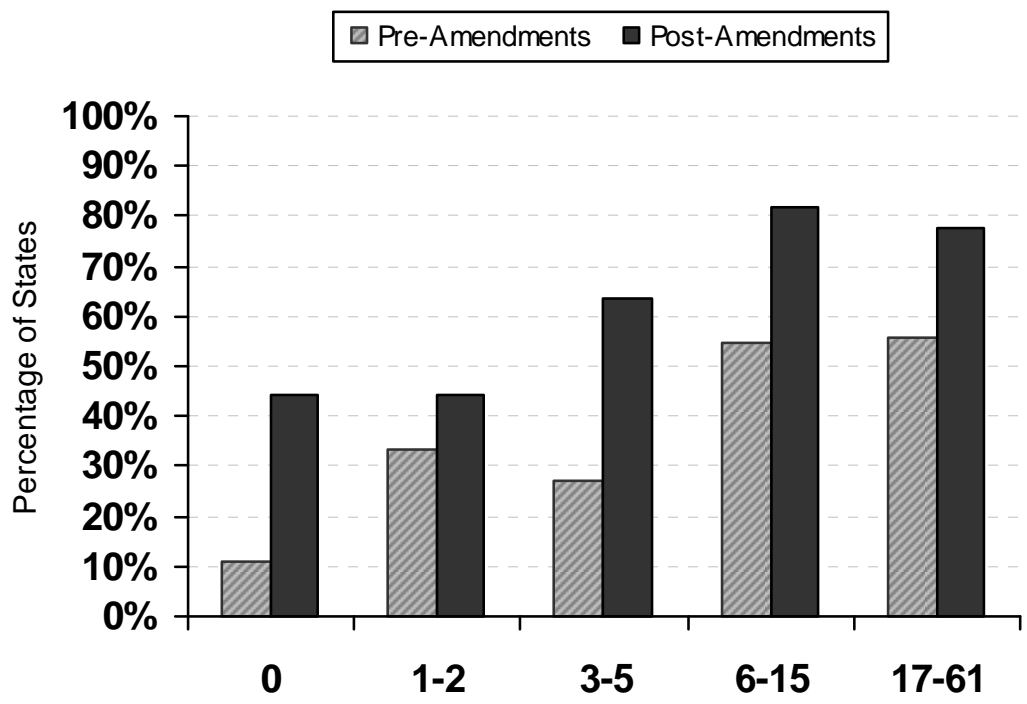

Number of Fortune 500 Headquarters in State

Figure 15 presents the percentage of states in each quintile that permitted expanded appellate opportunities for class litigants pre-Rule 23(f) and those that do so today. Here, one can see a more significant rise in expansive class appellate rules as the number of Fortune 500 headquarters in each state rises, and that upward curve is apparent both pre-Rule 23(f) and post-Rule 23(f). The percentage of states with expanded appellate access increases pre-Rule $23(\mathrm{f})$ from $11 \%$ to $56 \%$ as one moves from lowest to highest concentrations of Fortune 500 headquarters and from $44 \%$ to $78 \%$ along that axis post-Rule 23(f) (with a high of $82 \%$ in the second highest quintile). Post-Rule 23(f), in other words, states with the least number of Fortune 500 headquarters provide expanded class appellate rules at a lower rate than the overall average (61\%), while states in the middle range provide slightly higher than the average and a significantly higher than average percentages of states (78\% to $82 \%$ ) in the two highest quintiles, with six to sixty-one Fortune 500 headquarters.

These data are consistent with the Interest Group Theory, suggesting a correlation between a state's number of Fortune 500 corporate headquarters and its likelihood of providing appellate access for class defendants: fewer states with low numbers of Fortune 500 headquarters permit expanded opportunities for appellate review, while relatively 
more states do so when they are home to higher numbers of Fortune 500 headquarters. One complicating factor in this analysis is that the effect we see in Figure 15 may be explained by state population rather than the relative concentration of Fortune 500 corporations.

To determine whether the Fortune 500 data largely reflect relative population density, I once again divided the states into quintiles ${ }^{242}$ for analysis using 1998 population data provided by the United States Census Bureau. ${ }^{243}$

Figure 16: States With Limited Interlocutory Appeals That Amended, By Population

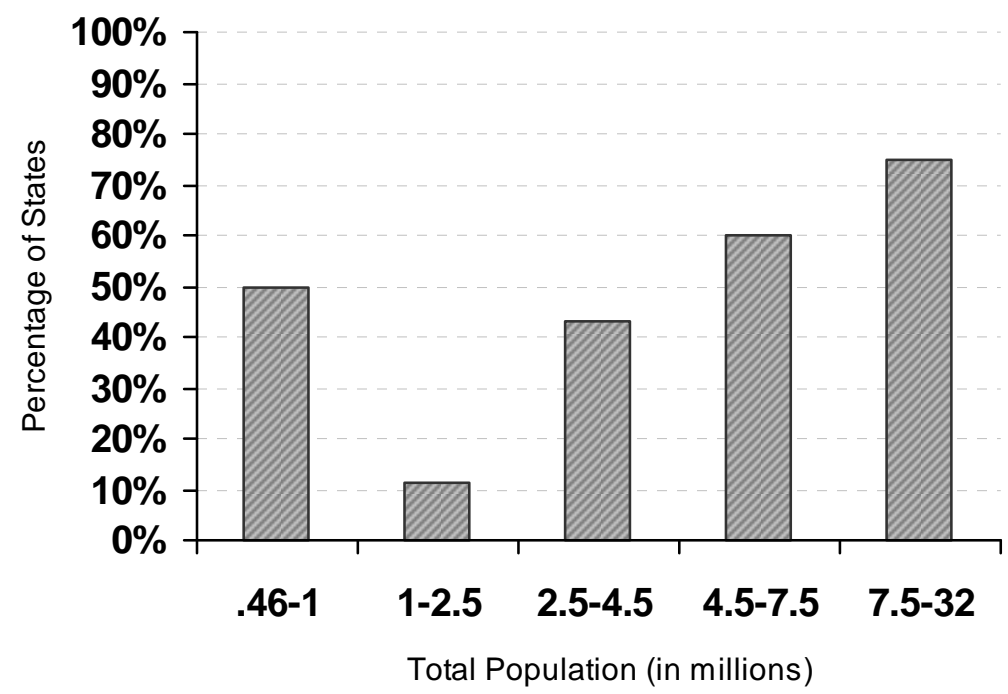

Figure 16 shows the percentage of states that amended class action appellate rules in the wake of Rule 23(f) for each of the five population quintiles. The upward curve here is even more marked than in Figure 14 (analyzing the percentage of amending states in each Fortune 500 quintile). The glaring exception to that pattern, however, can be seen in the first population quintile, which shows a $50 \%$ amendment rate among states with the smallest populations. That amendment percentage, higher

242. Here, however, I was able to break the forty-nine jurisdictions into four groups of ten and one group of nine.

243. See U.S. Census Bureau, State Population Estimates and Demographic Components of Population Change: July 1, 1998 to July 1, 1999, http://www.census.gov/popest/archives/ 1990s/ST99-01.txt (last visited April 22, 2010). 
than the overall average of $40 \%$, is higher than the next quintile of states and even slightly higher than the percentage of amending states in the third quintile.

Figure 17: Availability of Interlocutory Appeals, By Population

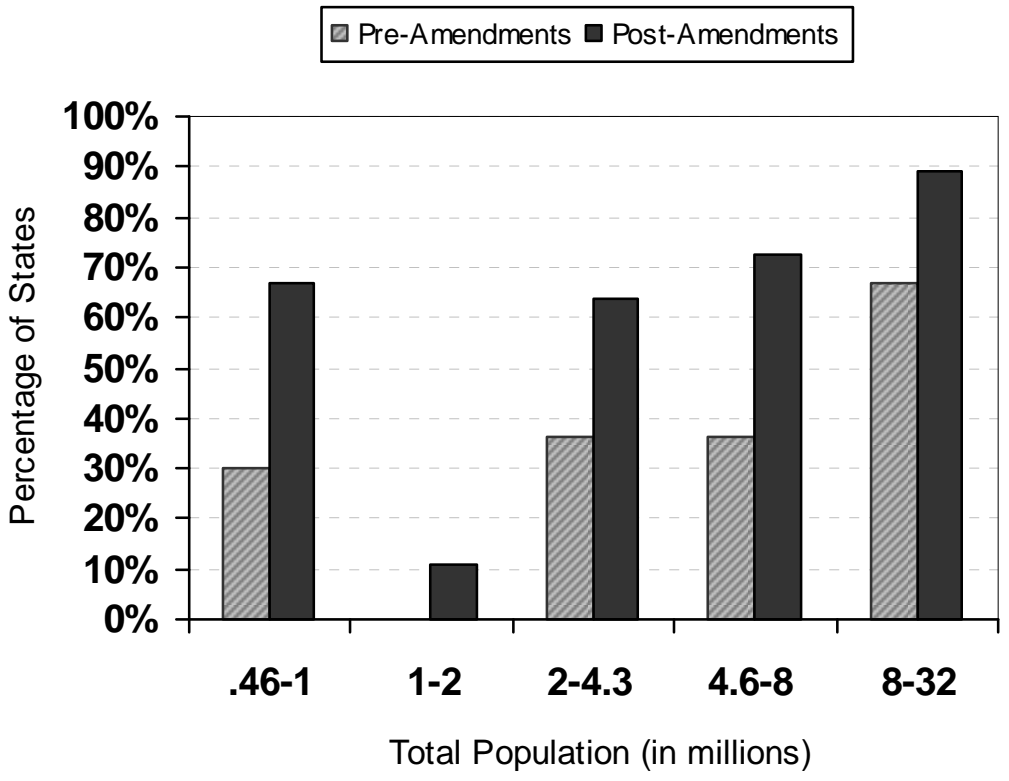

Figure 17, which presents the pre- and post-Rule 23(f) percentage of states in each population quintile providing expanded class appellate rules, reveals a pattern similar to that seen in Figure 16 both before and after Rule 23(f). Again, the marked staircase increases in percentages of states providing expanded class appellate access can be observed from the second through the fifth quintiles, with the lowest percentages of amending states found in the second quintile and the highest in the fifth. But, the first quintile of low population states breaks the pattern as it did in Figure 16, showing that $30 \%$ of states in that population quintile provided expanded appellate opportunities for class litigants even before Rule $23(f)^{244}$ and $66 \%$ of states did so post-Rule 23(f), again higher percentages than in either the second or the third quintiles.

244. This pre-Rule 23(f) level of expanded class appeals undermines any replica theory explanation for these low population states, given that the federal rules did not allow expanded appeals before Rule 23(f). One of these states, however, North Dakota, provided expanded appeals because of its adoption of a NCCUSL Model Class Action Act, evidencing a different kind of "replica" incentives but low-cost rulemaking all the same. See supra notes 197-98. 
The population data in Figure 16, then, reflects a fairly strong correlation between high populations and the likelihood of expanding class action appellate rules, with the exception of the relatively high percentage of amending states found among those states with the very lowest populations. I believe that this latter phenomenon can best be explained not as seriously undermining evidence of the Interest Group Theory, but rather as evidence of the unrelated correlation, discussed supra, between low population states and their relatively higher likelihood of federal rule replication. ${ }^{245}$

Does the population data undermine the Interest Group Theory explanation for state behavior? I am inclined to think not, but rather that the presence of interest groups with sufficient stakes to influence state class action rules simply becomes more likely and more powerful among more highly populous states. In other words, the Interest Group Theory effect may still be at play, but the number of Fortune 500 corporate headquarters is not the only (or perhaps even the most reliable) measure of interest group influences. Highly populous states are simply more likely to have more interest groups with incentives to influence the rulemaking processes. ${ }^{246}$

\section{Method of Judicial Selection}

A final test for measuring possible Interest Group Theory explanations of state amendment activity is the manner in which states select their supreme court justices, given that rulemaking authority rests in many states at least in part (if not exclusively) in their supreme courts. $^{247}$ Much has been written about one of the most important differences between federal and state courts - the phenomenon of elected

245. See supra notes 163-65 and accompanying text.

246. One might even argue that the Interest Group Theory supports (at least in part) the high rate of amending states and the extent of expanded class appellate rules among states with the lowest populations. On the one hand, one would have predicted that such states have insufficient populations (or corporate headquarters) to warrant the rulemaking influences of interest groups. But on the other hand, interest groups in those states might more readily (or more cheaply) succeed in exerting pressures on rulemaking entities. Interest groups might apply a cost-benefit analysis to determine which states to lobby, devoting greater resources to states with higher populations (and higher numbers of in-state corporate defendants) and fewer resources in states with relatively smaller populations, which explains much of what can be seen in Figures 16 and 17. Interest groups might, however, also have rational incentives to lobby in states with the smallest populations because the relatively low costs associated with such efforts may be well worth the benefits to be gained.

247. See, e.g., Jeffrey A. Parness \& Christopher C. Manthey, Public Process and State Judicial Rulemaking, 1 PACE L. REV. 121, 125-30 (1980) (discussing nature of state rulemaking procedures and the role of state legislative review). 
rather than appointed judges. ${ }^{248}$ Unlike federal judges appointed with lifetime tenure, ${ }^{249}$ some commentators have argued, elected state judges likely will be far more attuned to the political implications of their actions. ${ }^{250}$ They may also be more vulnerable to the influence of interest groups who can either contribute to the judicial campaigns of favored justices or devote their resources to targeting disfavored justices for defeat. $^{251}$

In those states in which supreme court justices are elected, the Interest Group Theory would hypothesize that campaign contributions or political pressures result in a higher incidence of rulemaking activity favoring certain factions. Such interest group pressure on state supreme court rulemakers might, therefore, help to explain which states adopted expansive interlocutory class action appellate rules. ${ }^{252}$ The Interest Group Theory suggests that a state with elected members of its supreme court would be more likely than a state with an appointed supreme court

248. See, e.g., RUNNing FOR Judge: The Rising Political, FinANCIAL, AND Legal StAKes OF Judicial ElECTIONS 11-13 (Matthew J. Streb ed. 2007); Alexander Tabarrok \& Eric Helland, Court Politics: The Political Economy of Tort Awards, 42 J.L. \& ECON. 157, 158 (1999) (comparing the political constraints faced by federal judges appointed for life and state judges, some of whom secure their positions "in partisan elections that are every bit as competitive as those for local political office").

249. See, e.g., Linda S. Mullenix, Hope Over Experience: Mandatory Informal Discovery and the Politics of Rulemaking, 69 N.C. L. REv. 795, 801-02 (1990) (noting that while the federal rulemaking process may be "painfully slow, deliberative, and dull," the federal judges that serve on the Civil Rules Advisory Committee "have little incentive to bend to political will"). But see Jeffrey W. Stempel, Politics and Sociology in Federal Civil Rulemaking: Errors of Scope, 52 ALA. L. Rev. 529, 613 (2001) (contending that the Advisory Committee has become increasingly subject to political pressures, "particularly [in its] receptiveness to certain arguments preferred by [defenseoriented law and business] groups"); Macey, supra note 7, at 646 (observing that federal judges "have not captured the rule-making process completely," as "other interest groups ... inevitably influence the process").

250. See, e.g., Tabarrok \& Helland, supra note 248, at 157-62 (arguing that campaign contributions result in judicial bias and higher tort damage awards).

251. See, e.g., Deborah Goldberg et Al., The New Politics of Judicial Elections 2004 vi (Jesse Rutledge ed., 2004) (warning that "[a] perfect storm of hardball TV ads, millions in campaign contributions and bare-knuckled special interest politics is descending on a growing number of Supreme Court campaigns”); Deborah Goldberg, Interest Group Participation in Judicial Elections, in RUNNING FOR JUDGE, supra note 248, at 73, 80-83 (describing tort reform as the "principal motivating force" that is "driving the intensifying interest group involvement in judicial elections over the past three cycles”); cf. Melinda Gann Hall, State Supreme Courts in American Democracy: Probing the Myths of Judicial Reform, 95 AM. POL. SCI. REV. 317, 317-19 (2001) (concluding that judges in partisan elections are more likely to be defeated than those in nonpartisan or retention elections).

252. Cf. Anthony Champagne, Interest Groups and Judicial Elections, 34 LOY. L.A. L. REv. 1391, 1397-98 (2001) (describing Ohio, Illinois, Michigan, and Alabama, which select their supreme court justices by partisan elections, as the sites of "hotly contested court battles having extensive interest group involvement”). 
to adopt a class action appellate rule much desired by defendant corporations. ${ }^{253}$

There are many limits to this measure of the Interest Group Theory. First, there may be little empirical evidence of a "link between political contributions and judicial behavior."254 Second, a justice's procedural rulemaking decisions are surely less likely than substantive rulings to motivate interest group pressures, even assuming that an elected justice may be influenced by interest group pressure at all. Third, states that failed to adopt expansive class action appellate rules might have been motivated not by the inaction of defense-oriented interest groups but rather the more persuasive lobbying of plaintiff-oriented interest groups ${ }^{255}$ so the absence of amendment activity might prove rather than disprove the theory but in ways that may be difficult to identify. Finally, in a number of states, appellate rule amendment activity can take place in either the judicial branch or in the legislative branch. ${ }^{256}$ This phenomenon seriously complicates the task of attempting to detect whether political pressure by interest groups (if any) occurred more often in states with elected justices or occurred primarily in state legislatures, which renders a state's method of state supreme court judicial selection

253. Even states that appoint justices to their supreme courts on a facially merit-driven basis often include in their appointment processes either a state bar nominating committee or a legislative confirmation requirement, both of which may introduce similar interest group influences as found in states with elected justices. See Stephen J. Ware, The Missouri Plan in National Perspective, 74 Mo. L. REV. 751, 752-58 (2009) (examining “democratic” judicial selection methods that include senate confirmation, compared to more "elitist" selection processes allowing nominating influence by members of the state bar).

254. See Richard A. Nagareda, Class Actions in the Administrative State: Kalven and Rosenfeld Revisited, 75 U. CHI. L. REV. 603, 612 (2008) ("It bears emphasis that empirical research has yet to explore systematically the relationship, if any, between class certification and the involvement in state judicial elections of interest groups-whether the local plaintiffs' bar or business-side interests-for whom such rulings might well be a major topic of concern.”); see also Stephen J. Choi, G. Mitu Gulati, \& Eric A. Posner, Professionals or Politicians: The Uncertain Empirical Case for an Elected Rather Than Appointed Judiciary, J.L. ECON. \& ORG. (Articles in Advance published online on Nov. 5, 2008) (casting empirical doubt on conventional wisdom that appointed judges exercise greater independence than elected judges). But see Tabarrok \& Helland, supra note 248, at 157-62.

255. See, e.g., Anthony Champagne, Tort Reform and Judicial Selection, 38 LOY. L.A. L. REV. 1483, 1488 (2004) (noting that in state judicial election battles, "trial lawyers and unions . . . tend to promote the candidacies of plaintiff-friendly judges”); Adam Liptak, The Worst Courts for Businesses? It's a Matter of Opinion, N.Y. TIMES, Dec. 24, 2007, at A10 (quoting a prominent class action plaintiffs' attorney who referred to plaintiff-friendly venues as “'magic jurisdictions"” where "“the judiciary is elected with verdict money"”).

256. See, e.g., Donna J. Pugh et AL., JudiCial RulEMAKING: A Compendium V (1984); Parness \& Manthey, supra note 247, at 128-30; Charles W. Grau, Who Rules the Courts? The Issue of Access to the Rulemaking Process, 62 JudiCATuRe 428, 428 (1979); Allan Ashman, Measuring the Judicial Rule-Making Power, 59 JudICATURE 215, 215-16 (1975). 
far less significant as a predictive measure of the likelihood a state will adopt an expansive class action appellate rule. ${ }^{257}$

To determine how the states select their supreme court justices, I reviewed data collected by the American Judicature Society. ${ }^{258}$ Figure 18 presents three categories of judicial selection: appointment, nonpartisan election and partisan election. The Interest Theory would suggest that states that select supreme court justices by partisan elections would be more likely than states with appointed supreme court justices to be influenced by interest group pressure to promulgate rules that favor those interest groups, such as expanded appellate access for class action defendants.

257. One scholar has argued that judges who promulgate rules of procedure are also strongly motivated by their own "rational self-interest," which usually includes-but sometimes conflicts with—rules that promote efficiency. Macey, supra note 7, at 627. The self-interest of state supreme court judges in adopting rules that expand appellate authority over class certification decisions, then, might include a desire to play a more prominent role in the development of this hotly contested area of law. Cf. id. at 642-43 (noting federal appellate judges' opposition to the creation of a new appellate court between the Supreme Court and existing courts of appeals because "reducing the caseload of the Supreme Court" would be achieved at the cost of reducing "the prestige of the lower federal courts of appeals"). If that aspect of appellate court self-interest indeed exists, of course, it would presumably be present irrespective of the process by which members of a state's supreme court are selected.

258. See American Judicature Society, Judicial SELEction in the States: Appellate AND GENERAL JURISDICTION COURTS (2010), http://www.judicialselection.us/uploads/documents /Judicial_Selection_Charts_1196376173077.pdf (last visited March 24, 2010). I looked only at the selection method for each state's supreme court justices, rather than lower court judges, and I combined the data for all states that utilized various judicial appointment methodologies (gubernatorial or legislative appointment, selection through a bar nominating committee, etc.). 
Figure 18: States With Limited Interlocutory Appeals That Amended, By Judicial Selection Method

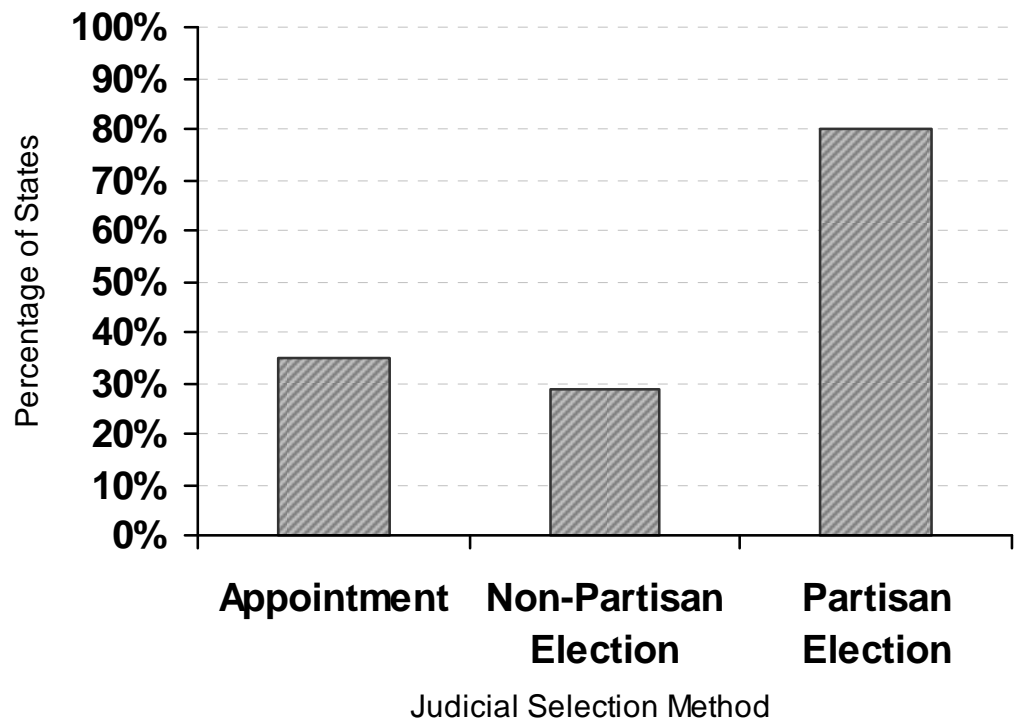

Apparently supportive of this Interest Group Theory hypothesis, Figure 18 shows that among states that elect their supreme court justices through partisan elections, $80 \%$ of states that previously limited class action appeals amended post-Rule 23(f) to expand class litigant appellate access. This rate is significantly higher than either the $29 \%$ of states that select supreme court justices by non-partisan elections or the $35 \%$ of states that appoint members of their supreme courts. Half of the states with partisan supreme court elections that amended their class appellate rules post-Rule 23(f), however, did so by legislative means rather than by judicial rulemaking. ${ }^{259}$

259. Specifically, Alabama and Ohio enacted expanded class action appellate rules by statute while Illinois and New Mexico did so by Supreme Court rulemaking. See supra notes 90, 97, 107, 111 and accompanying text. 
Figure 19: Availability of Interlocutory Appeal, By Judicial Selection Method

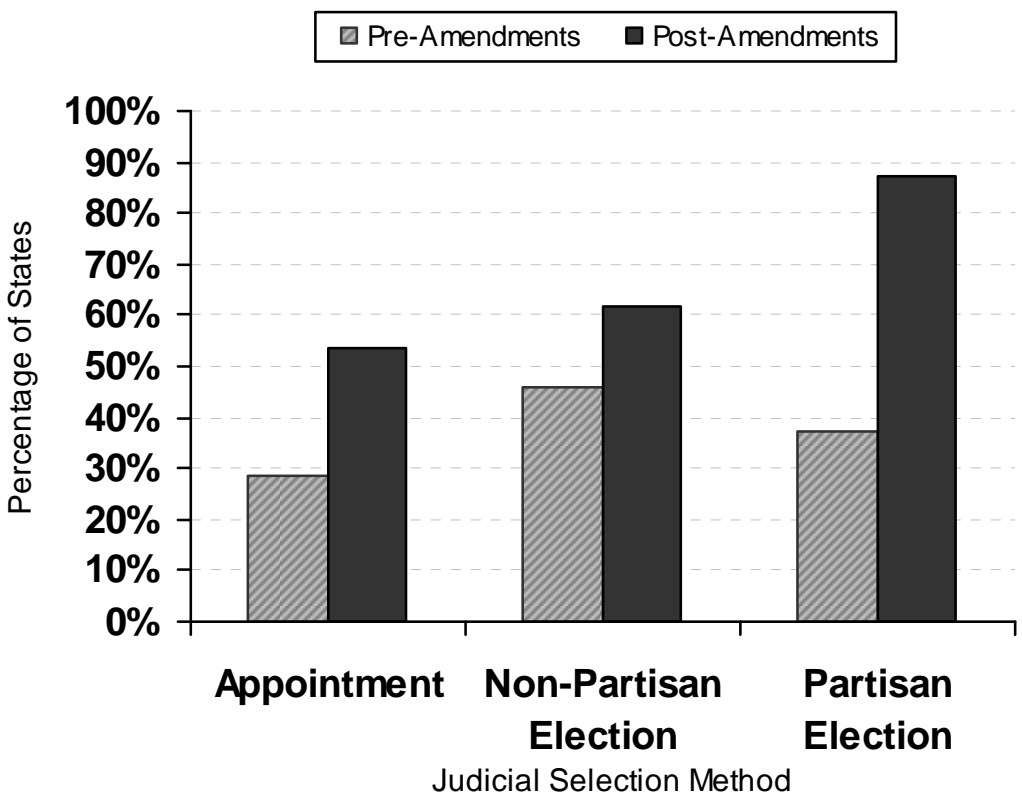

Figure 19 reveals that pre-Rule 23(f), states with non-partisan elected supreme court justices were somewhat more likely than either of the other judicial selection categories to already provide expanded access to class litigants: $46 \%$ of states with non-partisan elected justices compared to $29 \%$ of states with appointed justices and $37.5 \%$ of partisan elected justices. Post-Rule 23(f), however, $87.5 \%$ of states with partisan elections provided expanded class appellate rules, compared to $61.5 \%$ of states with non-partisan elections and $54 \%$ of states with appointed supreme courts.

The numbers are small and, as cautioned above, it is quite difficult to single out this factor given several complicating factors: rulemaking authority shared between legislative and judicial branches, the potential for interest group pressure even among those states that appoint members of their Supreme Courts, and the potential for interest group pressures on both sides of the issue such that the absence of a rule expanding appellate access might mean either the presence of strong interest group opposition to such a rule or simply the absence of interest group influence altogether. Indeed, the fact that half of the states with partisan elections that amended their class action rules did so by legislative rather than judicial rulemaking materially undercuts the apparent evidence of a 
strong Interest Group Theory effect among states with partisan elected Supreme Court justices.

\section{CONCLUSION}

Rule 23(f) undoubtedly played a powerful role in state rulemaking decisions, as readily can be seen in the $40 \%$ of states that amended their limited class appeals rules post-Rule 23(f) to expand appellate opportunities. But the data observed above suggest that those changes cannot solely be explained in terms of pure mirroring behavior, although some such replica effects likely took place. The influence of affected interest groups muscling their way into state rulemaking processes appears in important part to explain the state changes that occurred, as well.

As we saw in some of the anecdotal state evidence in Part III, influence group pressure to enact class action reforms such as this one may have been exercised as part of broader state tort reform efforts, although the best available state tort reform data does not appear to support such a correlation. The high stakes world of class actions, however, clearly motivates both proponents and opponents of class actions to seek every possible strategic advantage. Post-Rule 23(f), interest groups opposed to class actions had strong incentives to ensure that state class action rules at least provided discretionary appeals equivalent to Rule 23(f). If a state's class action rule limited a defendant's ability to seek interlocutory appeal of a class certification order, class plaintiffs' attorneys might elect to file in that state court forum rather than in an available federal forum. Prior to CAFA, a defendant might have been unable to remove such an action to a federal court that provided greater access to appellate scrutiny of a certified class.

Post-CAFA, of course, most multi-state class actions may be removed to federal court, but CAFA's jurisdictional exceptions continue to provide enormous incentives for corporate defendants to lobby for class action appellate rules in their home states that at least provide discretionary appeals. If such in-state corporate defendants cannot remove state court class actions due to CAFA's jurisdictional carve-outs, they will therefore likely lobby for state class appellate rules that equal those they now have in federal court or push for even greater appellate access than that provided under federal Rule 23(f). The data on Fortune 500 corporate headquarters appear to bear out that hypothesis, as does the data on perceived class action "hot states": in states in which corporate interest groups have greater incentives to pursue rules 
providing greater opportunities to challenge class certification orders, we find higher rates of expanded appellate rules for class litigants.

Rule 23(f) may have jump-started the phenomenon of state class action appellate rule changes, but interest group muscle appears to best explain much of that rulemaking behavior. In states with little apparent class action activity or few large in-state corporations, the rule changes observed more likely reflect a continuing pattern of low-cost federal rule mirroring. 